\title{
Hydrotreater/Distillation Column Hazard Analysis Report
}

Rev. 2

April 2016

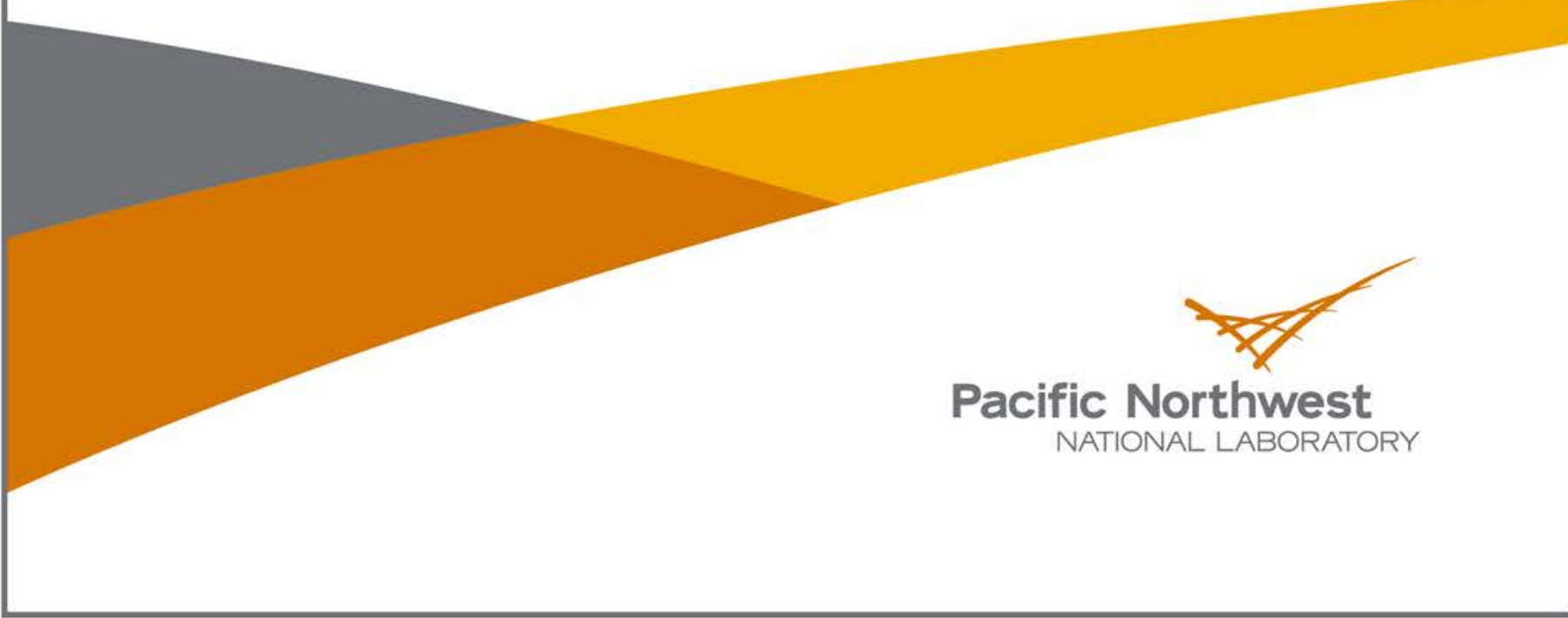




\title{
DISCLAIMER
}

This report was prepared as an account of work sponsored by an agency of the United States Government. Neither the United States Government nor any agency thereof, nor Battelle Memorial Institute, nor any of their employees, makes any warranty, express or implied, or assumes any legal liability or responsibility for the accu racy, completeness, or usefulness of any information, apparatus, product, or process disclosed, or represents that its use would not infringe privately owned rights. Reference herein to any specific commercial product, process, or service by trade name, trademark, manufacturer, or otherwise does not necessarily constitute or imply its endorsement, recommendation, or favoring by the United States Government or any agency thereof, or Battelle Memorial Institute. The views and opinions of authors expressed herein do not necessarily state or reflect those of the United States Government or any agency thereof.

\author{
PACIFIC NORTHWEST NATIONAL LABORATORY \\ operated by \\ BATTELLE \\ for the \\ UNITED STATES DEPARTMENT OF ENERGY \\ under Contract DE-AC05-76RL01830
}

Printed in the United States of America

Available to DOE and DOE contractors from the

Office of Scientific and Technical Information,

P.O. Box 62, Oak Ridge, TN 37831-0062;

ph: (865) 576-8401

fax: $(865) 576-5728$

email: reports@adonis.osti.gov

Available to the public from the National Technical Information Service

5301 Shawnee Rd., Alexandria, VA 22312

ph: (800) 553-NTIS (6847)

email: orders $a$ ntis.gov <http://www.ntis.gov/about/form.aspx>

Online ordering: http://www.ntis.gov

से This document was printed on recycled paper

(8/2010) 
Hydrotreater/Distillation Column Hazard Analysis Report

\begin{tabular}{||l|l|l||}
\hline \hline $\begin{array}{l}\text { Revision } \\
\text { Number }\end{array}$ & Effective Date & Description of Change \\
\hline 0 & $11 / 2012$ & Initial issue. \\
\hline 1 & $12 / 14 / 2015$ & $\begin{array}{l}\text { Update to reflect changes in procedures; clarification of HTDC } \\
\text { processes; clarification of controls; BLEVE and PVB } \\
\text { calculations updated. }\end{array}$ \\
\hline 2 & $4 / 8 / 2016$ & $\begin{array}{l}\text { Update to remove pressure interlocks as critical controls (see } \\
\text { HTDC-2016-023 and HTDC-2016-026); clarification that } \\
\text { attached drawings are subject to change. }\end{array}$ \\
\hline & & \\
\hline & & \\
\hline & & \\
\hline
\end{tabular}


Prepared by: Peter Lowry

Katie Wagner





Hydrotreater and Distillation Column Project

Approved by:



$\frac{4 / 11 / 16}{\text { Date }}$ 
Hydrotreater/Distillation Column Hazard Analysis Report

This page intentionally left blank

Page iii 


\section{Executive Summary}

This project Hazard and Risk Analysis Report contains the results of several hazard analyses and risk assessments. An initial assessment was conducted in 2012, which included a multi-step approach ranging from design reviews to a formal What-If hazard analysis. A second What-If hazard analysis was completed during February 2013 to evaluate the operation of the hydrotreater/distillation column processes to be installed in a process enclosure within the Process Development Laboratory West (PDL-West) facility located on the PNNL campus. The qualitative analysis included participation of project and operations personnel and applicable subject matter experts. The analysis identified potential hazardous scenarios, each based on an initiating event coupled with a postulated upset condition. The unmitigated consequences of each hazardous scenario were generally characterized as a process upset; the exposure of personnel to steam, vapors or hazardous material; a spray or spill of hazardous material; the creation of a flammable atmosphere; or an energetic release from a pressure boundary.

In response to independent review comments received by PNNL from PNSO, two supplemental hazard analyses were conducted and quantitative risk assessments performed for the Distillation Column and Hydrotreater units in June 2014 and April 2015, respectively (see Appendices D and E). As described below, selected hazardous scenarios received increased attention:

- For scenarios involving a release of hazardous material or energy, controls were identified in the What-If analysis table that either prevent the occurrence or mitigate the effects of the release.

- For scenarios with significant consequences that could impact personnel outside the enclosure, "critical controls" were identified in the What-If analysis table that either prevent the occurrence or mitigate the effects of the release.

- For events requiring critical controls (highly energetic releases and potential deflagrations), quantitative analyses were performed to determine the potential magnitude of the scenario, including the potential to affect the environment outside of the PDL-West facility.

Only for the conservative unmitigated analysis involving a Boiling Liquid Expanding Vapor Explosion (BLEVE) of the reactor vessel (R-130) could a significant overpressure (greater than $21 \mathrm{kPa}$ ) challenging PDL-West facility structure occur. Calculations determined that there were no cases in which overpressures were sufficient to result in greater than minor damage $(7 \mathrm{kPa})$ at any of the normally occupied facilities outside of the PDL-West facility.

The following critical controls prevent these high-energy scenarios from occurring:

- Vessel and piping design, including pressure relief valves

- Hydrogen utility (supply) design

- Reactor and distillation column temperature and pressure controls

- Enclosure design and ventilation system

- Hydrogen and flammable vapor monitors and selected interlocks

- $\quad$ Safe Operating Procedures 


\section{Hydrotreater/Distillation Column Hazard Analysis Report}

The analysis concludes that with the identified hazard controls in place, the risks posed from operation of the hydrotreater and distillation columns are adequately mitigated, and these systems can be operated safely, consistent with PNNL control of other laboratory operations. 
Hydrotreater/Distillation Column Hazard Analysis Report

This page intentionally left blank 


\section{Table of Contents}

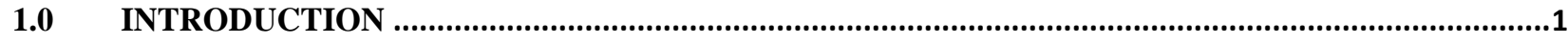

1.1 PURPOSE

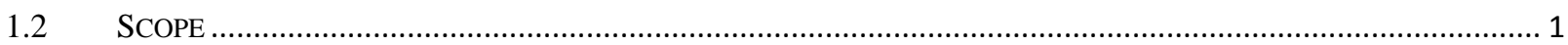

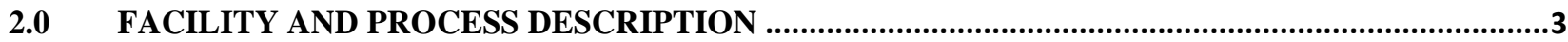

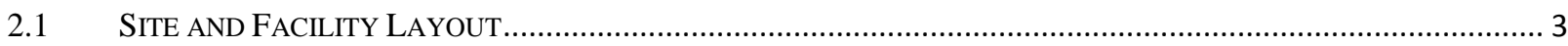





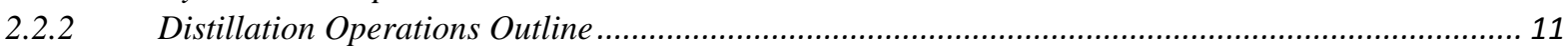

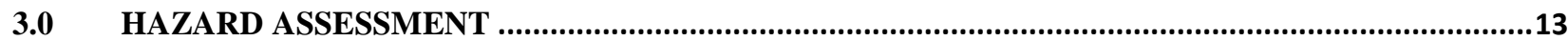



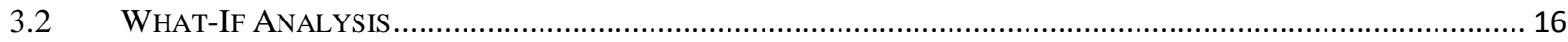

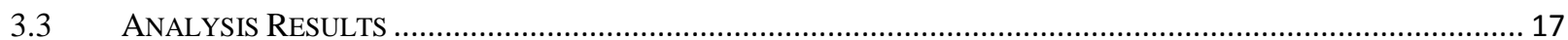

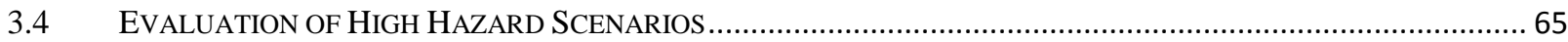





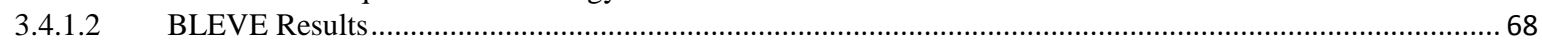

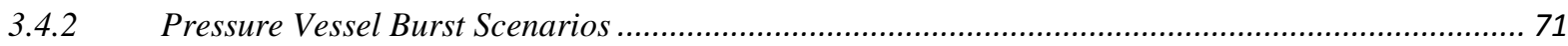



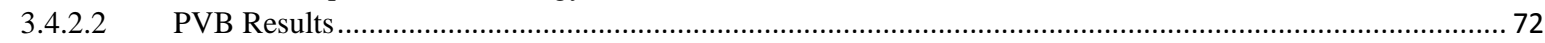

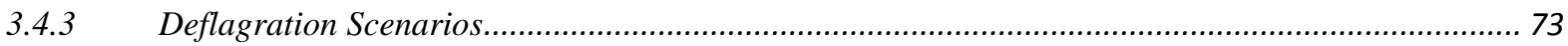

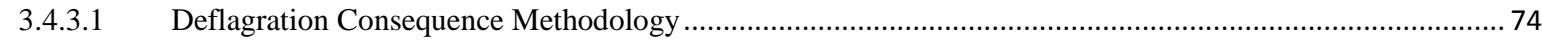

3.4.3.2 Deflagration Results........................................................................................................................ 74

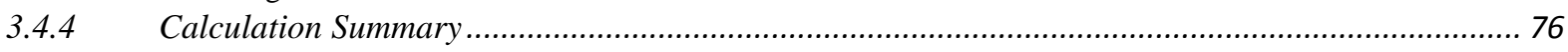

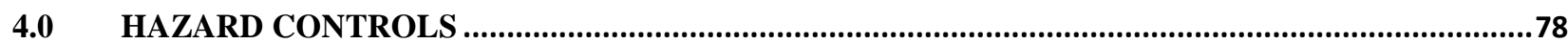

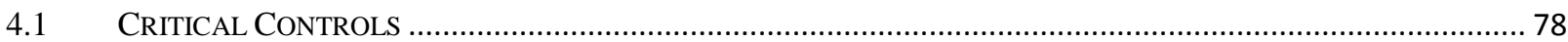

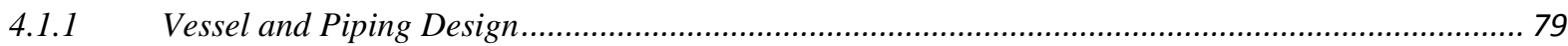

4.1.2 Reactor and Distillation Column Temperature Critical Controls .................................................... 80

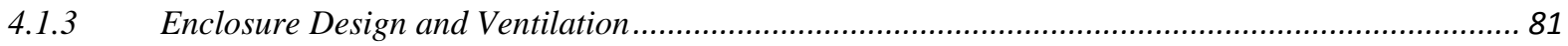



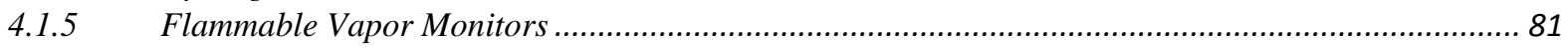

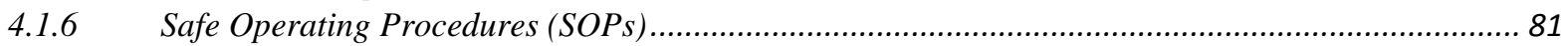

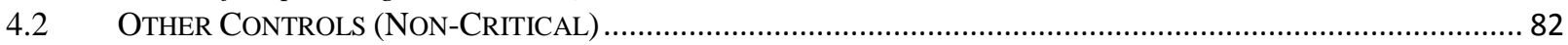

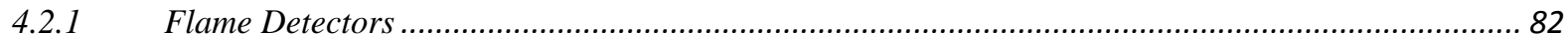

4.2.2 Fire Suppression System....................................................................................................... 82

4.2.3 Temperature and Pressure Controls/Alarms Prompting Operator Response ................................... 82

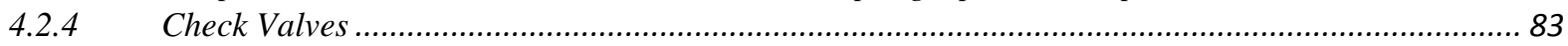



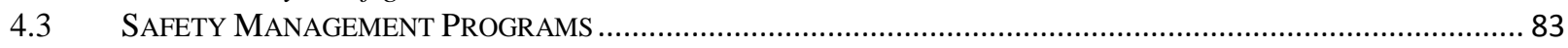

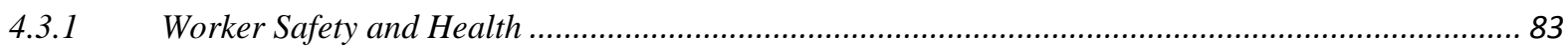

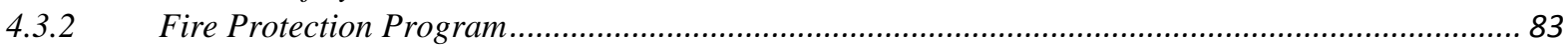

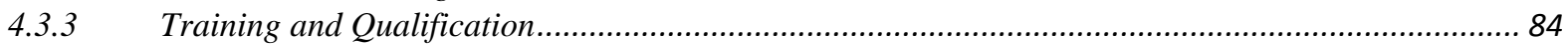

4.3.4 Maintenance and Testing Program .................................................................................... 84

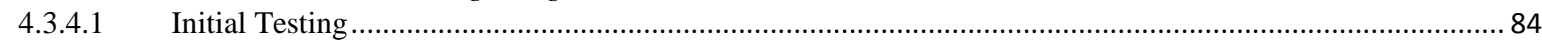

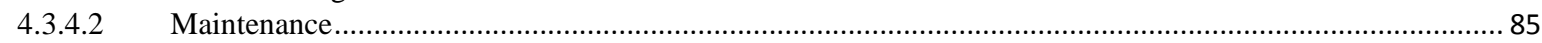



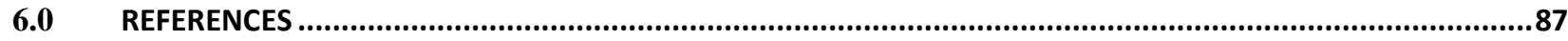

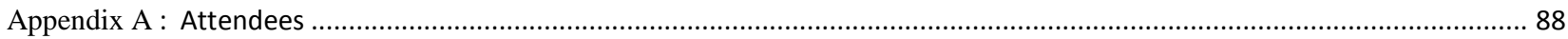

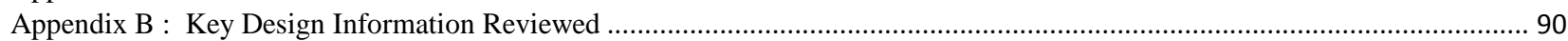




\section{Hydrotreater/Distillation Column Hazard Analysis Report}

Appendix C : November 2012 Hydrotreater / Distillation Column Project Hazard and Risk Analysis Report .............................. 93

Appendix D : Supplemental Hazard Analysis and Risk Assessment - Distillation Column ................................................... 95

Appendix E : Supplemental Hazard Analysis and Risk Assessment - Hydrotreater ............................................................. 97 
Hydrotreater/Distillation Column Hazard Analysis Report

This page intentionally left blank

Page ix 


\subsection{Introduction}

The hydrotreater/distillation column project consists of catalytic hydrotreatment (hydrotreater) and distillation processes to produce a range of desired petroleum products from fast pyrolysis bio-oil feedstock. The hydrotreater and distillation processes are being installed in a portion of the Process Development Laboratory West (PDL-West) facility located on the PNNL Campus.

\subsection{Purpose}

As part of the PNNL Integrated Safety Management process, the hazards associated with performing work within PNNL-managed facilities are identified and appropriate controls applied. The hazards associated with the hydrotreater/distillation column processes have been reviewed during design review meetings as part of the overall design process. In addition, facilitated hazard analysis sessions and quantitative risk assessments were performed. The purpose of this report is to document the hazards and controls associated with the process-related system components forming the hydrotreater/distillation column processes contained within the PDLWest facility and the potential interactions of these hazards with respect to supporting systems and the facility as evaluated during What-If hazard analysis sessions held in February 2013 and supplemental hazard analyses and risk assessments performed in 2014 and 2015 (Appendices D and $\mathrm{E})$.

\subsection{Scope}

The What-If hazard analysis used for the hydrotreater/distillation column project is consistent with the methodology found in the American Institute of Chemical Engineers (AIChE) Guidelines for Hazard Evaluation Procedures - With Worked Examples, $2^{\text {nd }}$ Edition [AIChE, 1992], and in Chemical Process Hazards Analysis [DOE-HDBK-1100-2004].

The scope of this assessment did not include evaluating those hazards that were considered normal and incidental to the operation of the PDL-West facility unless those hazards were judged to have the potential to challenge the safe operation of the hydrotreater/distillation column processes. These incidental hazards are adequately addressed through the Integrated Operations System (IOPS) and existing PNNL work controls.

Examination of the spectrum of potential upset conditions that could expose members of the public, onsite workers, facility workers, and the environment to hazardous materials and conditions is incorporated into this report. The hazard evaluation postulated scenarios involving both single-point/event failures and common-cause initiators. The upset conditions with the potential to result in highly energetic releases or potential deflagrations were evaluated using quantitative analysis to determine the potential magnitude of the scenario, including the potential to affect the environment outside of the PDL-West facility.

Section 2, Facility and Process Description, provides a brief description of the design and information to enable an understanding of the hazards associated with the hydrotreater/distillation column processes.

Section 3, Hazard Assessment, provides a summary of the What-If methodology used, description of the hazardous scenarios considered, and the results of the analysis. 
Section 4, Hazard Controls, describes the “critical controls” for the high consequence hazards and PNNL Safety Management Programs which support performing work safely. The critical controls are those required to prevent or mitigate significant consequences associated with the hydrotreater and distillation column process hazards. Other non-critical controls were included to further reduce hazardous event frequencies.

Appendices A and B contain the meeting participant information and design information reviewed during the hazards analysis meetings. The design documents in Appendix B are historical and subject to change. See the Hydrotreater/Distillation Column SharePoint site for current design documents.

Appendix C contains the November 2012 Hydrotreater / Distillation Column Project Hazard and Risk Analysis Report which described a number of appropriate controls that were, or are being, put in place to ensure the safe operation of the hydrotreater and distillation processes. The 2012 report will be retained as a static part of this hazard analysis; it will not be revised.

Appendices D and E contains the July 2014 and April 2015 Supplemental Hazard Analysis and Risk Assessment for the Distillation Column and Hydrotreater units. These reports were generated in response to independent review comments received by PNNL from the U.S. Department of Energy Pacific Northwest Site Office (PNSO) with regard to the Hydrotreater/Distillation Column Hazard Analysis Report issued in April 2013. 


\subsection{Facility and Process Description}

\subsection{Site and Facility Layout}

The hydrotreater/distillation column processes will be conducted in the PDL-West high bay work area in a dedicated process enclosure. The PDL-West building is located on the PNNL site in north Richland as shown in Figure 2-1.

Approximate distances from the hydrotreater/distillation column process enclosure to key landmarks are shown in Table 2-1.

Table 2-1. Distance from PDL-West to Surrounding Landmarks

\begin{tabular}{|c|c|c|c|}
\hline \multirow{2}{*}{ Landmark } & \multirow{2}{*}{ Direction } & \multicolumn{2}{|c|}{ Distance from Process Enclosure } \\
\hline & & feet & meters \\
\hline Process Development Laboratory East* & East & 116 & 35 \\
\hline $5^{\text {th }}$ Street & South & 120 & 37 \\
\hline Innovation Boulevard & West & 140 & 43 \\
\hline Chemical Engineering Laboratory & East & 175 & 53 \\
\hline Technical Support Warehouse & North & 290 & 88 \\
\hline $4^{\text {th }}$ Street & South & 420 & 128 \\
\hline Research Technology Laboratory & South East & 730 & 222 \\
\hline George Washington Way & East & 790 & 241 \\
\hline Atmospheric Measurement Laboratory & Northwest & 825 & 251 \\
\hline Inhalation Laboratory & Northeast & 880 & 268 \\
\hline KinderCare & West-Southwest & 1120 & 341 \\
\hline
\end{tabular}

*Nearest normally occupied Facility outside PDL-West, endpoint for the evaluation of impacts in Section 3.4. 


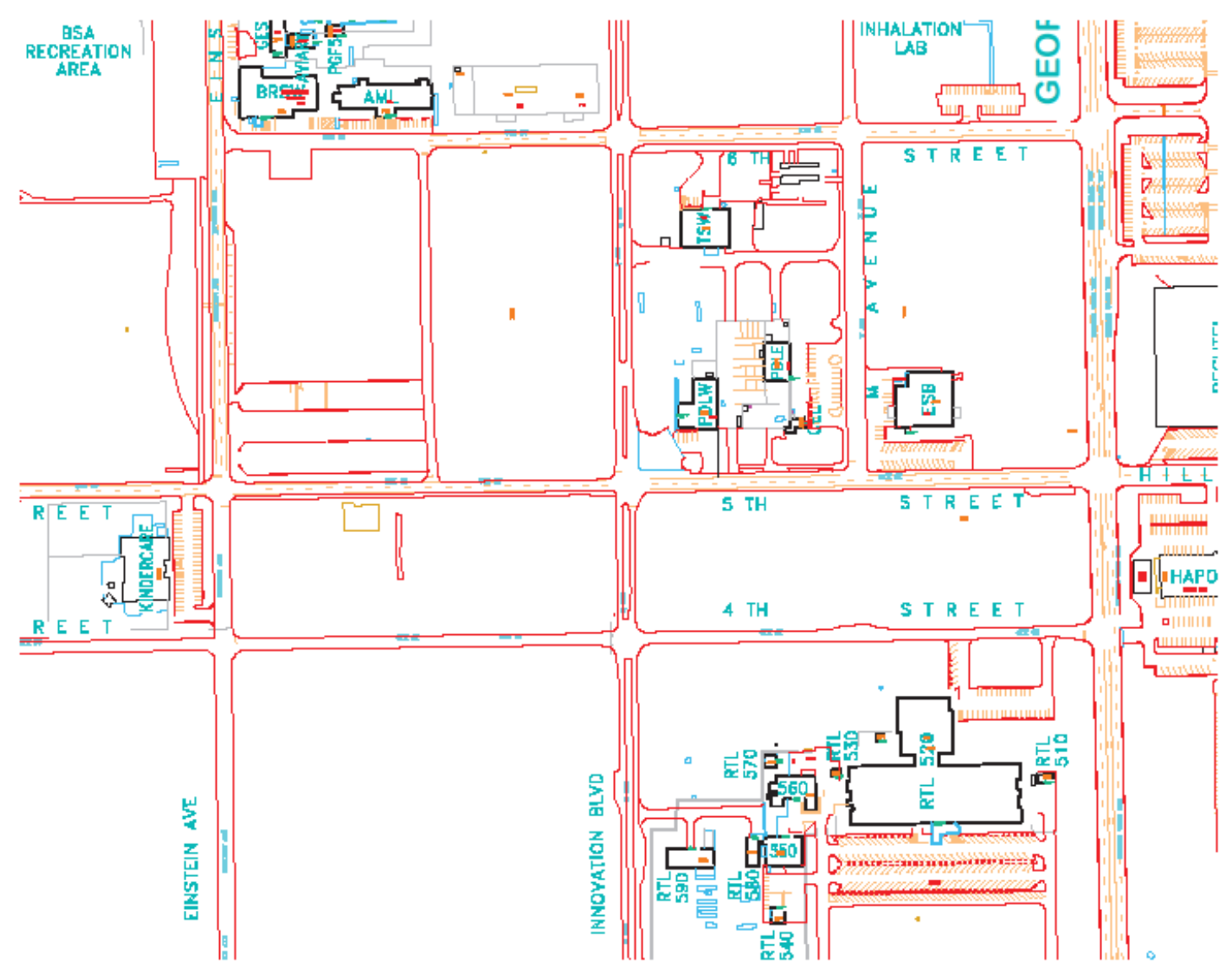

Figure 2-1. Location of PDL-West (PDLW) 


\subsection{Hydrotreater/Distillation Column Processes}

The hydrotreater/distillation column project consists of catalytic hydrotreatment (hydrotreater) and distillation processes to produce a range of desired petroleum products derived from fast pyrolysis bio-oil feedstock. Figure 2-2 depicts the process flow diagram for the hydrotreater and distillation processes. The planned operation duration and frequency are 1 week (five, 24-hour continuous operation days per month). The hydrotreater/distillation systems are located in a dedicated enclosure as shown in Figure 2-3. Figure 2-4 shows the major hydrotreater process equipment; Figure 2-5 shows the major distillation process equipment.

Hydrogen is supplied to the hydrotreater by a high pressure compressor, storage bottles (or tube trailer), and a distribution system. This system will also supply hydrogen to other research projects located near PDL-West. High and low pressure nitrogen will be supplied via a distribution system that is dedicated to the hydrotreater/distillation processes.

During hydrotreatment, deoxygenation of bio-oil takes place to produce hydrocarbon products that are similar to gasoline, diesel and jet fuel blendstock. Hydrotreatment is accomplished by adding hydrogen as feed along with the bio-oil in the presence of a catalyst. The process is typically operated at temperatures up to approximately $400^{\circ} \mathrm{C}$ and pressures up to approximately 135 atm. Distillation is then used to obtain the specific gasoline, diesel and jet fuel cuts from the hydrotreated product.

The hydrotreater consists of a down-flow trickle, fixed bed reactor with gas and liquid feed systems, liquid/gas product separation and recovery, and an instrumentation/control system. The system is designed for a 2.5 liter per hour bio-oil feed capacity at $400^{\circ} \mathrm{C}$ and 135 atm with hydrogen feed at $5 \mathrm{~m}^{3} / \mathrm{h}$. In addition, the distillation column will be used to fractionate the hydrocarbon product into gasoline, diesel, jet fuel, and cycle oil products. The distillation column can be, but is not planned to be, operated concurrent with the hydrotreater and is designed with a throughput of 7.5-15 liters of feed per hour. Both the hydrotreater and the distillation column are skid mounted with power distribution systems, transformers, outlets, wiring, panels, cooling, heating, control, and other ancillary process systems.

To support the hazards analysis, the key process steps for the hydrotreater/distillation operations were outlined and reviewed for in Section 2.2.1 and 2.2.2. 


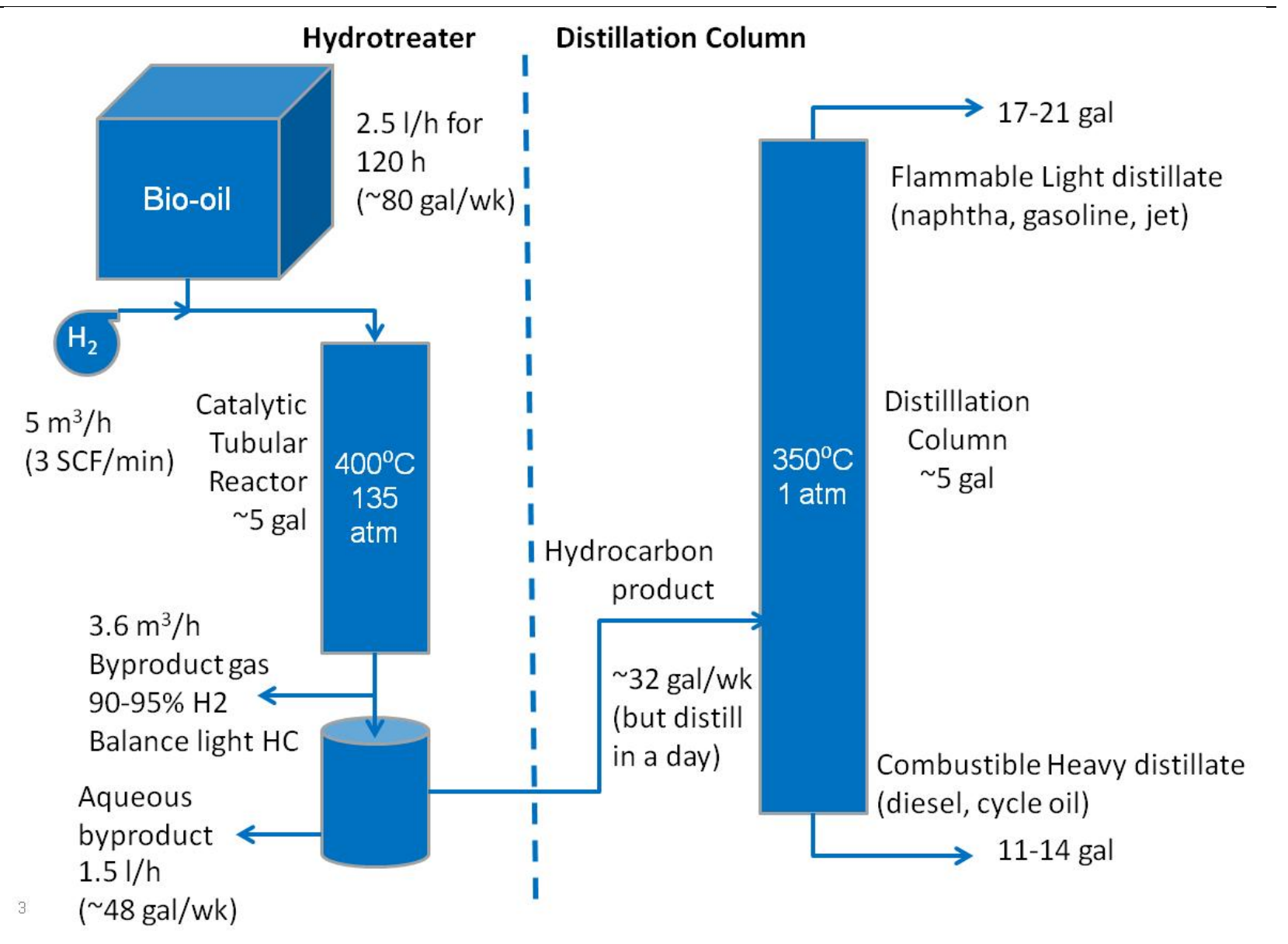

Figure 2-2. Hydrotreater/Distillation Process Flow Diagram 


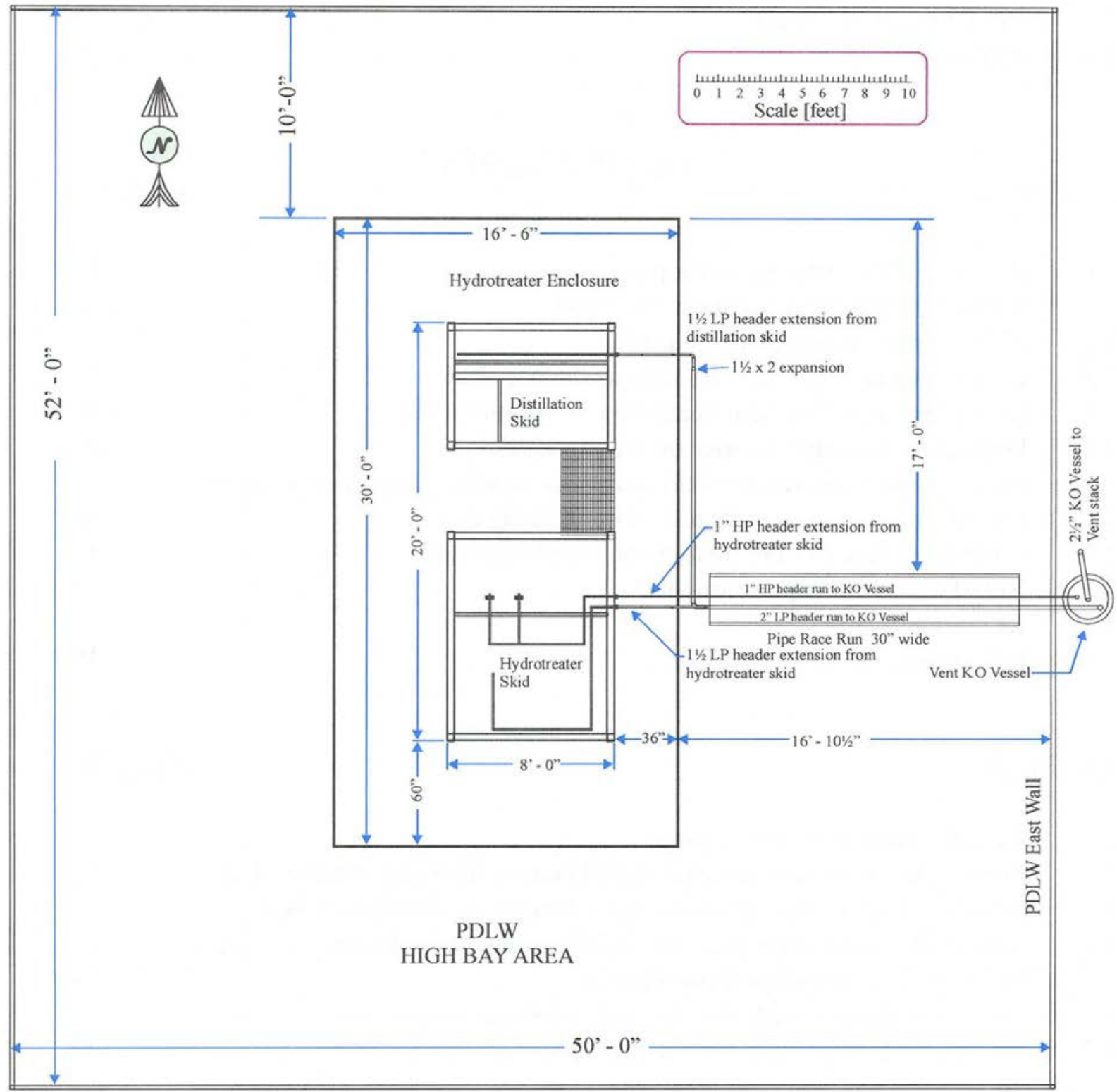

Figure 2-3. Location of Hydrotreater/Distillation Enclosure within PDL-West (from CTI-12-631) 
Hydrotreater/Distillation Column Hazard Analysis Report

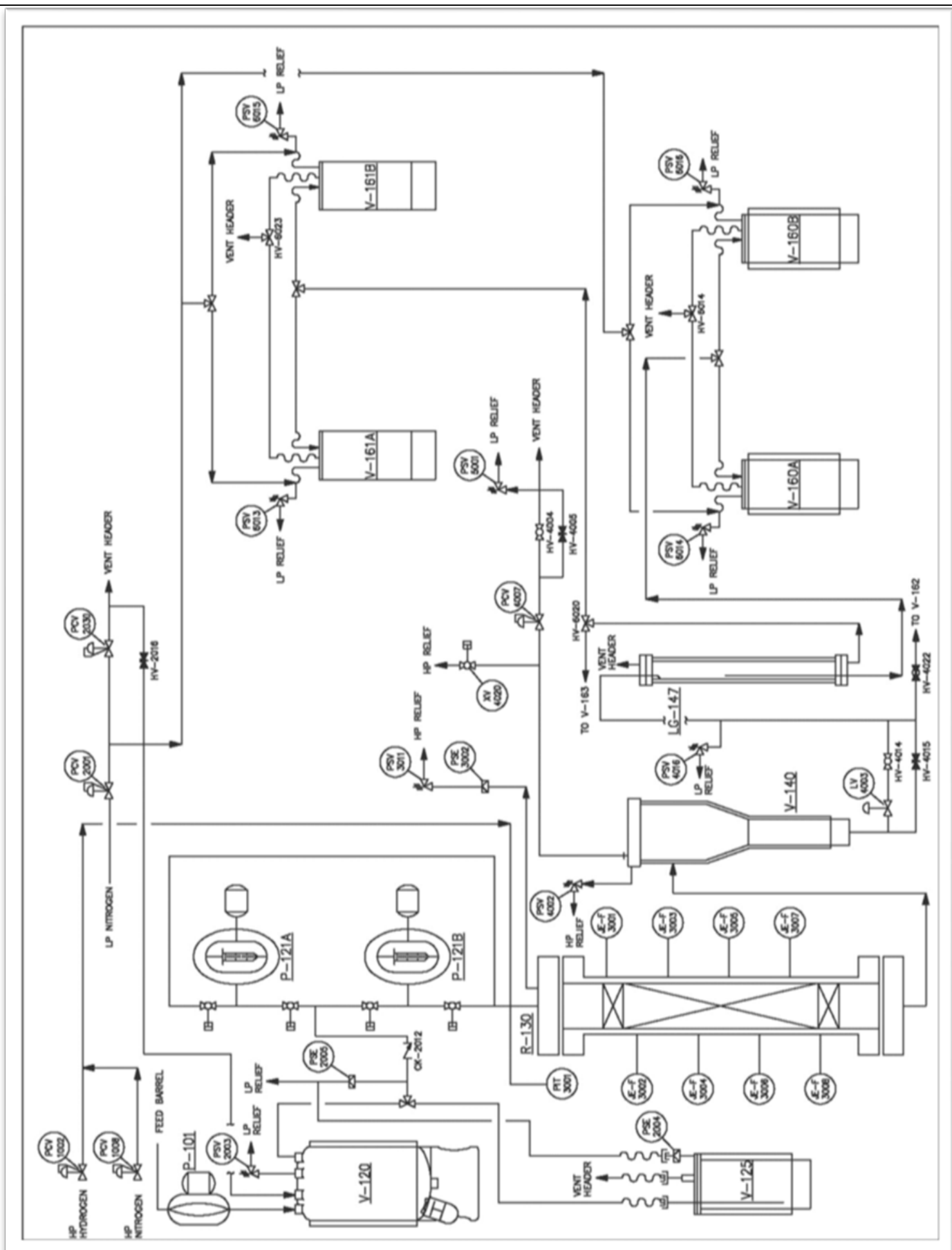

Figure 2-4. Hydrotreater Process Major Components 
Hydrotreater/Distillation Column Hazard Analysis Report

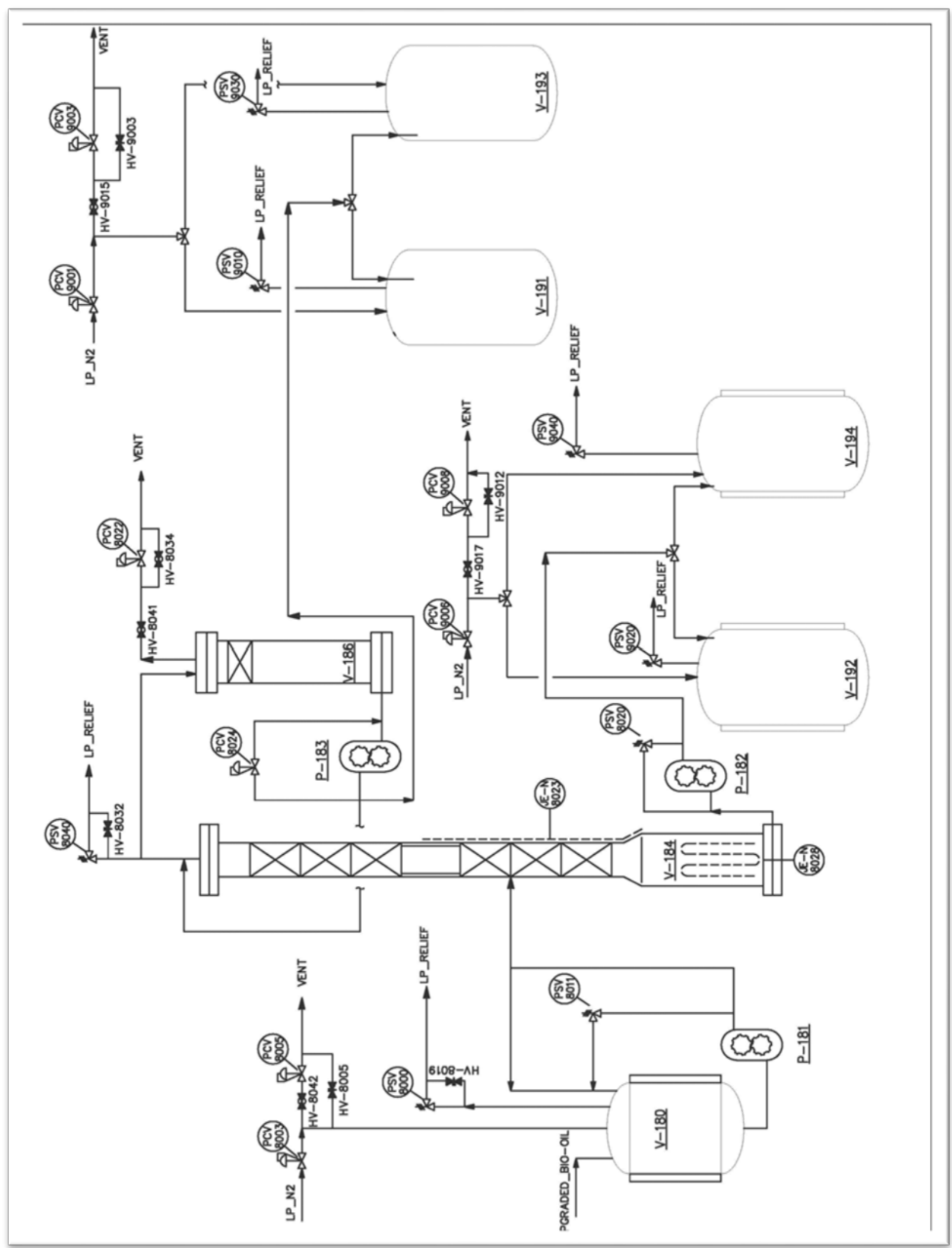

Figure 2-5. Distillation Process Major Components 


\subsubsection{Hydrotreater Operations Outline}

Prestart Operations

1) Install reactor

2) Chain out inter-skid area prior to working on upper head.

3) Load catalyst

4) Seal reactor

5) Pre-op valve position check for entire system

6) Connect bio-oil tank

7) Pressure check system

8) Put valves to flow positions

9) Transfer bio-oil to feed tank

Startup/Sulfiding

1) Clear area of all maintenance work and equipment not compatible with Class 1 Div 2 environment

2) Initiate purge of electrical cabinets and furnace.

3) Put sulfiding tank in place

4) Direct product valves to slop tank

5) Fill pumps with sulfiding solution

6) Pressurize reactor to operating pressure

7) Flow hydrogen at sulfiding flowrate and verify offgas handling system flow

8) Bring reactor to sulfiding temperature

9) Begin sulfiding flow

10) Ramp temperature through sulfiding procedure

11) Block out and remove sulfiding tank

Bio-oil feeding

1) Adjust hydrogen flow and temperature to operating conditions

2) Fill pumps with bio-oil from feed tank

3) Start bio-oil supply drum recirculation/take-up loop

4) Direct product valves to $\mathrm{L} / \mathrm{L}$ separator and A or B product tanks

5) Start bio-oil feed at $~ 30 \%$ of target flowrate

6) Allow system to equilibrate

7) Gradually bring reactor to target flowrate

Operation

1) Monitor feed and product levels

2) When product drums are at 85 to $90 \%$ full, switch to other product tanks

3) Download water vessel to product container

4) Download oil vessel to product container or transfer to still skid feed tank 
Transfer to still feed tank

1) Pad oil product container

2) Depad still feed tank

3) Connect transfer line

4) Open transfer valves

5) When empty, close transfer valves

6) Pad still tank

7) Depad product container

8) Remove transfer line

Shutdown

1) Stop oil feed and turn off reactor heaters.

2) Continue product vessel monitoring per "operation" section

3) Empty pumps back to bio-oil feed tank

4) Reduce gas flow once product collection has diminished

5) Allow reactor to cool

Flush

1) Reactor should be around $150 \mathrm{C}$ or lower for this procedure

2) Load acetone into pumps via transfer tank

3) Direct product valves to slop tank

4) Inject acetone into reactor

5) Shut down feed system and allow reactor to cool below 100C

6) Halt gas flow and depressurize reactor

7) Flush with $\mathrm{N}_{2}$

8) Verify that all systems are off

Refit

1) Depressurize and verify zero energy state on all hydrotreater subsystems

2) Chain out inter-skid area prior to working on upper head

3) Open upper reactor head.

4) Remove catalyst

\subsubsection{Distillation Operations Outline}

Prestart Operations

1) Seal process tanks

2) Pre-op valve position check for entire system

3) Pressure check system (purge and pad all subsystems)

4) Transfer feed to tank via hydrotreater skid or transfer tank using tank pads

5) Alternately, feed can be loaded into one of the bottoms product tanks and padded over

6) Put valves to flow positions, including bottoms and distillate product tanks

7) Prime feed pump and turn to auto control 
Startup

1) Clear area of all maintenance work and equipment not compatible with Class 1 Div 2 environment

2) Initiate purge of electrical cabinets and furnace

3) Turn on coolant to HX and to bottoms pump

4) Turn on nitrogen purge to heatup setpoint and set system backpressure

5) Engage feed pump and set backpressure loop

6) Fill still bottom to submerge heater elements via feed control badger and/or bypass.

7) Turn on still heater and external jacket heater

8) As liquid level drops in still, set feed badger to maintain liquid height in still

Reflux

1) Observe reflux in sight glass via level sensor

2) Once distillate reaches 8 inches, engage reflux pump (P-183) and set backpressure loop

3) Prime reflux pump

4) Set reflux badger to target $\mathrm{kg} / \mathrm{hr}$

5) Set product badger to target liquid level in sight glass

6) Reduce nitrogen flow to target setpoint and adjust system backpressure

Full operation

1) Set feed rate badger to target feed rate

2) Turn on and prime bottoms level control pump to target setpoint

3) Monitor liquid level on bottoms and distillate tanks, and switch to alternate tank when full

4) Monitor feed tank level

Shutdown

1) Turn off still heater and jacket.

2) Halt feed pump and set feed badger to zero

3) Close reflux badger.

4) Set reflux level control to zero to drain reflux glass into distillate product

5) Turn off reflux pump after low level indicator

6) Set bottoms level control to zero

7) Turn off bottoms level pump after low level indictor

8) Turn on nitrogen sweep to low level 


\subsection{HAZARD ASSESSMENT}

A series of facilitated hazards analysis sessions were conducted in February 2013. These hazard analysis sessions built upon the previous hazards analysis documented in the November 2012 Hydrotreater / Distillation Column Project Hazard and Risk Analysis Report. The scope of the February assessment was focused on the operations and hazards associated with the processrelated system components forming the hydrotreater/distillation column processes located within the PDL-West facility and the potential interactions of these hazards with respect to supporting systems and the facility. The PNNL team assembled for the hazards analysis sessions included Engineering (F\&O and Project); R\&D operations and engineering; Fire Protection; Pressure Systems; Environmental, Safety and Health; and hazard and safety analysts. PNSO observers also attended. Appendix A lists the attendees at the hazards analysis sessions. (Note: not all attendees listed were present for the entire duration; however, a core team representing design, operations, fire protection, pressure systems, and hazard and safety analysis was always present.)

The following sections provide a brief description of hazard evaluations performed and results of the evaluations.

\subsection{Hazard Identification}

The first step of the hazard analysis process was to identify the form, quantities, and characteristics of hazards, including chemicals associated with the major process components (Hazard Identification). This allowed the screening of hazards considered as normal laboratory practices or activities incidental to the operation of the facility to be addressed through IOPS and existing PNNL work controls. For the hydrotreater/distillation column processes, significant hazards requiring further evaluation via the hazards analysis process included high pressure processes and the presence of flammable and combustible liquids and gases. Table 3-1 identifies the product of the hazard identification process.

Regulatory provisions of 40 CFR 355, 29 CFR 1910.119, and 40 CFR 68 provide guidance relative to screening chemical hazards based on quantities and the potential consequences they represent to workers and the public. As shown in Table 3-2, these threshold values are many times greater in magnitude than those of the process chemicals and products common to the hydrotreater/distillation column processes. 
Table 3-1. Hydrotreater Hazard Identification Checklist

\begin{tabular}{|c|c|c|c|}
\hline Component & Inventory & $\begin{array}{l}\text { Vessel } \\
\text { Volume } \\
\text { Liter }^{(1)}\end{array}$ & $\begin{array}{l}\text { Operating } \\
\text { Pressure } \\
\text { psig }\end{array}$ \\
\hline Supply Drum & Bio-Oil & 55 gal & Atm \\
\hline $\mathrm{V}-120$ & Bio-Oil (filtered) & 72 & 10 \\
\hline $\mathrm{V}-125$ & $\begin{array}{l}\text { Di-tert-butyl disulfide / } \\
\text { Acetone }\end{array}$ & 20 & 10 \\
\hline $\mathrm{R}-130$ & $\begin{array}{l}\text { Treated Bio-Oil } \\
\text { Hydrogen }\end{array}$ & 26 & 2100 \\
\hline V-140/LG-142 & $\begin{array}{l}\text { Treated Bio-Oil } \\
\text { Hydrogen }\end{array}$ & 6 & 2100 \\
\hline LG-147 & Treated Bio-Oil & $4^{(2)}$ & Atm \\
\hline $\mathrm{V}-160 \mathrm{~A} / \mathrm{B}$ & Treated Bio-Oil & 20 & 10 \\
\hline $\mathrm{V}-161 \mathrm{~A} / \mathrm{B}$ & Process Water & 20 & 10 \\
\hline V-162 & Slop Bio-oil & $38^{(3)}$ & 10 \\
\hline V-163 & Process Water & $38^{(3)}$ & 10 \\
\hline V-180 & $\begin{array}{l}\text { Treated Bio-Oil } \\
\text { Light Product (recycle) } \\
\text { Bottoms Product (recycle) }\end{array}$ & $140^{(4)}$ & 10 \\
\hline V-184 & $\begin{array}{l}\text { Treated Bio-Oil } \\
\text { Light Product (recycle) } \\
\text { Bottoms Product (recycle) }\end{array}$ & $16^{(4)}$ & 15 \\
\hline $\begin{array}{l}\mathrm{V}-191 \\
(\mathrm{~V}-193)\end{array}$ & $\begin{array}{l}\text { Light Distillates (e.g. } \\
\text { naphtha, gasoline, jet) }\end{array}$ & 72 & 10 \\
\hline $\begin{array}{l}\mathrm{V}-192 \\
(\mathrm{~V}-194)\end{array}$ & $\begin{array}{l}\text { Bottoms Product (e.g., } \\
\text { diesel, cycle oil) }\end{array}$ & 72 & 10 \\
\hline 1/4"-T035-316 & $\begin{array}{l}\text { High Pressure (3000 psi) } \\
\text { Hydrogen }\end{array}$ & - & 2500 \\
\hline $\begin{array}{l}\text { 1/4"-T035-316 } \\
\text { 1/2"-T035-316 }\end{array}$ & $\begin{array}{l}\text { Low Pressure (100 psi) } \\
\text { Nitrogen }\end{array}$ & - & 100 \\
\hline 1/4"-T035-316 & $\begin{array}{l}\text { High Pressure (3000 psi) } \\
\text { Nitrogen }\end{array}$ & - & 2500 \\
\hline
\end{tabular}

(1) From CTI 12-631, unless otherwise noted.

(2) Project Drawing-782-4-140

(3) Project Drawing-782-4-160

(4) Project Drawing-782-4-180 
Table 3-2. Comparison of Chemicals to Screening Thresholds

\begin{tabular}{|c|c|c|c|}
\hline Material & 40 CFR 355 & 29 CFR 1910.119 & 40 CFR 68 \\
\hline Bio-Oil & Not Listed & Not Listed & Not Listed \\
\hline Treated Bio-Oil ${ }^{(a)}$ & Not Listed & Not Listed & Not Listed \\
\hline $\begin{array}{l}\text { Light Distillate } \\
\text {-naphtha } \\
\text {-gasoline } \\
\text {-jet fuel }\end{array}$ & Not Listed & $\begin{array}{c}\text { 10,000 lbs } \\
\text { (flammable } \\
\text { liquids) }\end{array}$ & Not Listed \\
\hline $\begin{array}{l}\text { Bottoms Product } \\
\text {-diesel } \\
\text {-cycle oil }\end{array}$ & Not Listed & $\begin{array}{c}\text { Not Listed } \\
\text { (combustible } \\
\text { liquids) }\end{array}$ & Not Listed \\
\hline $\begin{array}{l}\text { Nitrogen } \\
\text { (Compressed Gas) }\end{array}$ & Not Listed & Not Listed & Not Listed \\
\hline Hydrogen (Gas) & Not Listed & $\begin{array}{c}10,000 \text { lbs } \\
\text { (flammable gas) }\end{array}$ & $\begin{array}{c}\text { 10,000 lbs } \\
\text { (flammable } \\
\text { gas) }\end{array}$ \\
\hline Acetone & Not Listed & Not Listed & Not Listed \\
\hline $\begin{array}{l}\text { Di-tert-butyl } \\
\text { disulfide }\end{array}$ & Not Listed & Not Listed & Not Listed \\
\hline $\begin{array}{l}\text { Hydrogen } \\
\text { Sulfide }^{(b)}\end{array}$ & $100 / 500 \mathrm{lbs}^{(\mathrm{c})}$ & 1500 lbs & 10,000 lbs \\
\hline
\end{tabular}

(a) Assumed to be bio-diesel, http://www.apexoil.com/msdsbio.pdf

(b) Byproduct of hydrotreatment and sulfiding process

(c) Reportable quantity/planning threshold quantity 


\subsection{What-If Analysis}

The What-If analysis technique is a structured brainstorming method of determining potential undesired events (what things can go wrong). The answers to these what-if questions form the basis for making judgments regarding the acceptability of the controls that prevent or mitigate hazardous conditions and determining a recommended course of action for events requiring further consideration. The What-If concept encourages the team to think of potential upsets or deviations based on initiating questions generally beginning with "What if...".

As noted in Section 3.0, facilitated hazards analysis sessions were held in February 2013 following incorporation of design changes resulting from review comments and actions from the hazards analysis documented in the November 2012 Hydrotreater / Distillation Column Project Hazard and Risk Analysis Report. The What-If sessions were held in two blocks of time; a fourday session covering the hydrotreater process and supporting systems followed by a two-day session to cover the distillation column process and interface with PDL-West facility systems. Involvement by the participants was outstanding, particularly the operations team which had recently returned from the Factory Acceptance Testing held at the vendor's facilities.

The What-If analysis was structured around the process steps of hydrotreater and distillation operations as outlined in Sections 2.1.1 and 2.1.2. The scope of the hazards analysis focused on the process systems and potential for adverse interactions to the process from upsets in the supporting utilities. For the hydrotreater and distillation column processes, a selected operator presented the key process steps in his/her area of expertise followed by a series of What-If questions posed for each step. The What-If team leveraged the operators' recent test experience to gain insight on the operation of the systems under postulated off-normal or upset conditions. The process and utility drawings reviewed included redline drawings from the factory acceptance test, as appropriate, to reflect the most current state of the design and are identified in Appendix B, “Key Design Information Reviewed.”

As part of the What-If analysis, a qualitative likelihood was assigned to all unmitigated hazardous scenarios. This reflected the team's estimation regarding the likelihood of an initiating event coupled with a postulated upset condition, absent of the preventive or mitigative effects of hazard controls (i.e., unmitigated). The basis for the likelihood of a given hazardous scenario was the number and types of operational failures needed to result in the identified potential upset condition (Table 3-3).

Each hazardous scenario was further defined by qualitative evaluations of the potential unmitigated consequences such as: process upset; exposure of personnel to steam, vapors or asphyxiant; spray or spill of flammable material; creation of a flammable atmosphere; or energetic release events from a vessel pressure boundary (boiling liquid expanding vapor explosion [BLEVE] or pressure vessel burst [PVB]). It was clarified that the unmitigated consequences identified during the analysis were not sure to occur even under the failures postulated; rather the consequences identified represent the bounding case outcomes in most instances, rather than a less significant expected outcome.

\footnotetext{
${ }^{1}$ These design documents are historical and subject to change. See the Hydrotreater/Distillation Column SharePoint site for current design documents.
} 
Table 3-3. Likelihoods Used for the Hydrotreater/Distillation Column What-If Analysis

\begin{tabular}{|l|l|}
\hline Likelihood & Qualitative Evaluation Criteria \\
\hline Likely & $\begin{array}{l}\text { Failure of a single process control, failure of active } \\
\text { components or support systems (e.g., power), or } \\
\text { administrative steps }\end{array}$ \\
\hline Unlikely & $\begin{array}{l}\text { Conditions involving failure of two or more of the above, } \\
\text { mechanical failures of active systems (e.g., pump/motor } \\
\text { failures) }\end{array}$ \\
\hline $\begin{array}{l}\text { Very } \\
\text { Unlikely }\end{array}$ & $\begin{array}{l}\text { Multiple failures (more than 2), failures of robust passive } \\
\text { systems }\end{array}$ \\
\hline $\begin{array}{l}\text { Extremely } \\
\text { Unlikely }\end{array}$ & Many concurrent, independent failures \\
\hline
\end{tabular}

\subsection{Analysis Results}

The results of the What-If analysis are provided in Table 3-4. For all releases of hazardous material or energy, controls were identified to prevent the occurrence or mitigate the effects of the release (Table 3-4). Footnotes have been added to Table 3-4 to provide addendum information pertinent to the analysis.

Approximately 66 highly energetic releases (33) BLEVE and PVB and (33) potential deflagrations were identified. For these events, additional analysis was performed (Section 3.3) to determine the potential magnitude of the impacts from the event to receptor locations within and outside of the PDL-West building for bounding scenarios of each type. The critical controls credited to mitigate the likelihood or consequences of these events are identified in the hazard analysis tables and summarized in Chapter 4.0.

One action affecting control selection was identified during the What-If analysis for scenarios H.2-17 and H.6-1. This action replaces the "T" upstream of HV-2009/2006 with HV-2018, a 3 way valve (e.g., Swagelock@ SS-H83PS8) to provide positive isolation from potential reactor backpressure during pump flushing operations.

No other control-affecting actions were identified or required to assure adequate protection against the release of hazardous material or energy during the What-If analysis sessions. In some cases, the What-If team identified suggestions to improve the design and operational processes. These suggestions were captured for consideration by project management. 


\section{Hydrotreater/Distillation Column Hazard Analysis Report}

Table 3-4. What-If Hazards Analysis Results

\begin{tabular}{|c|c|c|c|c|c|c|c|}
\hline \multicolumn{8}{|c|}{$\begin{array}{l}\text { Hydrotreater Process Step 1. Prestart Operations } \\
\text { 1) Install reactor. 2) Chain out inter-skid area prior to working on upper head. 3) Load catalyst. 4) Seal reactor. 5) Pre-op valve position check for entire system. 6) Connect bio-oil tank. } \\
\text { 7) Pressure check system. 8) Put valves to flow positions. 9) Transfer bio-oil to feed tank. }\end{array}$} \\
\hline $\begin{array}{l}\text { Hazar } \\
\text { ID/ } \\
\text { Proce } \\
\text { Step }\end{array}$ & & What if: & Hazardous Scenario & $\begin{array}{l}\text { Likeli- } \\
\text { hood }\end{array}$ & Consequences & $\begin{array}{l}\text { Hazard Controls } \\
\mathrm{C}=\text { Critical Control }\end{array}$ & Comments \\
\hline $\begin{array}{l}\text { H.1- } \\
1\end{array}$ & 1 & $\begin{array}{l}\text { What if we drop or impact } \\
\text { the reactor? }\end{array}$ & $\begin{array}{l}\text { Damage reactor } \\
\text { thermocouple from } \\
\text { dropping reactor or running } \\
\text { it into object results in loss } \\
\text { of thermocouple } \\
\text { functionality }\end{array}$ & Likely & $\begin{array}{l}\text { Process upset. During } \\
\text { sulfiding or operating steps. } \\
\text { (also see heater/thermocouple } \\
\text { events in subsequent process } \\
\text { steps) }\end{array}$ & $\begin{array}{l}\text { Lift Procedure and engineered lift } \\
\text { points on vessel. } \\
\text { Pressure Test Procedure on } \\
\text { startup. } \\
\text { Instrument test Procedure } \\
\text { Interlocks on thermocouple. }\end{array}$ & \\
\hline $\begin{array}{l}\text { H.1- } \\
2\end{array}$ & 1 & $\begin{array}{l}\text { What if we impact another } \\
\text { piece of equipment or } \\
\text { piping? }\end{array}$ & $\begin{array}{l}\text { Damage to furnace or } \\
\text { furnace door due to impact } \\
\text { (for instance reactor vessel) } \\
\text { results in short circuit of } \\
\text { heater or damage to furnace } \\
\text { door and it might not shut } \\
\text { properly. }\end{array}$ & Likely & $\begin{array}{l}\text { Short circuit of heater leads to } \\
\text { high temperature in reactor } \\
\text { during sulfiding operations } \\
\text { and potential energetic event } \\
\text { due to pressure boundary } \\
\text { failure. (see subsequent events } \\
\text { e.g., H.2-3, H.2-20) } \\
\text { Loss of purge operations, } \\
\text { during sulfiding or operating } \\
\text { steps, leads to potential } \\
\text { ignitions of flammable gases } \\
\text { in reactor furnace- requires } \\
\text { concurrent failure in pressure } \\
\text { boundary. (see subsequent } \\
\text { events e.g., H.2-3) }\end{array}$ & $\begin{array}{l}\text { Lift Procedure and engineered lift } \\
\text { points on vessel. } \\
\text { Heater circuits are fused } \\
\text { (protection against short circuit) } \\
\text { Pressure indication (alarm) on } \\
\text { furnace Z purge. }\end{array}$ & \\
\hline $\begin{array}{l}\text { H.1- } \\
3\end{array}$ & 3 & $\begin{array}{l}\text { What if you improperly } \\
\text { load the column? }\end{array}$ & $\begin{array}{l}\text { Failure to properly prepare } \\
\text { the column before adding } \\
\text { catalyst. (Forgetting the } \\
\text { screen would result in the } \\
\text { catalyst running down exit } \\
\text { hole and plugging up the } 90 \\
\text { degree bend.) }\end{array}$ & Likely & $\begin{array}{l}\text { Process upset during sulfiding } \\
\text { or operating steps. } \\
\text { Plugging the reactor flow path } \\
\text { and/or plug filter (F-4019) } \\
\text { downstream of separator with } \\
\text { pressurization of the reactor. }\end{array}$ & $\begin{array}{l}\text { Pressure Test Procedure. } \\
\text { High Pressure Nitrogen Supply } \\
\text { set @ } 3000 \text { psi. } \\
\text { High Pressure Nitrogen System } \\
\text { set @ } 2500 \text { psi. }\end{array}$ & \\
\hline
\end{tabular}




\section{Hydrotreater/Distillation Column Hazard Analysis Report}

Table 3-4. What-If Hazards Analysis Results

\begin{tabular}{|c|c|c|c|c|c|c|c|}
\hline \multicolumn{8}{|c|}{$\begin{array}{l}\text { Hydrotreater Process Step 1. Prestart Operations } \\
\text { 1) Install reactor. 2) Chain out inter-skid area prior to working on upper head. 3) Load catalyst. 4) Seal reactor. 5) Pre-op valve position check for entire system. 6) Connect bio-oil tank. } \\
\text { 7) Pressure check system. 8) Put valves to flow positions. 9) Transfer bio-oil to feed tank. }\end{array}$} \\
\hline $\begin{array}{l}\text { Hazar } \\
\text { ID/ } \\
\text { Proces } \\
\text { Step }\end{array}$ & & What if: & Hazardous Scenario & $\begin{array}{l}\text { Likeli- } \\
\text { hood }\end{array}$ & Consequences & $\begin{array}{l}\text { Hazard Controls } \\
\text { C = Critical Control }\end{array}$ & Comments \\
\hline $\begin{array}{l}\text { H.1- } \\
4\end{array}$ & 3 & $\begin{array}{l}\text { What if you use the wrong } \\
\text { catalyst? }\end{array}$ & $\begin{array}{l}\text { Failure to select the right } \\
\text { catalyst (matched to } \\
\text { sulfiding agent and bio-oil, } \\
\text { operating conditions). }\end{array}$ & Likely & $\begin{array}{l}\text { Process upset during sulfiding } \\
\text { or operating steps. } \\
\text { Potential plugging of the } \\
\text { reactor flowpath (due to heavy } \\
\text { oils) with pressurization of the } \\
\text { reactor. If left for long period } \\
\text { potential complete blockage } \\
\text { See H.4-6 }\end{array}$ & $\begin{array}{l}\text { Startup operating procedure - } \\
\text { gradual start up. } \\
\text { Pre-testing/qualification } \\
\text { (benchtop) of new catalyst- } \\
\text { sulfiding combinations for use } \\
\text { with bio-oils. }\end{array}$ & $\begin{array}{l}\text { Pyrophoric catalysts are not } \\
\text { currently proposed. }\end{array}$ \\
\hline $\begin{array}{l}\text { H.1- } \\
5\end{array}$ & 3 & $\begin{array}{l}\text { What if you introduce } \\
\text { wrong material? }\end{array}$ & $\begin{array}{l}\text { Introduction of wrong } \\
\text { catalyst results in failure to } \\
\text { produce quality product. }\end{array}$ & Unlikely & $\begin{array}{l}\text { Process upset during sulfiding } \\
\text { or operating steps. } \\
\text { Potential plugging of the } \\
\text { reactor flowpath (due to heavy } \\
\text { oils) with pressurization of the } \\
\text { reactor. If left for long period } \\
\text { potential complete blockage } \\
\text { See H.4-6 }\end{array}$ & $\begin{array}{l}\text { Startup operating procedure - } \\
\text { gradual start up. } \\
\text { Pressure monitoring. }\end{array}$ & \\
\hline $\begin{array}{l}\text { H.1- } \\
6\end{array}$ & 3 & $\begin{array}{l}\text { What if you don't put } \\
\text { enough catalyst into } \\
\text { reactor? }\end{array}$ & $\begin{array}{l}\text { Failure to add sufficient } \\
\text { catalyst results in failure to } \\
\text { produce quality product. }\end{array}$ & Likely & $\begin{array}{l}\text { Process upset during sulfiding } \\
\text { or operating steps. } \\
\text { Potential plugging of the } \\
\text { reactor flowpath (due to heavy } \\
\text { oils) with pressurization of the } \\
\text { reactor. If left for long period } \\
\text { potential complete blockage } \\
\text { See H.4-6 }\end{array}$ & $\begin{array}{l}\text { Startup operating procedure - } \\
\text { gradual start up. } \\
\text { Procedural- Keep track of volume } \\
\text { of catalyst added. } \\
\text { Pressure monitoring. }\end{array}$ & $\begin{array}{l}\text { Cannot overfill with catalyst } \\
\text { and still close reactor head. }\end{array}$ \\
\hline $\begin{array}{l}\text { H.1- } \\
7\end{array}$ & 4 & $\begin{array}{l}\text { What if there is failure to } \\
\text { properly reassemble } \\
\text { reactor } \\
\text { seals/flanges/piping } \\
\text { connections? }\end{array}$ & $\begin{array}{l}\text { Failure to properly re- } \\
\text { assemble reactor } \\
\text { components (e.g., forget to } \\
\text { install VCR nickel gaskets). }\end{array}$ & Likely & $\begin{array}{l}\text { Exposure of personnel. } \\
\text { Release of nitrogen into } \\
\text { enclosure during pressure } \\
\text { testing. }\end{array}$ & $\begin{array}{l}\text { Assembly Procedures. } \\
\text { Pressure Test Procedure. } \\
\text { Low pressure alarms. }\end{array}$ & \\
\hline
\end{tabular}




\section{Hydrotreater/Distillation Column Hazard Analysis Report}

Table 3-4. What-If Hazards Analysis Results






\section{Hydrotreater/Distillation Column Hazard Analysis Report}

Table 3-4. What-If Hazards Analysis Results

\begin{tabular}{|c|c|c|c|c|c|c|c|c|}
\hline \multicolumn{9}{|c|}{$\begin{array}{l}\text { Hydrotreater Process Step 1. Prestart Operations } \\
\text { 1) Install reactor. 2) Chain out inter-skid area prior to working on upper head. 3) Load catalyst. 4) Seal reactor. 5) Pre-op valve position check for entire system. 6) Connect bio-oil tank. } \\
\text { 7) Pressure check system. 8) Put valves to flow positions. 9) Transfer bio-oil to feed tank. }\end{array}$} \\
\hline $\begin{array}{l}\text { Hazarc } \\
\text { ID/ } \\
\text { Proces } \\
\text { Step }\end{array}$ & & What if: & Hazardous Scenario & $\begin{array}{l}\text { Likeli- } \\
\text { hood }\end{array}$ & Consequences & $\begin{array}{l}\text { Hazard Controls } \\
\text { C = Critical Control }\end{array}$ & & Comments \\
\hline $\begin{array}{l}\text { H.1- } \\
13\end{array}$ & 6 & $\begin{array}{l}\text { What if failed to connect } \\
\text { return line to drum? }\end{array}$ & $\begin{array}{l}\text { Failure to connect return } \\
\text { line to feed drum results in } \\
\text { release of Bio-oil. }\end{array}$ & Likely & $\begin{array}{l}\text { Spray/Spill. } \\
\text { Spill of Bio-Oil into } \\
\text { enclosure. Cleanup. }\end{array}$ & $\begin{array}{l}\text { Procedural check. } \\
\text { Secondary containment on the } \\
\text { drum. }\end{array}$ & & \\
\hline $\begin{array}{l}\text { H.1- } \\
14\end{array}$ & 7 & $\begin{array}{l}\text { What if fail to do the } \\
\text { pressure test? }\end{array}$ & $\begin{array}{l}\text { Failure to perform pressure } \\
\text { check, combined with pre- } \\
\text { existing leak or failure to re- } \\
\text { assemble properly results in } \\
\text { leak at operating } \\
\text { temperature and pressure. }\end{array}$ & Likely & $\begin{array}{l}\text { Flammable atmosphere, } \\
\text { during subsequent operations. } \\
\text { Leak of hydrogen/bio-oil or } \\
\text { sulfiding agent /steam into } \\
\text { enclosure. } \\
\text { High pressure spray of (jet } \\
\text { flame) of combustible liquid } \\
\text { and potential creation of } \\
\text { flammable atmosphere } \\
\text { mitigated by steam. }\end{array}$ & $\begin{array}{l}\text { Hydrogen monitors on skid and } \\
\text { in enclosure. } \\
\text { Enclosure Design - Class } 1 \\
\text { Division } 2 . \\
\text { Enclosure Ventilation System. } \\
\text { Flammable vapor monitor on } \\
\text { skid. } \\
\text { Low pressure alarm - R-130. }\end{array}$ & $\begin{array}{l}\mathrm{C} \\
\mathrm{C} \\
\mathrm{C} \\
\mathrm{C}\end{array}$ & \\
\hline $\begin{array}{l}\text { H.1- } \\
15\end{array}$ & 7 & $\begin{array}{l}\text { What if too high pressure } \\
\text { for low pressure system? }\end{array}$ & $\begin{array}{l}\text { Over pressurization of low } \\
\text { pressure system } \\
\text { components due to } \\
\text { excessive nitrogen pressure }\end{array}$ & Unlikely & $\begin{array}{l}\text { Energetic event - over- } \\
\text { pressurization of low pressure } \\
\text { system (>100 psi) }\end{array}$ & $\begin{array}{l}\text { Pressure regulation of the low } \\
\text { pressure nitrogen supply to } 100 \\
\text { psi. } \\
\text { Pressure regulation of the low } \\
\text { pressure nitrogen system pressure } \\
\text { to } 10 \text { psi. } \\
\text { Low pressure component PRVs } \\
\text { set at } \leq 100 \text { psi. } \\
\text { Pressure Test Procedure. }\end{array}$ & $\mathrm{C}$ & \\
\hline $\begin{array}{l}\text { H.1- } \\
16\end{array}$ & 7 & $\begin{array}{l}\text { What if too high pressure } \\
\text { for high pressure system? }\end{array}$ & $\begin{array}{l}\text { Over pressurization of high } \\
\text { pressure system } \\
\text { components due to } \\
\text { excessive nitrogen pressure. }\end{array}$ & Unlikely & $\begin{array}{l}\text { Energetic event - over- } \\
\text { pressurization of high pressure } \\
\text { system (>3000 psi) }\end{array}$ & $\begin{array}{l}\text { Pressure regulation of the high } \\
\text { pressure nitrogen supply to } 3000 \\
\text { psi. } \\
\text { Pressure regulation of high } \\
\text { pressure nitrogen system pressure } \\
\text { set at } 2500 \text { psi. } \\
\text { High pressure component PRVs } \\
\text { set at } 3000 \text { psi. } \\
\text { High pressure vessel and } \\
\text { component design pressure } \geq \\
3000 \text { psi. } \\
\text { High pressure alarms. } \\
\text { High pressure interlocks. }\end{array}$ & $\mathrm{C}$ & \\
\hline
\end{tabular}




\section{Hydrotreater/Distillation Column Hazard Analysis Report}

Table 3-4. What-If Hazards Analysis Results

\begin{tabular}{|c|c|c|c|c|c|c|c|c|}
\hline \multicolumn{9}{|c|}{$\begin{array}{l}\text { Hydrotreater Process Step 1. Prestart Operations } \\
\text { 1) Install reactor. 2) Chain out inter-skid area prior to working on upper head. 3) Load catalyst. 4) Seal reactor. 5) Pre-op valve position check for entire system. 6) Connect bio-oil tank. } \\
\text { 7) Pressure check system. 8) Put valves to flow positions. 9) Transfer bio-oil to feed tank. }\end{array}$} \\
\hline $\begin{array}{l}\text { Hazar } \\
\text { ID/ } \\
\text { Proces } \\
\text { Step }\end{array}$ & & What if: & Hazardous Scenario & $\begin{array}{l}\text { Likeli- } \\
\text { hood }\end{array}$ & Consequences & $\begin{array}{l}\text { Hazard Controls } \\
\mathrm{C}=\text { Critical Control }\end{array}$ & & Comments \\
\hline $\begin{array}{l}\text { H.1- } \\
17\end{array}$ & 7 & $\begin{array}{l}\text { What if you inadvertently } \\
\text { use Hydrogen instead of } \\
\text { nitrogen for leak check? }\end{array}$ & $\begin{array}{l}\text { Failure to use correct gas } \\
\text { for pressure check } \\
\text { (combined with pre-existing } \\
\text { leak or failure to re- } \\
\text { assemble properly) results } \\
\text { in potential flammable } \\
\text { atmosphere in the enclosure } \\
\text { with a piece of equipment } \\
\text { not qualified for the } \\
\text { hydrogen atmosphere. }\end{array}$ & Unlikely & $\begin{array}{l}\text { Flammable atmosphere. } \\
\text { Hydrogen buildup and } \\
\text { deflagration in Enclosure }\end{array}$ & $\begin{array}{l}\text { Pressure Test Procedure. } \\
\text { Valve and line labeling. } \\
\text { Hydrogen monitor on skid and in } \\
\text { enclosure. } \\
\text { Enclosure Ventilation System } \\
\text { operable prior to pressurizing the } \\
\text { system }\end{array}$ & $\begin{array}{l}\mathrm{C} \\
\mathrm{C} \\
\mathrm{C}\end{array}$ & \\
\hline $\begin{array}{l}\text { H.1- } \\
18\end{array}$ & 7 & $\begin{array}{l}\text { What if you inadvertently } \\
\text { use Hydrogen instead of } \\
\text { nitrogen for leak check? }\end{array}$ & $\begin{array}{l}\text { Failure to use correct gas } \\
\text { for pressure check results in } \\
\text { Hydrogen/Air atmosphere } \\
\text { in the reactor system, } \\
\text { potential ignition of } \\
\text { flammable atmosphere in } \\
\text { the system at a transition } \\
\text { point . }\end{array}$ & Likely & $\begin{array}{l}\text { Energetic event - Deflagration } \\
\text { in reactor column. }\end{array}$ & $\begin{array}{l}\text { Pressure Test Procedure. } \\
\text { Valves and Line labeling. }\end{array}$ & $\mathrm{C}$ & $\begin{array}{l}\text { Lack of ignition source } \\
\text { unless we are reusing the } \\
\text { catalyst. If we are reusing } \\
\text { column, it is kept at } \\
\text { pressure. There is no } \\
\text { oxygen. }\end{array}$ \\
\hline $\begin{array}{l}\text { H.1- } \\
19\end{array}$ & 8 & $\begin{array}{l}\text { What if there is failure to } \\
\text { line up properly for } \\
\text { operations? }\end{array}$ & $\begin{array}{l}\text { Failure to correctly align } \\
\text { system for operations after } \\
\text { pressure test results in } \\
\text { blocked flow within the } \\
\text { system up to liquid } \\
\text { separator. }\end{array}$ & Likely & $\begin{array}{l}\text { Energetic event during } \\
\text { subsequent operations. } \\
\text { Deadhead within system with } \\
\text { potential failure of pressure } \\
\text { boundary due to high pressure } \\
\text { in V-140 and reactor. }\end{array}$ & $\begin{array}{l}\text { Design of R-130/V-140 and } \\
\text { component pressure } \geq 3000 \text { psi } \\
\text { MAWP. } \\
\text { R-130/V-140 PRVs set at } 3000 \\
\text { psi. } \\
\text { Pressure regulation of the } \\
\text { hydrogen supply to } 3000 \text { psi. } \\
\text { Pressure regulation of hydrogen } \\
\text { system pressure set at } 2500 \text { psi. } \\
\text { High pressure alarm in R-130. } \\
\text { High-high pressure interlock in } \\
\text { R-130 }\end{array}$ & $\begin{array}{ll}\mathrm{C} \\
\mathrm{C}\end{array}$ & \\
\hline $\begin{array}{l}\text { H.1- } \\
20\end{array}$ & 8 & $\begin{array}{l}\text { What if an already closed } \\
\text { valve is inadvertently } \\
\text { opened? }\end{array}$ & $\begin{array}{l}\text { Inadvertent opening of } \\
\text { (drain/manual transfer) } \\
\text { valve results in venting to } \\
\text { enclosure or header }\end{array}$ & Unlikely & $\begin{array}{l}\text { Exposure to personnel. } \\
\text { Potential for nitrogen release } \\
\text { into enclosure or vent. }\end{array}$ & $\begin{array}{l}\text { Procedural Step. } \\
\text { Drains are double valved, valved } \\
\text { and capped, or valve and quick } \\
\text { disconnect. }\end{array}$ & & \\
\hline
\end{tabular}




\section{Hydrotreater/Distillation Column Hazard Analysis Report}

Table 3-4. What-If Hazards Analysis Results

\begin{tabular}{|c|c|c|c|c|c|c|c|c|}
\hline \multicolumn{9}{|c|}{$\begin{array}{l}\text { Hydrotreater Process Step 1. Prestart Operations } \\
\text { 1) Install reactor. 2) Chain out inter-skid area prior to working on upper head. 3) Load catalyst. 4) Seal reactor. 5) Pre-op valve position check for entire system. 6) Connect bio-oil tank. } \\
\text { 7) Pressure check system. 8) Put valves to flow positions. 9) Transfer bio-oil to feed tank. }\end{array}$} \\
\hline $\begin{array}{l}\text { Hazar } \\
\text { ID/ } \\
\text { Proces } \\
\text { Step }\end{array}$ & & What if: & Hazardous Scenario & $\begin{array}{l}\text { Likeli- } \\
\text { hood }\end{array}$ & Consequences & $\begin{array}{l}\text { Hazard Controls } \\
\mathrm{C}=\text { Critical Control }\end{array}$ & & Comments \\
\hline $\begin{array}{l}\text { H.1- } \\
21\end{array}$ & 8 & $\begin{array}{l}\text { What if failure to reopen a } \\
\text { valve on the low pressure } \\
\text { tanks? }\end{array}$ & $\begin{array}{l}\text { Failure to open vent } \\
\text { isolation valve in low } \\
\text { pressure system results in } \\
\text { blocked flow within the } \\
\text { system during sulfiding or } \\
\text { operations. }\end{array}$ & Likely & $\begin{array}{l}\text { Energetic event. Deadhead } \\
\text { within system, during } \\
\text { subsequent operations. High } \\
\text { pressure in vessels. }\end{array}$ & $\begin{array}{l}\text { Procedural Step. } \\
\text { PRVs on low pressure vessels. }\end{array}$ & $\mathrm{C}$ & \\
\hline $\begin{array}{l}\text { H.1- } \\
22\end{array}$ & 9 & $\begin{array}{l}\text { What if we transfer bio-oil } \\
\text { too fast or at too high of } \\
\text { pressure? }\end{array}$ & $\begin{array}{l}\text { Transfer of bio-oil to V-120 } \\
\text { at greater than expected } \\
\text { pressure or flow results in l } \\
\text { system breach }\end{array}$ & Likely & $\begin{array}{l}\text { Spray or spill. Release of bio- } \\
\text { oil into enclosure (also see } \\
\text { H.1.24). } \\
\text { Filter breakthrough. (See } \\
\text { H.1.27). }\end{array}$ & $\begin{array}{l}\text { Pump can only achieve maximum } \\
\text { supplied air pressure. } \\
\text { Air system pressure set at } \\
\text { nominally } 100 \text { psi (normal } \\
\text { operating pressure is } 80 \mathrm{psi} \text { ). } \\
\text { Filters are rated at } 250 \mathrm{psi} \text {. } \\
\text { V-120 rated at } 135 \mathrm{psi} \text {. PRV set } \\
\text { at } 70.3 / 4 \text { inch stainless steel } \\
\text { transfer line is rated at }>3000 \text { psi. }\end{array}$ & & $\begin{array}{l}\text { System designed for } \\
\text { maximum flow from pump } \\
\text { at maximum air supply } \\
\text { pressure. }\end{array}$ \\
\hline $\begin{array}{l}\text { H.1- } \\
23\end{array}$ & 9 & $\begin{array}{l}\text { What if there is transfer } \\
\text { too much bio-oil (over } \\
\text { fill)? }\end{array}$ & $\begin{array}{l}\text { Failure to stop transfer } \\
\text { results in over fill of V-120. }\end{array}$ & Likely & $\begin{array}{l}\text { Spray or spill. Overfill V-120 } \\
\text { resulting in release of bio-oil } \\
\text { into the vent system. }\end{array}$ & $\begin{array}{l}\text { V-120 level indicator. } \\
\text { V-120 high-high level interlocks. } \\
\text { - Interlock to pump (automatic } \\
\text { mode). } \\
\text { - Procedure, manual transfer } \\
\text { mode. }\end{array}$ & & \\
\hline $\begin{array}{l}\text { H.1- } \\
24\end{array}$ & 9 & $\begin{array}{l}\text { What if there is a leak in } \\
\text { the bio-oil line? }\end{array}$ & $\begin{array}{l}\text { Leak in transfer line results } \\
\text { in spill /spray to enclosure. }\end{array}$ & Likely & $\begin{array}{l}\text { Spray or spill. Release of bio- } \\
\text { oil into enclosure. }\end{array}$ & $\begin{array}{l}\text { Filtered oil (feed line) 3/4 SS } \\
\text { tubing. } \\
\text { Secondary containment provided } \\
\text { by enclosure. }\end{array}$ & & $\begin{array}{l}\text { This portion is not pressure } \\
\text { checked every time. }\end{array}$ \\
\hline $\begin{array}{l}\text { H.1- } \\
25\end{array}$ & 9 & What if the filters Plug? & $\begin{array}{l}\text { Potential plug leading to } \\
\text { high pressure in transfer } \\
\text { line from drum to V-120. }\end{array}$ & Likely & $\begin{array}{l}\text { Spray or spill. Release of bio- } \\
\text { oil into enclosure (also see } \\
\text { H.1.24). } \\
\\
\text { Filter breakthrough (See } \\
\text { H.1.27). }\end{array}$ & $\begin{array}{l}\text { Round sanitary clamp. Filter is } \\
\text { open at both ends. Use second } \\
\text { filter. The bypass allows you to } \\
\text { go to second filter. These will be } \\
\text { changed every week. }\end{array}$ & & \\
\hline $\begin{array}{l}\text { H.1- } \\
26\end{array}$ & 9 & $\begin{array}{l}\text { What if air gets in the } \\
\text { system? Is bio-oil foam a } \\
\text { hazard? }\end{array}$ & Air in reactor & Likely & $\begin{array}{l}\text { Process Upset. Unable to } \\
\text { pump. }\end{array}$ & $\begin{array}{l}\text { Low level control in V-120 and } \\
\text { interlocks associated with it. } \\
\text { ISCO pump shutoff due to } \\
\text { insufficient liquid refill. }\end{array}$ & & $\begin{array}{l}\text { Filters would most likely } \\
\text { break up foam. }\end{array}$ \\
\hline
\end{tabular}




\section{Hydrotreater/Distillation Column Hazard Analysis Report}

Table 3-4. What-If Hazards Analysis Results



\section{Hydrotreater Process Step 2. Startup/Sulfiding}

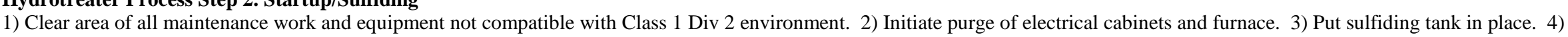
Direct product valves to slop tank. 5) Fill pumps with sulfiding solution. 6) Pressurize reactor to operating pressure. 7) Flow hydrogen at sulfiding flowrate and verify offgas handling system flow. 8) Bring reactor to sulfiding temperature. 9) Begin sulfiding flow. 10) Ramp temperature through sulfiding procedure. 11) Block out and remove sulfiding tank.

\begin{tabular}{|c|c|c|c|c|c|c|c|c|}
\hline $\begin{array}{l}\text { Hazar } \\
\text { Proces }\end{array}$ & & What if: & Hazardous Scenario & $\begin{array}{l}\text { Likeli- } \\
\text { hood }\end{array}$ & Consequences & $\begin{array}{l}\text { Hazard Controls } \\
\text { C = Critical Control }\end{array}$ & & Comments \\
\hline H.2-1 & 1 & $\begin{array}{l}\text { What if you leave non- } \\
\text { Class } 1 \text { Div } 2 \\
\text { equipment in } \\
\text { environment }\end{array}$ & $\begin{array}{l}\text { Presence of non-Class } 1 \\
\text { Division } 2 \text { equipment } \\
\text { presents a potential for a } \\
\text { subsequent ignition } \\
\text { source, given a like in the } \\
\text { process boundary }\end{array}$ & Likely & $\begin{array}{l}\text { Flammable atmosphere. } \\
\text { Potential ignition of a } \\
\text { flammable vapor given leak } \\
\text { sufficient to result in a } \\
\text { flammable atmosphere. }\end{array}$ & $\begin{array}{l}\text { Pressure Test Procedure. } \\
\text { Enclosure Ventilation System. } \\
\text { Hydrogen monitors on skid and } \\
\text { in enclosure. } \\
\text { Flammable vapor monitor on } \\
\text { skid. }\end{array}$ & C & \\
\hline
\end{tabular}




\section{Hydrotreater/Distillation Column Hazard Analysis Report}

Table 3-4. What-If Hazards Analysis Results

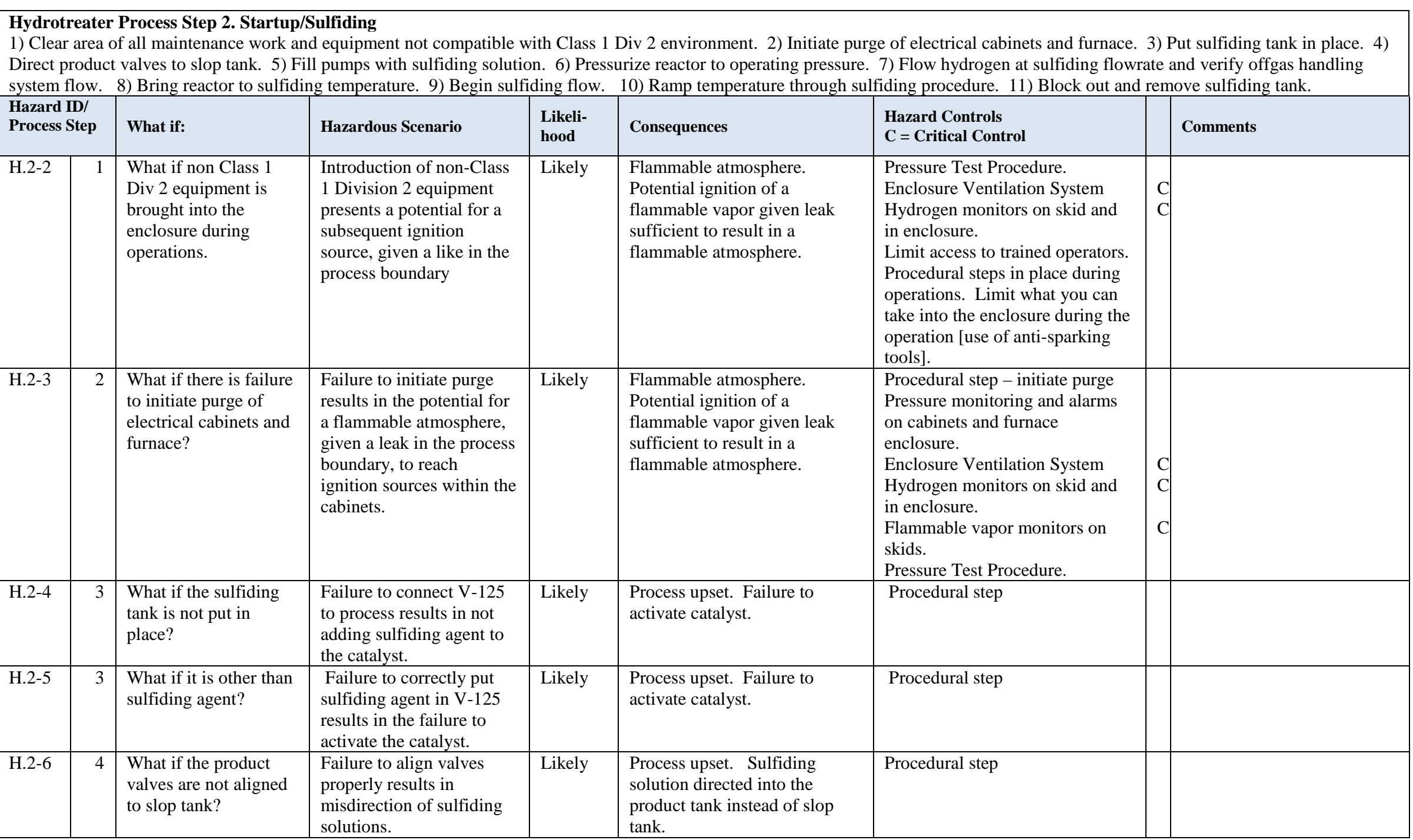




\section{Hydrotreater/Distillation Column Hazard Analysis Report}

Table 3-4. What-If Hazards Analysis Results

\begin{tabular}{|c|c|c|c|c|c|c|c|c|}
\hline \multicolumn{9}{|c|}{$\begin{array}{l}\text { Hydrotreater Process Step 2. Startup/Sulfiding } \\
\text { 1) Clear area of all maintenance work and equipment not compatible with Class } 1 \text { Div } 2 \text { environment. 2) Initiate purge of electrical cabinets and furnace. 3) Put sulfiding tank in place. 4) } \\
\text { Direct product valves to slop tank. 5) Fill pumps with sulfiding solution. 6) Pressurize reactor to operating pressure. 7) Flow hydrogen at sulfiding flowrate and verify offgas handling } \\
\text { system flow. 8) Bring reactor to sulfiding temperature. 9) Begin sulfiding flow. 10) Ramp temperature through sulfiding procedure. 11) Block out and remove sulfiding tank. }\end{array}$} \\
\hline $\begin{array}{l}\text { Hazard } \\
\text { Process }\end{array}$ & & What if: & Hazardous Scenario & $\begin{array}{l}\text { Likeli- } \\
\text { hood }\end{array}$ & Consequences & $\begin{array}{l}\text { Hazard Controls } \\
\text { C = Critical Control }\end{array}$ & & Comments \\
\hline H.2-7 & 5 & $\begin{array}{l}\text { What if there is too } \\
\text { much pressure to V- } \\
125 \text { from nitrogen } \\
\text { pad? }\end{array}$ & $\begin{array}{l}\text { Failure to set low pressure } \\
\text { nitrogen pad pressure } \\
\text { correctly results in } \\
\text { overpressurizing V-125 } \\
\text { with up to } 100 \text { psi of } \\
\text { nitrogen. }\end{array}$ & Likely & $\begin{array}{l}\text { Energetic event - failure of V- } \\
125 \text { vessel pressure boundary. } \\
\text { Flammable atmosphere. } \\
\text { Spill of combustible liquid and } \\
\text { potential creation of flammable } \\
\text { atmosphere. }\end{array}$ & $\begin{array}{l}\text { Pressure regulation of the low } \\
\text { pressure nitrogen supply to } 100 \\
\text { psi. } \\
\text { Pressure regulation of the low } \\
\text { pressure nitrogen system pressure } \\
\text { to } 10 \text { psi. } \\
\text { Design V-125 } 155 \text { psi MAWP } \\
\text { V-125 PRV set at } \leq 100 \text { psi. } \\
\text { Pressure Test Procedure. }\end{array}$ & $\begin{array}{l}\mathrm{C} \\
\mathrm{C}\end{array}$ & \\
\hline H.2-8 & 5 & $\begin{array}{l}\text { What if there is failure } \\
\text { to connect vent line V- } \\
125 \text { to rupture disk? }\end{array}$ & $\begin{array}{l}\text { Failure to connect vent } \\
\text { line to header results in } \\
\text { venting of V-125 contents } \\
\text { to enclosure on system } \\
\text { overpressure/failure of } \\
\text { rupture disk and release of } \\
\text { sulfiding solution } \\
\text { /nitrogen to enclosure } \\
\text { atmosphere. }\end{array}$ & Likely & $\begin{array}{l}\text { Spill of sulfiding solution to } \\
\text { the enclosure. }\end{array}$ & $\begin{array}{l}\text { Procedural step. Connect the } \\
\text { vent line prior to the nitrogen and } \\
\text { outlet. }\end{array}$ & & \\
\hline H.2-9 & 6 & $\begin{array}{l}\text { What if there is failure } \\
\text { to verify pressure and } \\
\text { there is low pressure? }\end{array}$ & $\begin{array}{l}\text { Failure to pressurize the } \\
\text { reactor with nitrogen prior } \\
\text { to starting flow of } \\
\text { hydrogen results in } \\
\text { undetected leak or } \\
\text { unintended flow path. }\end{array}$ & Unlikely & $\begin{array}{l}\text { See other pressure boundary } \\
\text { scenarios. } \\
\text { In no leak, the hydrogen would } \\
\text { pressurize the reactor on } \\
\text { system startup. }\end{array}$ & $\begin{array}{l}\text { Low pressure alarms, procedural } \\
\text { steps. }\end{array}$ & & \\
\hline $\begin{array}{l}\text { H.2- } \\
10\end{array}$ & 6 & $\begin{array}{l}\text { What if there is over } \\
\text { pressurize the system? }\end{array}$ & $\begin{array}{l}\text { Failure to set hydrogen } \\
\text { pressure correctly results } \\
\text { in filling reactor with } \\
3000 \text { psi hydrogen. }\end{array}$ & Unlikely & $\begin{array}{l}\text { Energetic event - over- } \\
\text { pressurization of R-130/V-140 } \\
\text { piping pressure boundary }\end{array}$ & $\begin{array}{l}\text { Design of R-130/V-140 and } \\
\text { component pressure } \geq 3000 \text { psi } \\
\text { MAWP. } \\
\text { R-130/V-140 PRVs set at } 3000 \\
\text { psi. } \\
\text { Pressure regulation of the } \\
\text { hydrogen supply to } 3000 \text { psi. } \\
\text { Pressure regulation of hydrogen } \\
\text { system pressure set at } 2500 \text { psi. } \\
\text { High pressure alarm in R-130. } \\
\text { High-high pressure interlock in } \\
\text { R-130 }\end{array}$ & $\mathrm{C}$ & \\
\hline
\end{tabular}




\section{Hydrotreater/Distillation Column Hazard Analysis Report}

Table 3-4. What-If Hazards Analysis Results

\begin{tabular}{|c|c|c|c|c|c|c|c|}
\hline \multicolumn{2}{|c|}{$\begin{array}{l}\text { Hazard ID/ } \\
\text { Process Step }\end{array}$} & \multirow[t]{2}{*}{ What if: } & \multirow[t]{2}{*}{ Hazardous Scenario } & \multirow[t]{2}{*}{$\begin{array}{l}\text { Likeli- } \\
\text { hood }\end{array}$} & \multirow[t]{2}{*}{ Consequences } & \multirow{2}{*}{ 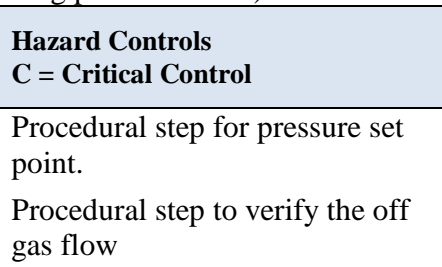 } & \multirow[t]{2}{*}{ Comments } \\
\hline & & & & & & & \\
\hline $\begin{array}{l}\text { H.2- } \\
11\end{array}$ & 8 & $\begin{array}{l}\text { What if the furnace } \\
\text { controller fails high } \\
\text { resulting in too fast } \\
\text { heatup? }\end{array}$ & $\begin{array}{l}\text { Furnace controller fails } \\
\text { high resulting in too fast } \\
\text { heatup with potential } \\
\text { impact to catalyst. }\end{array}$ & Likely & None identified. & $\begin{array}{l}\text { Limited by design of heater such } \\
\text { that the worst case is that you } \\
\text { heat up in allowable range. }\end{array}$ & $\begin{array}{l}\text { The heatup rate is less than } \\
5 \text { degrees } C \text { per minute. }\end{array}$ \\
\hline $\begin{array}{l}\text { H.2- } \\
12\end{array}$ & 8 & $\begin{array}{l}\text { What if the catalyst is } \\
\text { heated above desired } \\
\text { sulfiding temperature? }\end{array}$ & $\begin{array}{l}\text { Failure to stop heating the } \\
\text { reactor at desired } \\
\text { temperature results in start } \\
\text { of sulfiding with catalyst } \\
\text { at higher than desired } \\
\text { temperature. }\end{array}$ & Likely & Process upset to the catalyst. & $\begin{array}{l}\text { Procedural step to monitor } \\
\text { temperature. }\end{array}$ & \\
\hline $\begin{array}{l}\text { H.2- } \\
13\end{array}$ & 8 & $\begin{array}{l}\text { What if there is failure } \\
\text { to heat system up to } \\
\text { desired sulfiding } \\
\text { temperature? }\end{array}$ & $\begin{array}{l}\text { Failure to heat the reactor } \\
\text { to desired sulfiding } \\
\text { temperature results in start } \\
\text { of sulfiding too early with } \\
\text { reactor at lower than } \\
\text { desired temperature. }\end{array}$ & Likely & Process upset to the catalyst. & $\begin{array}{l}\text { Procedural step to monitor } \\
\text { temperature. }\end{array}$ & \\
\hline $\begin{array}{l}\text { H.2- } \\
14\end{array}$ & 9 & $\begin{array}{l}\text { What if flow rate of } \\
\text { sulfide is wrong? }\end{array}$ & $\begin{array}{l}\text { Failure to properly } \\
\text { transfer (flowrate) of the } \\
\text { sulfiding solutions results } \\
\text { in incomplete activation of } \\
\text { catalyst. }\end{array}$ & Likely & Process upset to the catalyst. & Process monitoring. & $\begin{array}{l}\text { Flow rate is limited by the } \\
\text { pump to } 400 \mathrm{ml} / \mathrm{min} \text {. which } \\
\text { would only last } 2.5 \text { minutes }\end{array}$ \\
\hline $\begin{array}{l}\text { H.2- } \\
15\end{array}$ & 9 & $\begin{array}{l}\text { What if valve HV - } \\
2006 \text { is closed? }\end{array}$ & $\begin{array}{l}\text { Failure to open HV-2006 } \\
\text { results in deadheading the } \\
\text { flow with over- } \\
\text { pressurization of the } \\
\text { transfer line (pump } \\
\text { pressure } 4500 \text { psi) } \\
\text { resulting in leak. }\end{array}$ & Likely & $\begin{array}{l}\text { Spray or Spill. High pressure } \\
\text { spray of sulfiding solution. }\end{array}$ & $\begin{array}{l}\text { Transfer Line (tubing) is rated at } \\
4800 \text { psi. } \\
\text { Pressure Indicator PI-2011 } \\
\text { ISCO Pump high pressure set } \\
\text { point (process controlled). } \\
\text { ISCO Pump firmware maximum } \\
\text { pressure of 3750psi. } \\
\text { ISCO Pump shear pin at } 4500 \text { psi }\end{array}$ & \\
\hline $\begin{array}{l}\text { H.2- } \\
16\end{array}$ & 9 & $\begin{array}{l}\text { What if there is a } \\
\text { failure in the pressure } \\
\text { boundary? }\end{array}$ & $\begin{array}{l}\text { Failure in the pressure } \\
\text { boundary results in spray } \\
\text { or leak of sulfiding } \\
\text { solution to the enclosure. }\end{array}$ & $\begin{array}{l}\text { Very } \\
\text { Unlikely }\end{array}$ & $\begin{array}{l}\text { Spray or leak of sulfiding } \\
\text { solution to the enclosure }\end{array}$ & $\begin{array}{l}\text { Pressure Test Procedure. } \\
\text { Design of V-125 and transfer line } \\
\text { components. }\end{array}$ & \\
\hline
\end{tabular}

Page 27 of 98 


\section{Hydrotreater/Distillation Column Hazard Analysis Report}

Table 3-4. What-If Hazards Analysis Results






\section{Hydrotreater/Distillation Column Hazard Analysis Report}

Table 3-4. What-If Hazards Analysis Results

\begin{tabular}{|c|c|c|c|c|c|c|}
\hline \multicolumn{7}{|c|}{$\begin{array}{l}\text { Hydrotreater Process Step 2. Startup/Sulfiding } \\
\text { 1) Clear area of all maintenance work and equipment not compatible with Class } 1 \text { Div } 2 \text { environment. 2) Initiate purge of electrical cabinets and furnace. 3) Put sulfiding tank in place. 4) } \\
\text { Direct product valves to slop tank. 5) Fill pumps with sulfiding solution. 6) Pressurize reactor to operating pressure. 7) Flow hydrogen at sulfiding flowrate and verify offgas handling } \\
\text { system flow. 8) Bring reactor to sulfiding temperature. 9) Begin sulfiding flow. 10) Ramp temperature through sulfiding procedure. 11) Block out and remove sulfiding tank. }\end{array}$} \\
\hline $\begin{array}{l}\text { Haza } \\
\text { Proce }\end{array}$ & What if: & Hazardous Scenario & $\begin{array}{l}\text { Likeli- } \\
\text { hood }\end{array}$ & Consequences & $\begin{array}{l}\text { Hazard Controls } \\
\mathrm{C}=\text { Critical Control }\end{array}$ & Comments \\
\hline $\begin{array}{l}\text { H.2- } \\
23\end{array}$ & $\begin{array}{l}\text { What if there is a } \\
\text { failure in the pressure } \\
\text { boundary (V-125)? }\end{array}$ & $\begin{array}{l}\text { Failure in pressure } \\
\text { boundary (V-125) results } \\
\text { in release of sulfiding } \\
\text { solution (or acetone- } \\
\text { cleanout) and nitrogen to } \\
\text { the enclosure }\end{array}$ & & $\begin{array}{l}\text { Spray or Spill. Spray or leak of } \\
\text { sulfiding solution to the } \\
\text { enclosure } \\
\text { Potential for oxygen deficient } \\
\text { atmosphere. }\end{array}$ & Design of V-125. & \\
\hline $\begin{array}{l}\text { H.2- } \\
24\end{array}$ & $\begin{array}{l}\text { What if there is a } \\
\text { failure in the pressure } \\
\text { boundary (nitrogen)? }\end{array}$ & $\begin{array}{l}\text { Failure in the Low } \\
\text { Pressure Nitrogen } \\
\text { Pressure boundary. }\end{array}$ & & $\begin{array}{l}\text { Exposure of Personnel. } ~ 10-15 \\
\text { psi release of nitrogen to } \\
\text { enclosure, potential for oxygen } \\
\text { deficient atmosphere. Loss of } \\
\text { ability to transfer. }\end{array}$ & $\begin{array}{l}\text { Design of Low Pressure Nitrogen } \\
\text { Piping. }\end{array}$ & \\
\hline $\begin{array}{l}\text { H.2- } \\
25\end{array}$ & $\begin{array}{l}\text { What if there is too } \\
\text { much pressure } \\
\text { (nitrogen)? }\end{array}$ & $\begin{array}{l}\text { Failure to set Low } \\
\text { Pressure Nitrogen Supply } \\
\text { regulator results in over } \\
\text { pressurization of system } \\
\text { and release of nitrogen to } \\
\text { the enclosure. }\end{array}$ & & $\begin{array}{l}\text { Exposure of Personnel } \\
\text { Potential for oxygen deficient } \\
\text { atmosphere }\end{array}$ & $\begin{array}{l}\text { Piping System design pressure is } \\
2500 \text { psi. } \\
\text { PCV-2001 sets pressure to } 10 \\
\text { psi. } \\
\text { Overpressure relief on Supply } \\
\text { system provided by PCV-2030 } \\
\text { (15 psi) vented to offgas vent } \\
\text { header. } \\
\text { Overpressure vented (V-120, V- } \\
\text { 125) through LP relief header. }\end{array}$ & \\
\hline $\begin{array}{l}\text { H.2- } \\
26\end{array}$ & $\begin{array}{l}\text { What if there is too } \\
\text { much pressure } \\
\text { (nitrogen)? }\end{array}$ & $\begin{array}{l}\text { Failure to correctly set } \\
\text { low pressure nitrogen } \\
\text { (PCV-2001) results in } \\
\text { over-pressurization of V- } \\
120 / 125\end{array}$ & $\begin{array}{l}\text { Very } \\
\text { Unlikely }\end{array}$ & $\begin{array}{l}\text { Spray or Spill. Spray or leak of } \\
\text { sulfiding solution to the } \\
\text { enclosure } \\
\text { Potential for oxygen deficient } \\
\text { atmosphere. }\end{array}$ & $\begin{array}{l}\text { Vessel Design V-120, } 135 \text { psi. } \\
\text { Vessel Design V-125, } 155 \text { psi. } \\
\text { Pressure regulation of the low } \\
\text { pressure nitrogen supply to } 100 \\
\text { psi. } \\
\text { Pressure regulation of the low } \\
\text { pressure nitrogen system pressure } \\
\text { to } 10 \text { psi. } \\
\text { Overpressure relief on Supply } \\
\text { system provided by PCV-2030 } \\
\text { (15 psi) vented to offgas vent } \\
\text { header. } \\
\text { Overpressure vented (V-120, V- } \\
\text { 125) through LP relief header. } \\
\text { Overpressure vented through LP } \\
\text { relief header. }\end{array}$ & \\
\hline
\end{tabular}




\section{Hydrotreater/Distillation Column Hazard Analysis Report}

Table 3-4. What-If Hazards Analysis Results

\section{Hydrotreater Process Step 3. Bio-oil feeding}

1) Adjust hydrogen flow and temperature to operating conditions. 2) Fill pumps with bio-oil from feed tank. 3) Start bio-oil supply drum recirculation/take-up loop. 4) Direct product valves to L/L separator and A or B product tanks. 5) Start bio-oil feed at $\sim 30 \%$ of target flowrate. 6) Allow system to equilibrate. 7) Gradually bring reactor to target flowrate.

\begin{tabular}{|c|c|c|c|c|c|c|c|}
\hline $\begin{array}{l}\text { Hazar } \\
\text { Proces } \\
\text { Step }\end{array}$ & & What if: & Hazardous Scenario & $\begin{array}{l}\text { Likeli- } \\
\text { hood }\end{array}$ & Consequences & $\begin{array}{l}\text { Hazard Controls } \\
\text { C = Critical Control }\end{array}$ & Comments \\
\hline $\begin{array}{l}\text { H.3- } \\
1\end{array}$ & 3 & $\begin{array}{l}\text { What if there is failure } \\
\text { to initiate bio-oil supply } \\
\text { from feed drum? }\end{array}$ & $\begin{array}{l}\text { Failure to initiate flow of } \\
\text { bio-oil from feed drum } \\
\text { results inV-120 will } \\
\text { empty during the process. } \\
\text { Nitrogen to the ISCO } \\
\text { pump. }\end{array}$ & Likely & Process impact on loss of feed. & $\begin{array}{l}\text { Low level Interlock V-120. } \\
\text { ISCO pump will shutoff due to } \\
\text { insufficient liquid refill. }\end{array}$ & \\
\hline $\begin{array}{l}\text { H.3- } \\
2\end{array}$ & 4 & $\begin{array}{l}\text { What if there is failure } \\
\text { to realign valves to } \mathrm{L} / \mathrm{L} \\
\text { separator and product } \\
\text { tanks? }\end{array}$ & $\begin{array}{l}\text { Failure to realign valves } \\
\text { results in bypass of LG- } \\
147 \text { (liquid-liquid } \\
\text { separator) with direct } \\
\text { transfer to the V-162 } \\
\text { (slop tank). }\end{array}$ & Likely & $\begin{array}{l}\text { Spray or Spill. Possibility to } \\
\text { overfill the V-162 tank and } \\
\text { overflow V-162 into vent } \\
\text { header, which could plug the } \\
\text { vent and/or low pressure } \\
\text { nitrogen feed. }\end{array}$ & $\begin{array}{l}\text { Tank is designed for full flow } \\
\text { from V-140 (LV-4003). } \\
\text { Procedural check in place. } \\
\text { PSV } 4016 \text { set pressure at 70psi. }\end{array}$ & $\begin{array}{l}\text { Volume of V-162 could } \\
\text { contain overflow for up to } \\
19 \text { hours. }\end{array}$ \\
\hline $\begin{array}{l}\text { H.3- } \\
3\end{array}$ & 4 & $\begin{array}{l}\text { What if there is failure } \\
\text { to align } 3 \text { way valve to } \\
\text { product tanks? } \\
\text { Deadhead }\end{array}$ & $\begin{array}{l}\text { Failure to align } 3 \text { way } \\
\text { valve to product tanks } \\
\text { results in deadhead on } \\
\text { line and overfill of LG- } \\
147 .\end{array}$ & Likely & $\begin{array}{l}\text { Spray or Spill. Potential to } \\
\text { overflow to product gas header } \\
\text { and plug (V-153 or WTM-152). }\end{array}$ & $\begin{array}{l}\text { LG-147 visual indication during } \\
\text { operator rounds. } \\
\text { Product scales on V-160 and V- } \\
161 . \\
\text { Local indication on wet WTM- } \\
152 \text { test meter. } \\
\text { Relief valves on product gas } \\
\text { header at } 10 \text { psi. } \\
\text { Relief Valve on LG-147 feed line } \\
\text { at } 70 \text { psi. }\end{array}$ & \\
\hline $\begin{array}{l}\text { H.3- } \\
4\end{array}$ & 4 & $\begin{array}{l}\text { What if you align to a } \\
\text { product tank that is } \\
\text { already full? }\end{array}$ & $\begin{array}{l}\text { Operator aligns to a } \\
\text { "full” product tank } \\
\text { resulting in overfill the } \\
\text { product tank. }\end{array}$ & Likely & $\begin{array}{l}\text { Spray or Spill. Overfill tank } \\
\text { with potential overflow to } \\
\text { product gas header line and plug } \\
\text { (V-153 or WTM-152). }\end{array}$ & $\begin{array}{l}\text { LG-147 visual indication during } \\
\text { operator rounds. } \\
\text { Product scales on V-160 and V- } \\
161 . \\
\text { Local indication on wet WTM- } \\
152 \text { test meter. } \\
\text { Relief valves on product gas } \\
\text { header at } 10 \text { psi. } \\
\text { Relief Valves on V-160A/B and } \\
\text { V-161A/B set at } 70 \text { psi. } \\
\text { Relief Valve on LG-147 feed line } \\
\text { at } 70 \text { psi. }\end{array}$ & \\
\hline
\end{tabular}




\section{Hydrotreater/Distillation Column Hazard Analysis Report}

Table 3-4. What-If Hazards Analysis Results






\section{Hydrotreater/Distillation Column Hazard Analysis Report}

Table 3-4. What-If Hazards Analysis Results

\begin{tabular}{|c|c|c|c|c|c|c|c|c|}
\hline \multicolumn{9}{|c|}{$\begin{array}{l}\text { Hydrotreater Process Step 4. Operation } \\
\text { 1) Monitor feed and product levels. 2) When product drums are at } 85 \text { to } 90 \% \text { full, switch to other product tanks. 3) Download water vessel to product container. 4) Download oil vessel to } \\
\text { product container or transfer to still skid feed tank. }\end{array}$} \\
\hline $\begin{array}{l}\text { Hazard } \\
\text { Process } \\
\text { Step }\end{array}$ & & What if: & Hazardous Scenario & $\begin{array}{l}\text { Likeli- } \\
\text { hood }\end{array}$ & Consequences & $\begin{array}{l}\text { Hazard Controls } \\
\text { C = Critical Control }\end{array}$ & & Comments \\
\hline H.4-1 & 1 & $\begin{array}{l}\text { What if the ISCO } \\
\text { pump freezes (open } \\
\text { valves). }\end{array}$ & $\begin{array}{l}\text { Failure in ISCO pumping } \\
\text { results in liquid backflow } \\
\text { from reactor. (Check } \\
\text { valves are assumed to leak } \\
\text { and upstream vessels } \\
\text { subject to hydrogen } \\
\text { backflow). } \\
\end{array}$ & Unlikely & $\begin{array}{l}\text { Energetic event- } \\
\text { Pressurization of V-120 }\end{array}$ & $\begin{array}{l}\text { PSE2005 @ } 100 \text { psi sized for } \\
\text { backflow. } \\
\text { Check Valve (CK-2007) }\end{array}$ & $\mathrm{C}$ & \\
\hline H.4-2 & 1 & $\begin{array}{l}\text { What if the pumps run } \\
\text { in phase? Will they } \\
\text { cause problems? }\end{array}$ & $\begin{array}{l}\text { Failure in pumping control } \\
\text { (synchronized) results in } \\
\text { exothermic reaction. } \\
\text { [If combined with a plug - } \\
\text { refer to H.4-7] }\end{array}$ & Likely & $\begin{array}{l}\text { Process Upset. Local } \\
\text { temperature increase slight } \\
\text { pressure increase. } \\
\text { Refer to H.4-7 }\end{array}$ & $\begin{array}{l}\text { Limited to } 1 \text { liter due to design of } \\
\text { pumps. System would slow } \\
\text { down and not get as much. It } \\
\text { would not refill and shut off. } \\
\text { See hazard controls for the } \\
\text { exothermic event H.4-7 }\end{array}$ & & $\begin{array}{l}\text { Flow rate is limited by the } \\
\text { pump to } 400 \mathrm{ml} / \text { min. } \\
\text { which would only last } 2.5 \\
\text { minutes }\end{array}$ \\
\hline H.4-3 & 1 & $\begin{array}{l}\text { What if the pumps run } \\
\text { in phase? Will they } \\
\text { cause problems? }\end{array}$ & $\begin{array}{l}\text { Failure in pumping control } \\
\text { (synchronized) results in } \\
\text { excessive flow of bio-oil } \\
\text { to Flood the catalyst bed } \\
\text { with bio-oil. }\end{array}$ & Likely & $\begin{array}{l}\text { Process Upset. Pressurization } \\
\text { of system due to plugging by } \\
\text { high viscosity product. }\end{array}$ & $\begin{array}{l}\text { Limited to } 1 \text { liter due to design of } \\
\text { pumps. Design of the system for } \\
\text { full pressure to receive on this } \\
\text { scenario. }\end{array}$ & & \\
\hline H.4-4 & 1 & $\begin{array}{l}\text { What if there is a leak } \\
\text { in the ISCO pump? }\end{array}$ & $\begin{array}{l}\text { Seal on piston and/or } \\
\text { pump leak results in } \\
\text { release of Bio-oil to the } \\
\text { enclosure.. }\end{array}$ & Likely & $\begin{array}{l}\text { Spray or Spill. Release of Bio- } \\
\text { oil to the enclosure. }\end{array}$ & $\begin{array}{l}\text { There is a catch under the seal } \\
\text { and it would run down a tube into } \\
\text { a small bottle or built in } \\
\text { secondary container. For large } \\
\text { leak pumps would run out of } \\
\text { phase and shut down. }\end{array}$ & & $\begin{array}{l}\text { Flow rate is limited by the } \\
\text { pump to } 400 \mathrm{ml} / \mathrm{min} \text {. } \\
\text { which would only last } 2.5 \\
\text { minutes }\end{array}$ \\
\hline H.4-5 & 1 & $\begin{array}{l}\text { What if there is a leak } \\
\text { in the ISCO pump? }\end{array}$ & $\begin{array}{l}\text { Seal on piston and pump } \\
\text { leak with backflow of } \\
\text { hydrogen through check } \\
\text { valves. }\end{array}$ & Unlikely & $\begin{array}{l}\text { Spray or Spill. Release of Bio- } \\
\text { oil and hydrogen to the } \\
\text { enclosure. }\end{array}$ & $\begin{array}{l}\text { There is a catch under the seal } \\
\text { and it would run down a tube into } \\
\text { a small bottle or built in } \\
\text { secondary container. For large } \\
\text { leak pumps would run out of } \\
\text { phase and shut down. Ventilation } \\
\text { of enclosure, hydrogen monitors } \\
\text { on skid and enclosure.. }\end{array}$ & & \\
\hline
\end{tabular}




\section{Hydrotreater/Distillation Column Hazard Analysis Report}

Table 3-4. What-If Hazards Analysis Results

\begin{tabular}{|c|c|c|c|c|c|c|c|c|}
\hline \multicolumn{9}{|c|}{$\begin{array}{l}\text { Hydrotreater Process Step 4. Operation } \\
\text { 1) Monitor feed and product levels. 2) When product drums are at } 85 \text { to } 90 \% \text { full, switch to other product tanks. 3) Download water vessel to product container. 4) Download oil vessel to } \\
\text { product container or transfer to still skid feed tank. }\end{array}$} \\
\hline \multicolumn{2}{|c|}{$\begin{array}{l}\text { Hazard ID/ } \\
\text { Process } \\
\text { Step }\end{array}$} & \multirow{2}{*}{$\begin{array}{l}\text { What if: } \\
\text { What if there is } \\
\text { excessive pressure in } \\
\text { the reactor? }\end{array}$} & \multirow{2}{*}{$\begin{array}{l}\text { Hazardous Scenario } \\
\text { There is a plug in the } \\
\text { system and we continue to } \\
\text { pump (normal operation), } \\
\text { challenging the pressure } \\
\text { boundary of the system. }\end{array}$} & \multirow{2}{*}{$\begin{array}{l}\text { Likeli- } \\
\text { hood }\end{array}$} & \multirow{2}{*}{$\begin{array}{l}\text { Consequences } \\
\text { Energetic event failure of } \\
\text { Reactor }\end{array}$} & \multirow[b]{2}{*}{$\begin{array}{l}\text { Hazard Controls } \\
\text { C = Critical Control } \\
\text { R-130 Design pressure } 3000 \text { psi } \\
\text { Pressure relief valve set at } 3000 \\
\text { psi. } \\
\text { ISCO Pump high pressure set } \\
\text { point (process controlled). ISCO } \\
\text { Pump firmware maximum } \\
\text { pressure of } 3750 \text { psi. } \\
\text { ISCO Pump shear pin at } 4500 \text { psi. } \\
\text { Pressure set point on hydrogen } \\
\text { system (3000 psi). } \\
\text { High-High pressure interlock at } \\
2700 \text { psi. } \\
\text { Process control alarms for high } \\
\text { pressure. }\end{array}$} & \multirow[b]{2}{*}{$\begin{array}{l}\mathrm{C} \\
\mathrm{C}\end{array}$} & \multirow[t]{2}{*}{ Comments } \\
\hline H.4-6 & 1 & & & & & & & \\
\hline H.4-7 & 1 & $\begin{array}{l}\text { What if there is an } \\
\text { excessive exothermic } \\
\text { reaction resulting in } \\
\text { the pressure increase? }\end{array}$ & $\begin{array}{l}\text { Exothermic reaction in } \\
\text { reactor column combined } \\
\text { with a plug, results in } \\
\text { challenging the pressure } \\
\text { boundary of the system. }\end{array}$ & Unlikely & $\begin{array}{l}\text { Energetic event failure of } \\
\text { Reactor }\end{array}$ & $\begin{array}{l}\text { R-130 Design pressure } 3000 \text { psi } \\
\text { Pressure relief valve set at } 3000 \\
\text { psi. } \\
\text { Pressure set point on hydrogen } \\
\text { system ( } 3000 \text { psi). } \\
\text { High-High pressure interlock at } \\
2700 \text { psi. } \\
\text { ISCO Pump high pressure set } \\
\text { point (process controlled). } \\
\text { ISCO Pump firmware maximum } \\
\text { pressure of } 3750 \text { psi. } \\
\text { ISCO Pump shear pin at } 4500 \text { psi. } \\
\text { Process control alarms for high } \\
\text { pressure } \\
\text { Procedural step. There is } \\
\text { temperature and feedback to the } \\
\text { operator. Audible alarms on } \\
\text { internal thermocouples. }\end{array}$ & \begin{tabular}{l|}
$\mathrm{C}$ \\
$\mathrm{C}$
\end{tabular} & $\begin{array}{l}\text { Operator Response to } \\
\text { audible alarm should be to } \\
\text { turn off the bio-oil feed } \\
\text { and/or the hydrogen. }\end{array}$ \\
\hline
\end{tabular}




\section{Hydrotreater/Distillation Column Hazard Analysis Report}

Table 3-4. What-If Hazards Analysis Results

\begin{tabular}{|c|c|c|c|c|c|c|c|}
\hline \multicolumn{8}{|c|}{$\begin{array}{l}\text { Hydrotreater Process Step 4. Operation } \\
\text { 1) Monitor feed and product levels. 2) When product drums are at } 85 \text { to } 90 \% \text { full, switch to other product tanks. 3) Download water vessel to product container. 4) Download oil vessel to } \\
\text { product container or transfer to still skid feed tank. }\end{array}$} \\
\hline $\begin{array}{l}\text { Hazard ID/ } \\
\text { Process } \\
\text { Step }\end{array}$ & What if: & Hazardous Scenario & $\begin{array}{l}\text { Likeli- } \\
\text { hood }\end{array}$ & Consequences & $\begin{array}{l}\text { Hazard Controls } \\
\mathrm{C}=\text { Critical Control }\end{array}$ & & Comments \\
\hline H.4-8 & $\begin{array}{l}\text { What if there is a } \\
\text { failure in the reactor } \\
\text { vessel? }\end{array}$ & $\begin{array}{l}\text { Material failure (e.g. } \\
\text { design flaw, undetected } \\
\text { flaw) or leak at the flange } \\
\text { connection at head } \\
\text { connections or a failure at } \\
\text { the weld results in a spray } \\
\text { leak }\end{array}$ & Unlikely & $\begin{array}{l}\text { Flammable atmosphere. } \\
\text { High pressure release to } \\
\text { enclosure (steam, hydrogen, } \\
\text { or hydrocarbons) }\end{array}$ & $\begin{array}{l}\text { R-130 Design } \\
\text { Routine internal inspection } \\
\text { vessel. } \\
\text { Pressure Test Procedure. } \\
\text { Operating within design } \\
\text { parameters-overpressure over- } \\
\text { temperature alarms and controls. } \\
\text { Enclosure Design - Class } 1 \text { Div } \\
2 . \\
\text { Enclosure Ventilation System. } \\
\text { Hydrogen monitors on skid and } \\
\text { in enclosure. } \\
\text { Flammable vapor monitor on } \\
\text { skid. } \\
\text { Expanded metal screen and } \\
\text { acrylic shield on walkway on } \\
\text { north side of flange. Graylock } \\
\text { around flange would generally } \\
\text { stop direct steam impingement. }\end{array}$ & $\begin{array}{l}\mathrm{C} \\
\mathrm{C} \\
\mathrm{C} \\
\mathrm{C}\end{array}$ & \\
\hline H.4-9 & $\begin{array}{l}\text { What if there is a } \\
\text { failure in the reactor } \\
\text { vessel. }\end{array}$ & $\begin{array}{l}\text { Material failure (e.g. } \\
\text { design flaw, undetected } \\
\text { flaw) results in } \\
\text { catastrophic failure of the } \\
\text { vessel }\end{array}$ & $\begin{array}{l}\text { Very } \\
\text { Unlikely }\end{array}$ & $\begin{array}{l}\text { Energetic event - failure of } \\
\text { Reactor }\end{array}$ & $\begin{array}{l}\text { R-130 Design } \\
\text { Routine internal inspection } \\
\text { vessel. } \\
\text { Pressure Test Procedure. } \\
\text { Operating within design } \\
\text { parameters - overpressure over } \\
\text { temperature alarms and controls. }\end{array}$ & C & \\
\hline
\end{tabular}




\section{Hydrotreater/Distillation Column Hazard Analysis Report}

Table 3-4. What-If Hazards Analysis Results

\begin{tabular}{|c|c|c|c|c|c|c|c|}
\hline \multicolumn{8}{|c|}{$\begin{array}{l}\text { Hydrotreater Process Step 4. Operation } \\
\text { 1) Monitor feed and product levels. 2) When product drums are at } 85 \text { to } 90 \% \text { full, switch to other product tanks. 3) Download water vessel to product container. 4) Download oil vessel to } \\
\text { product container or transfer to still skid feed tank. }\end{array}$} \\
\hline $\begin{array}{l}\text { Hazard ID/ } \\
\text { Process } \\
\text { Step }\end{array}$ & What if: & Hazardous Scenario & $\begin{array}{l}\text { Likeli- } \\
\text { hood }\end{array}$ & Consequences & $\begin{array}{l}\text { Hazard Controls } \\
\mathrm{C}=\text { Critical Control }\end{array}$ & & Comments \\
\hline $\begin{array}{l}\text { H.4- } \\
10\end{array}$ & $\begin{array}{l}\text { What if there is flame } \\
\text { impingement due to } \\
\text { hydrogen leak. }\end{array}$ & $\begin{array}{l}\text { Catastrophic failure of the } \\
\text { reactor vessel due to flame } \\
\text { impingement from a } \\
\text { hydrogen fire (hydrogen } \\
\text { line break) results in loss } \\
\text { of pressure integrity. }\end{array}$ & $\begin{array}{l}\text { Extremely } \\
\text { Unlikely }\end{array}$ & $\begin{array}{l}\text { Energetic event - failure of } \\
\text { Reactor }\end{array}$ & $\begin{array}{l}\text { Design of hydrogen pipe system. } \\
\text { Excess flow valve on hydrogen } \\
\text { supply. } \\
\text { Flame detection inside enclosure. } \\
\text { Hydrogen monitor on skid and } \\
\text { enclosure. } \\
\text { Fire suppression system in } \\
\text { enclosure. } \\
\text { Reactor column shielded by } \\
\text { furnace enclosure which would } \\
\text { limit exposure and rapid } \\
\text { temperature rise to heat up the } \\
\text { vessel. } \\
\text { Operator response and emergency } \\
\text { stop. }\end{array}$ & $\begin{array}{l}\mathrm{C} \\
\mathrm{C}\end{array}$ & \\
\hline $\begin{array}{l}\text { H.4- } \\
11\end{array}$ & $\begin{array}{l}\text { What if there is a } \\
\text { flame impingement } \\
\text { due to a flammable } \\
\text { liquid fire? }\end{array}$ & $\begin{array}{l}\text { Catastrophic failure of the } \\
\text { reactor due to Flame } \\
\text { impingement from a } \\
\text { flammable liquid fire } \\
\text { results in loss of pressure } \\
\text { integrity. }\end{array}$ & $\begin{array}{l}\text { Extremely } \\
\text { Unlikely }\end{array}$ & $\begin{array}{l}\text { Energetic event - failure of } \\
\text { Reactor }\end{array}$ & $\begin{array}{l}\text { Design of Product Tank (V-160 } \\
\text { A/B). } \\
\text { Pressure Test Procedure. } \\
\text { Distillation skid has separate } \\
\text { containment from the } \\
\text { hydrotreater skid. } \\
\text { Enclosure Design - Class } 1 \text { Div } 2 \\
\text { Flammable vapor monitor on skid } \\
\text { Flame detection inside enclosure. } \\
\text { Fire suppression system in } \\
\text { enclosure } \\
\text { Reactor column is shielded by } \\
\text { furnace enclosure which would } \\
\text { limit exposure and rapid } \\
\text { temperature rise to heat up the } \\
\text { vessel. } \\
\text { Operator response and emergency } \\
\text { stop. }\end{array}$ & $\mathrm{C}$ & $\begin{array}{l}\text { Event may be incredible } \\
\text { based on lack of quantity or } \\
\text { heat energy from a pool fire. } \\
\text { Size of product tank. V- } \\
\text { 160A/B is } 19 \text { liters. This is } \\
\text { a day's worth of running } \\
\text { production at } 1-2 \text { liter/hr (38 } \\
\text { liters total volume of both } \\
\text { product tanks). }\end{array}$ \\
\hline
\end{tabular}




\section{Hydrotreater/Distillation Column Hazard Analysis Report}

Table 3-4. What-If Hazards Analysis Results

\begin{tabular}{|c|c|c|c|c|c|c|}
\hline \multicolumn{7}{|c|}{$\begin{array}{l}\text { Hydrotreater Process Step 4. Operation } \\
\text { 1) Monitor feed and product levels. 2) When product drums are at } 85 \text { to } 90 \% \text { full, switch to other product tanks. 3) Download water vessel to product container. 4) Download oil vessel to } \\
\text { product container or transfer to still skid feed tank. }\end{array}$} \\
\hline $\begin{array}{l}\text { Hazard ID/ } \\
\text { Process } \\
\text { Step }\end{array}$ & What if: & Hazardous Scenario & $\begin{array}{l}\text { Likeli- } \\
\text { hood }\end{array}$ & Consequences & $\begin{array}{l}\text { Hazard Controls } \\
\text { C = Critical Control }\end{array}$ & Comments \\
\hline $\begin{array}{l}\text { H.4- } \\
12\end{array}$ & $\begin{array}{l}\text { What if we lose } \\
\text { hydrogen flow to the } \\
\text { reactor? }\end{array}$ & $\begin{array}{l}\text { Loss of hydrogen pressure } \\
\text { results in process upset (no } \\
\text { reaction) and pressure } \\
\text { decrease over time. } \\
\text { If continued filling of the } \\
\text { reactor with bio-oil } \\
\text { occurred, the potential for } \\
\text { subsequent plugging- once } \\
\text { you plug the reactor you } \\
\text { could over pressurize - } \\
\text { this would require a long } \\
\text { time. }\end{array}$ & Likely & $\begin{array}{l}\text { Process upset. Loss of } \\
\text { product quality. } \\
\text { Overpressurization. See } \\
\text { energetic Reactor } \\
\text { overpressure events. }\end{array}$ & $\begin{array}{l}\text { L/L mass flow alarm and an } \\
\text { interlock to shut off hydrogen and } \\
\text { the ISCO pump. } \\
\text { There is also a low mass flow } \\
\text { alarm. } \\
\text { Procedural monitoring of system. }\end{array}$ & $\begin{array}{l}\text { System not set to shut down } \\
\text { or trip. It would keep } \\
\text { running for a while due to } \\
\text { low usage }\end{array}$ \\
\hline $\begin{array}{l}\text { H.4- } \\
13\end{array}$ & $\begin{array}{l}\text { What if you lose } \\
\text { heaters? }\end{array}$ & $\begin{array}{l}\text { Loss of heat input } \\
\text { resulting in incomplete } \\
\text { reaction. } \\
\text { If continued filling of the } \\
\text { reactor with bio-oil } \\
\text { occurred there is the } \\
\text { potential for subsequent } \\
\text { plugging- once you plug } \\
\text { the reactor you could over } \\
\text { pressurize - this would } \\
\text { require a long time. }\end{array}$ & Likely & $\begin{array}{l}\text { Process upset. Loss of } \\
\text { product quality. } \\
\text { Overpressurization. See } \\
\text { energetic Reactor } \\
\text { overpressure events. }\end{array}$ & $\begin{array}{l}\text { Sufficient time for Operator } \\
\text { response. } \\
\text { Process indicators. }\end{array}$ & \\
\hline $\begin{array}{l}\text { H.4- } \\
14\end{array}$ & $\begin{array}{l}\text { What if you misalign } \\
\text { thermo couples to } \\
\text { zone? }\end{array}$ & $\begin{array}{l}\text { Operator moves the } \\
\text { thermocouple tree out of } \\
\text { alignment with the reactor } \\
\text { heating zone resulting in } \\
\text { unstable furnace control. }\end{array}$ & Likely & $\begin{array}{l}\text { Process upset. Loss of } \\
\text { product quality }\end{array}$ & $\begin{array}{l}\text { Administrative controls. } \\
\text { Indicator on shell would indicate } \\
\text { over temperature condition on } \\
\text { one zone. On large temperature } \\
\text { differential between the center } \\
\text { and the shell controller would } \\
\text { ramp heater output down. }\end{array}$ & \\
\hline
\end{tabular}




\section{Hydrotreater/Distillation Column Hazard Analysis Report}

Table 3-4. What-If Hazards Analysis Results

\begin{tabular}{|c|c|c|c|c|c|c|c|}
\hline \multicolumn{8}{|c|}{$\begin{array}{l}\text { Hydrotreater Process Step 4. Operation } \\
\text { 1) Monitor feed and product levels. 2) When product drums are at } 85 \text { to } 90 \% \text { full, switch to other product tanks. 3) Download water vessel to product container. 4) Download oil vessel to } \\
\text { product container or transfer to still skid feed tank. }\end{array}$} \\
\hline $\begin{array}{l}\text { Hazard ID/ } \\
\text { Process } \\
\text { Step }\end{array}$ & What if: & Hazardous Scenario & $\begin{array}{l}\text { Likeli- } \\
\text { hood }\end{array}$ & Consequences & $\begin{array}{l}\text { Hazard Controls } \\
\mathrm{C}=\text { Critical Control }\end{array}$ & & Comments \\
\hline $\begin{array}{l}\text { H.4- } \\
15\end{array}$ & $\begin{array}{l}\text { What if the thermowell } \\
\text { fails? }\end{array}$ & $\begin{array}{l}\text { Failure of thermowell } \\
\text { pressure boundary results } \\
\text { in spray leak }\end{array}$ & Unlikely & $\begin{array}{l}\text { Flammable atmosphere. } \\
\text { Steam, flammable vapor, } \\
\text { hydrogen, potential liquid leak } \\
\text { to the enclosure. }\end{array}$ & $\begin{array}{l}\text { Preventative maintenance and } \\
\text { inspection. Routine internal } \\
\text { inspection vessel. } \\
\text { Design of R-130 (including } \\
\text { thermowell). } \\
\text { Pressure Test Procedure. } \\
\text { Operating within design } \\
\text { parameters - overpressure over- } \\
\text { temperature alarms and controls. } \\
\text { Enclosure Design -Class } 1 \text { Div } 2 . \\
\text { Enclosure Ventilation System. } \\
\text { Hydrogen monitors on skid and } \\
\text { in enclosure. } \\
\text { Flammable vapor monitor on } \\
\text { skid. } \\
\text { Thermo-well is replaceable. }\end{array}$ & $\mathrm{C}$ & $\begin{array}{l}\text {.Release is directed away } \\
\text { from personnel. } \\
\text { Thermowell pressure } \\
\text { boundary is a robust system } \\
\text { but was qualitatively judged } \\
\text { to be more susceptible to } \\
\text { leaks than the Reactor } \\
\text { Vessel. }\end{array}$ \\
\hline $\begin{array}{l}\text { H.4- } \\
16\end{array}$ & $\begin{array}{l}\text { What if we have high } \\
\text { pressure associated } \\
\text { with this portion of the } \\
\text { separator? }\end{array}$ & $\begin{array}{l}\text { Blockage of flow path (F- } \\
143 \text { or F-4019) results in } \\
\text { high pressure in separator. }\end{array}$ & Likely & $\begin{array}{l}\text { Process Upset. Partial } \\
\text { blockage of flow and } \\
\text { pressurization of reactor. } \\
\text { Overfill of V-140 could divert } \\
\text { the liquid to the gas system } \\
\text { causing it to plug also. }\end{array}$ & $\begin{array}{l}\text { Design of High pressure } \\
\text { components. } \\
\text { Pressure Relief Valve PSV-4002 } \\
\text { set at } 3000 \text { psi. } \\
\text { Level control on V-140. Pressure } \\
\text { indicators and alarms. } \\
\text { Pressurization controls from } \\
\text { reactor. }\end{array}$ & & \\
\hline $\begin{array}{l}\text { H.4- } \\
17\end{array}$ & $\begin{array}{l}\text { What if we have high } \\
\text { pressure associated } \\
\text { with this portion of the } \\
\text { separator? }\end{array}$ & $\begin{array}{l}\text { Blockage of flow path (F- } \\
143 \text { or F-4019) results in } \\
\text { high pressure in separator. }\end{array}$ & Unlikely & $\begin{array}{l}\text { Total blockage of flow, } \\
\text { pressurization of system (back } \\
\text { to reactor). }\end{array}$ & $\begin{array}{l}\text { Design V-140 - } 3000 \text { psi MAWP } \\
\text { Pressure Relief Valve PSV-4002 } \\
\text { set at } 3000 \text { psi. } \\
\text { Level control on V-140. Pressure } \\
\text { indicators and alarms. } \\
\text { Overpressurization controls from } \\
\text { reactor. }\end{array}$ & $\mathrm{C}$ & \\
\hline $\begin{array}{l}\text { H.4- } \\
18\end{array}$ & $\begin{array}{l}\text { What if we have } \\
\text { failure of system } \\
\text { boundary V-140/LG- } \\
142 \text { ? }\end{array}$ & $\begin{array}{l}\text { Material failure (e.g. } \\
\text { design flaw, undetected } \\
\text { flaw) results in failure of } \\
\text { V-140 pressure integrity. }\end{array}$ & $\begin{array}{l}\text { Very } \\
\text { Unlikely }\end{array}$ & $\begin{array}{l}\text { Energetic event - failure in V- } \\
\text { 140/LG-142 pressure } \\
\text { boundary. }\end{array}$ & $\begin{array}{l}\text { Design of V-140/LG-142 } \\
\text { Level control on V-140. } \\
\text { Pressure indicators and alarms. } \\
\text { Pressure Test Procedure. }\end{array}$ & $\mathrm{C}$ & \\
\hline
\end{tabular}




\section{Hydrotreater/Distillation Column Hazard Analysis Report}

Table 3-4. What-If Hazards Analysis Results

\begin{tabular}{|c|c|c|c|c|c|c|c|}
\hline \multicolumn{8}{|c|}{$\begin{array}{l}\text { Hydrotreater Process Step 4. Operation } \\
\text { 1) Monitor feed and product levels. 2) When product drums are at } 85 \text { to } 90 \% \text { full, switch to other product tanks. 3) Download water vessel to product container. 4) Download oil vessel to } \\
\text { product container or transfer to still skid feed tank. }\end{array}$} \\
\hline $\begin{array}{l}\text { Hazard ID/ } \\
\text { Process } \\
\text { Step }\end{array}$ & What if: & Hazardous Scenario & $\begin{array}{l}\text { Likeli- } \\
\text { hood }\end{array}$ & Consequences & $\begin{array}{l}\text { Hazard Controls } \\
\text { C = Critical Control }\end{array}$ & & Comments \\
\hline $\begin{array}{l}\text { H.4- } \\
19\end{array}$ & $\begin{array}{l}\text { What if we have } \\
\text { failure of LG-142? }\end{array}$ & $\begin{array}{l}\text { Material failure (e.g. } \\
\text { design flaw, undetected } \\
\text { flaw) results in failure of } \\
\text { LG-142 pressure integrity }\end{array}$ & Unlikely & $\begin{array}{l}\text { Flammable atmosphere. } \\
\text { Release steam, and flammable } \\
\text { vapors, treated bio-oil to } \\
\text { enclosure. Bound by line } \\
\text { shear. }\end{array}$ & $\begin{array}{l}\text { Robust design for glass } \\
\text { components. } \\
\text { Pressure indicators and alarms. } \\
\text { Pressure Test Procedure. }\end{array}$ & $\mathrm{C}$ & \\
\hline $\begin{array}{l}\text { H.4- } \\
20\end{array}$ & $\begin{array}{l}\text { What if we have } \\
\text { failure of high pressure } \\
\text { piping (leak/ spray)? }\end{array}$ & $\begin{array}{l}\text { Material failure (e.g. } \\
\text { design flaw, undetected } \\
\text { flaw) or leak at a flange } \\
\text { Gasket failure, swagelock } \\
\text { leak results in a spray leak. }\end{array}$ & Unlikely & $\begin{array}{l}\text { Flammable atmosphere. } \\
\text { Release steam, hydrogen and } \\
\text { flammable vapors, treated bio- } \\
\text { oil to enclosure. }\end{array}$ & $\begin{array}{l}\text { Design high pressure } \\
\text { components. } \\
\text { Pressure Test Procedure. } \\
\text { Operating within design } \\
\text { parameters } \\
\text { Enclosure Design -Class } 1 \text { Div } 2 . \\
\text { Enclosure Ventilation System. } \\
\text { Hydrogen monitors on skid and } \\
\text { in enclosure. } \\
\text { Flammable vapor monitor skid. }\end{array}$ & $\mathrm{C}$ & \\
\hline $\begin{array}{l}\text { H.4- } \\
21\end{array}$ & $\begin{array}{l}\text { What if there is a low } \\
\text { failure in LIT-4003? }\end{array}$ & $\begin{array}{l}\text { LIT- } 4003 \text { fails low } \\
\text { resulting in closing LV- } \\
4003 \text { which stops the } \\
\text { aqueous flow and } \\
\text { increases the liquid level } \\
\text { in V-140. }\end{array}$ & Likely & $\begin{array}{l}\text { Process upset. Partial } \\
\text { blockage of flow and } \\
\text { pressurization of reactor. } \\
\text { Overfill of V-140 could divert } \\
\text { the liquid to the gas system } \\
\text { causing it to plug also. }\end{array}$ & $\begin{array}{l}\text { Operator response to the low low } \\
\text { alarm on the level indicator LIT- } \\
4003 . \text { Visual inspection of LG- } \\
142 . \\
\text { Pressure indicators and alarms. } \\
\text { Pressurization controls from } \\
\text { reactor. }\end{array}$ & & \\
\hline $\begin{array}{l}\text { H.4- } \\
22\end{array}$ & $\begin{array}{l}\text { What if higher than } \\
\text { expected pressure } \\
\text { downstream of } \\
\text { LV4003? }\end{array}$ & $\begin{array}{l}\text { Failure of LV-4003(full } \\
\text { open) or failure/opening of } \\
\text { the bypass line results in } \\
\text { over pressurization of LG- } \\
147 \text { or low pressure } \\
\text { components downstream }\end{array}$ & Likely & $\begin{array}{l}\text { Energetic event - failure of } \\
\text { pressure boundary (LG-147) } \\
\text { and release of bio-oil to } \\
\text { enclosure. }\end{array}$ & $\begin{array}{l}\text { PSV-4016 set at 70psi. } \\
\text { LG-147 designed at } 100 \text { psig } \\
\text { MAWP. } \\
\text { LG-147 vented to product gas } \\
\text { header. } \\
\text { PSV-5001 in product gas vent } \\
\text { header downstream of LG-147 is } \\
\text { set at 10psi. }\end{array}$ & $\begin{array}{l}\mathrm{C} \\
\mathrm{C}\end{array}$ & \\
\hline
\end{tabular}




\section{Hydrotreater/Distillation Column Hazard Analysis Report}

Table 3-4. What-If Hazards Analysis Results

\begin{tabular}{|c|c|c|c|c|c|c|c|}
\hline \\
\hline $\begin{array}{l}\text { Hazard ID/ } \\
\text { Process } \\
\text { Step }\end{array}$ & What if: & Hazardous Scenario & $\begin{array}{l}\text { Likeli- } \\
\text { hood }\end{array}$ & Consequences & $\begin{array}{l}\text { Hazard Controls } \\
\text { C = Critical Control }\end{array}$ & & Comments \\
\hline $\begin{array}{l}\text { H.4- } \\
23\end{array}$ & $\begin{array}{l}\text { What if higher than } \\
\text { expected pressure } \\
\text { downstream } \\
\text { PCV4007? }\end{array}$ & $\begin{array}{l}\text { Failure of PCV-4007 (full } \\
\text { open) or failure/opening of } \\
\text { the bypass line results in } \\
\text { over pressurization of } \\
\text { product off gas header and } \\
\text { failure of downstream } \\
\text { components }{ }^{2} \text { due to high } \\
\text { velocity flow (Impact to } \\
\text { Wet Test Meter). }\end{array}$ & Likely & $\begin{array}{l}\text { Flammable atmosphere. } \\
\text { Release of hydrogen or } \\
\text { flammable vapors to enclosure } \\
\text { but although most likely } \\
\text { would vent through stack or } \\
\text { back pressure through vented } \\
\text { vessels and pressure relief to } \\
\text { LP Relief Header. } \\
\text { Ultimately drop reactor } \\
\text { pressure. }\end{array}$ & $\begin{array}{l}\text { The badger valve (PV-4005) } \\
\text { would try to control the pressure. } \\
\text { PSV-5001 set at } 10 \text { psi. } \\
\text { Vent system flow path design } \\
\text { (1/2 or greater SS Tubing. } \\
\text { Low alarm at PIT-4005 and PIT- } \\
3001 \text {. } \\
\text { Design of vent system. } \\
\text { Enclosure Design - Class } 1 \text { Div } 2 \\
\text { Enclosure Ventilation System. }\end{array}$ & $\begin{array}{l}\mathrm{C} \\
\mathrm{C}\end{array}$ & \\
\hline $\begin{array}{l}\text { H.4- } \\
24\end{array}$ & $\begin{array}{l}\text { What if high pressure } \\
\text { downstream PV-4005? }\end{array}$ & $\begin{array}{l}\text { Fail open PV4005 or open } \\
\text { bypass results in } 100 \text { psig } \\
\text { pressure (PCV-4007) } \\
\text { downstream. }\end{array}$ & Likely & High pressure at WTM-152. & $\begin{array}{l}\text { PSV-5001 set at 10psi. Vent } \\
\text { system flow path design ( } 1 / 2 \text { or } \\
\text { greater SS Tubing). }\end{array}$ & & \\
\hline $\begin{array}{l}\text { H.4- } \\
25\end{array}$ & $\begin{array}{l}\text { What if V-153 is } \\
\text { blocked? }\end{array}$ & $\begin{array}{l}\text { Failure to drain V-153 } \\
\text { results in high liquid level. }\end{array}$ & Likely & $\begin{array}{l}\text { Process upset. Liquid to the } \\
\text { WTM152. }\end{array}$ & $\begin{array}{l}\text { Sight Glass SG-153 normally } \\
\text { empty. Drain valve HV-5001 } \\
\text { manually opened to remove the } \\
\text { liquid in V-153. }\end{array}$ & & \\
\hline $\begin{array}{l}\text { H.4- } \\
26\end{array}$ & $\begin{array}{l}\text { What if there is a leak } \\
\text { in the low pressure } \\
\text { vent system? }\end{array}$ & $\begin{array}{l}\text { Failure at a connection or } \\
\text { the WTM seal results in } \\
\text { release of hydrogen or } \\
\text { flammable vapor to } \\
\text { enclosure. }\end{array}$ & Likely & $\begin{array}{l}\text { Flammable atmosphere. } \\
\text { Potential creation of } \\
\text { flammable atmosphere. }\end{array}$ & $\begin{array}{l}\text { Design of vent system. } \\
\text { Procedural step calibration of } \\
\text { WTM. } \\
\text { Enclosure Design - Class } 1 \text { Div } 2 \\
\text { Enclosure Ventilation System. } \\
\text { Hydrogen monitors on skid and } \\
\text { in enclosure. } \\
\text { Flammable vapor monitor on } \\
\text { skid. } \\
\text { Fire suppression system in } \\
\text { enclosure. } \\
\text { Containment pan on skid and by } \\
\text { the enclosure. }\end{array}$ & C & \\
\hline
\end{tabular}

\footnotetext{
${ }^{2}$ In particular, PI-4008 had a minimum burst pressure of $~ 2200$ psig; it has been replaced with a gage that has a minimum burst pressures in excess of 3000 psig.
} 


\section{Hydrotreater/Distillation Column Hazard Analysis Report}

Table 3-4. What-If Hazards Analysis Results

\begin{tabular}{|c|c|c|c|c|c|c|c|}
\hline \multicolumn{8}{|c|}{$\begin{array}{l}\text { Hydrotreater Process Step 4. Operation } \\
\text { 1) Monitor feed and product levels. 2) When product drums are at } 85 \text { to } 90 \% \text { full, switch to other product tanks. 3) Download water vessel to product container. 4) Download oil vessel to } \\
\text { product container or transfer to still skid feed tank. }\end{array}$} \\
\hline $\begin{array}{l}\text { Hazard ID/ } \\
\text { Process } \\
\text { Step }\end{array}$ & What if: & Hazardous Scenario & $\begin{array}{l}\text { Likeli- } \\
\text { hood }\end{array}$ & Consequences & $\begin{array}{l}\text { Hazard Controls } \\
\mathrm{C}=\text { Critical Control }\end{array}$ & & Comments \\
\hline $\begin{array}{l}\text { H.4- } \\
27\end{array}$ & $\begin{array}{l}\text { What if you don't } \\
\text { switch tanks when } \\
\text { they are full? }\end{array}$ & $\begin{array}{l}\text { Failure to switch from full } \\
\text { tank results in overfilling } \\
\text { tank with the potential to } \\
\text { backup to LG-147 or into } \\
\text { the product gas header line } \\
\text { and plug (V-153 or WTM- } \\
\text { 152). }\end{array}$ & Likely & $\begin{array}{l}\text { Spray or Spill. Overfill of LG- } \\
147 \text { Could divert the liquid to } \\
\text { the gas system causing it to } \\
\text { plug also. } \\
\text { Partial blockage of flow and } \\
\text { pressurization of reactor. }\end{array}$ & $\begin{array}{l}\text { Level indication V-160A. } \\
\mathrm{H} / \mathrm{H} \text { alarm. Weight indication set } \\
\text { at } \mathrm{H}(12 \mathrm{~kg}) \text { and } \mathrm{H} / \mathrm{H} \text { interlock } \\
\text { (14kg) to ISCO pump. Trips LV- } \\
4003 \text { to close. }\end{array}$ & & \\
\hline $\begin{array}{l}\text { H.4- } \\
28\end{array}$ & $\begin{array}{l}\text { What if there is a leak } \\
\text { in product bio-oil } \\
\text { system downstream of } \\
\text { LG-147. }\end{array}$ & $\begin{array}{l}\text { Failure of connection or } \\
\text { open drain valve on V-160 } \\
\text { A/B results in release of } \\
\text { hydro-treated bio-oil to } \\
\text { containment and/or to } \\
\text { enclosure. } 19 \text { liters } \\
\text { maximum material spill } \\
\text { from completely full } \\
\text { vessel V-160A/B. }\end{array}$ & Unlikely & $\begin{array}{l}\text { Flammable atmosphere. } \\
\text { Spill of combustible liquid } \\
\text { (treated Bio-oil) and potential } \\
\text { creation of flammable } \\
\text { atmosphere. }\end{array}$ & $\begin{array}{l}\text { Pressure Test Procedure. } \\
\text { Design V-160A/B and piping. } \\
\text { Drains are double valved, valved } \\
\text { and capped, or valve and quick } \\
\text { disconnect. } \\
\text { Enclosure Design - Class } 1 \\
\text { Division } 2 \\
\text { Enclosure Ventilation System. } \\
\text { Flammable vapor monitor on } \\
\text { skid. } \\
\text { Fire suppression system in } \\
\text { enclosure. } \\
\text { Containment pan on skid and by } \\
\text { the enclosure. }\end{array}$ & $\begin{array}{l}\mathrm{C} \\
\mathrm{C}\end{array}$ & \\
\hline
\end{tabular}




\section{Hydrotreater/Distillation Column Hazard Analysis Report}

Table 3-4. What-If Hazards Analysis Results

\begin{tabular}{|c|c|c|c|c|c|c|c|}
\hline \multicolumn{8}{|c|}{$\begin{array}{l}\text { Hydrotreater Process Step 4. Operation } \\
\text { 1) Monitor feed and product levels. 2) When product drums are at } 85 \text { to } 90 \% \text { full, switch to other product tanks. 3) Download water vessel to product container. 4) Download oil vessel to } \\
\text { product container or transfer to still skid feed tank. }\end{array}$} \\
\hline $\begin{array}{l}\text { Hazard ID/ } \\
\text { Process } \\
\text { Step }\end{array}$ & What if: & Hazardous Scenario & $\begin{array}{l}\text { Likeli- } \\
\text { hood }\end{array}$ & Consequences & $\begin{array}{l}\text { Hazard Controls } \\
\text { C = Critical Control }\end{array}$ & & Comments \\
\hline $\begin{array}{l}\text { H.4- } \\
29\end{array}$ & $\begin{array}{l}\text { What if high pressure } \\
\text { V-160A/B? }\end{array}$ & $\begin{array}{l}\text { Failure in low pressure } \\
\text { nitrogen system results in } \\
\text { high pressure in V-160A/B } \\
\text { and failure of pressure } \\
\text { boundary release treated } \\
\text { bio-oil and nitrogen to } \\
\text { enclosure. }\end{array}$ & Likely & $\begin{array}{l}\text { Energetic event - failure of V- } \\
\text { 160A/B pressure boundary. } \\
\text { Spill/Spray of combustible } \\
\text { liquid (treated bio-oil) and } \\
\text { potential creation of } \\
\text { flammable atmosphere. } \\
\text { Creation of oxygen deficient } \\
\text { atmosphere. }\end{array}$ & $\begin{array}{l}\text { Design of V-160A/B } 155 \text { psi. } \\
\text { V-160A/B PRV set at } 70 \text { psi. } \\
\text { Pressure regulation of the low } \\
\text { pressure nitrogen supply to } 100 \\
\text { psi. } \\
\text { Pressure regulation of the low } \\
\text { pressure nitrogen system pressure } \\
\text { to } 10 \text { psi. } \\
\text { Enclosure Design - Class } 1 \\
\text { Division } 2 \\
\text { Enclosure Ventilation System. } \\
\text { Flammable vapor monitor on } \\
\text { skid. } \\
\text { Fire suppression system in } \\
\text { enclosure. } \\
\text { Containment pan on skid and by } \\
\text { the enclosure. }\end{array}$ & $\begin{array}{l}\mathrm{C} \\
\mathrm{C}\end{array}$ & \\
\hline $\begin{array}{l}\text { H.4- } \\
30\end{array}$ & $\begin{array}{l}\text { What if there is a } \\
\text { bypass of LG-147? }\end{array}$ & $\begin{array}{l}\text { Failure to close or } \\
\text { inadvertent opening of } \\
\text { HV-4022 results in } \\
\text { directing aqueous and } \\
\text { treated bio-oil into the tank } \\
\text { V-162. }\end{array}$ & Likely & Process Upset loss of product. & $\begin{array}{l}\text { Valve lineup procedure. Tank V- } \\
162 \text { is } 38 \text { liters. System designed } \\
\text { to } 180 \text { psi but open to } \\
\text { atmosphere. Weight of product } \\
\text { vessels would indicate lack of } \\
\text { filling. } \\
\text { Visual inspection (low level) of } \\
\text { LG-147. }\end{array}$ & & \\
\hline $\begin{array}{l}\text { H.4- } \\
31\end{array}$ & $\begin{array}{l}\text { What if there is a leak } \\
\text { in product water } \\
\text { system downstream of } \\
\text { LG-147? }\end{array}$ & $\begin{array}{l}\text { Failure of connection or } \\
\text { open drain valve on V- } \\
161 \mathrm{~A} / \mathrm{B} \text { results in release } \\
\text { of product water to } \\
\text { containment and/or to } \\
\text { enclosure. } 19 \text { liters } \\
\text { maximum material spill } \\
\text { from completely full } \\
\text { vessel V-161A/B. }\end{array}$ & Unlikely & $\begin{array}{l}\text { Spray or Spill. Spill of water } \\
\text { to containment and/or to } \\
\text { enclosure. }\end{array}$ & $\begin{array}{l}\text { Pressure Test Procedure. } \\
\text { Design V-161A/B and piping. } \\
\text { Drains are double valved, valved } \\
\text { and capped, or valve and quick } \\
\text { disconnect. } \\
\text { Containment pan on skid and by } \\
\text { the enclosure. }\end{array}$ & & $\begin{array}{l}\text { Spill of product is mostly } \\
\text { water. }\end{array}$ \\
\hline
\end{tabular}




\section{Hydrotreater/Distillation Column Hazard Analysis Report}

Table 3-4. What-If Hazards Analysis Results

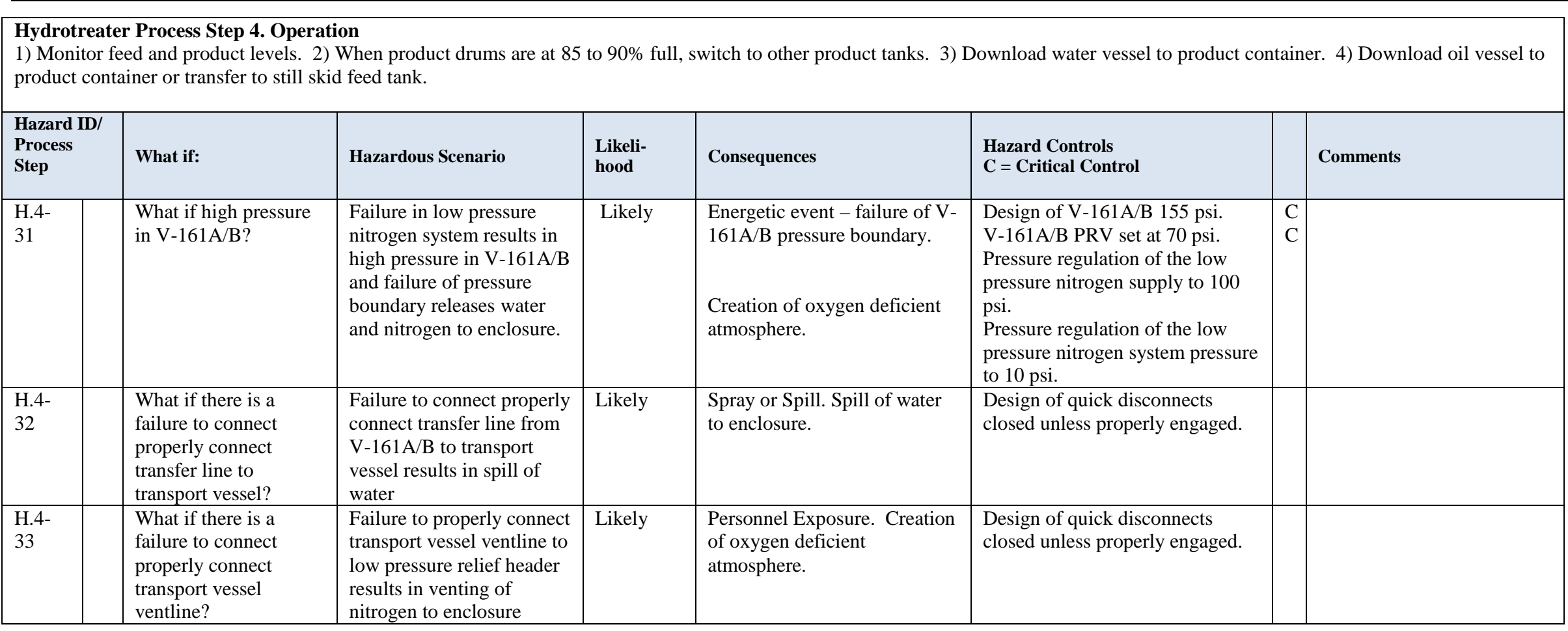




\section{Hydrotreater/Distillation Column Hazard Analysis Report}

Table 3-4. What-If Hazards Analysis Results

\begin{tabular}{|c|c|c|c|c|c|c|c|}
\hline \multicolumn{8}{|c|}{$\begin{array}{l}\text { Hydrotreater Process Step 5. Transfer to still feed tank } \\
\text { 1) Pad oil product container. 2) Depad still feed tank. 3) Connect transfer line. 4) Open transfer valves. 5) When empty, close transfer valves. 6) Pad still tank. 7) Depad product } \\
\text { container. 8) Remove transfer line. }\end{array}$} \\
\hline $\begin{array}{l}\text { Hazar } \\
\text { Proces } \\
\text { Step }\end{array}$ & What if: & Hazardous Scenario & $\begin{array}{l}\text { Likeli- } \\
\text { hood }\end{array}$ & Consequences & \multicolumn{2}{|l|}{$\begin{array}{l}\text { Hazard Controls } \\
\text { C = Critical Control }\end{array}$} & Comments \\
\hline $\begin{array}{l}\text { H.5- } \\
1\end{array}$ & $\begin{array}{l}\text { What if there is failure } \\
\text { to depad V-180? }\end{array}$ & $\begin{array}{l}\text { Operator fails to depad V- } \\
180 \text { prior to starting } \\
\text { transfer from V-160A/B } \\
\text { results in inability to } \\
\text { transfer due to high } \\
\text { pressure in V-180 (nominal } \\
\text { pressure is the same in both } \\
\text { systems). }\end{array}$ & Likely & $\begin{array}{l}\text { Process upset. No transfer. } \\
\text { Nominal pressure is the same in } \\
\text { both systems. }\end{array}$ & \multicolumn{2}{|l|}{$\begin{array}{l}\text { Weight indication on V-160A. } \\
\text { Level indicator on V-180. } \\
\text { High-High level alarm on V- } \\
\text { 160A. } \\
\text { Procedural step. }\end{array}$} & \\
\hline $\begin{array}{l}\text { H.5- } \\
2\end{array}$ & $\begin{array}{l}\text { What if there is failure } \\
\text { to properly connect the } \\
\text { transfer lines from } \\
160 \text { A to V-180? }\end{array}$ & $\begin{array}{l}\text { Failure to properly connect } \\
\text { transfer line to V-180 } \\
\text { results in spill or spray of } \\
\text { hydro-treated bio-oil to the } \\
\text { enclosure. }\end{array}$ & Likely & $\begin{array}{l}\text { Flammable atmosphere. } \\
\text { Spill/Spray of combustible } \\
\text { liquid (treated bio-oil) and } \\
\text { potential creation of flammable } \\
\text { atmosphere. }\end{array}$ & $\begin{array}{l}\text { Design of quick disconnects } \\
\text { (closed unless properly engaged). } \\
\text { Enclosure Design -Class } 1 \text { Div } 2 . \\
\text { Enclosure Ventilation. } \\
\text { Containment for both skids and } \\
\text { enclosure. } \\
\text { Flammable vapor monitoring on } \\
\text { hydrotreater skid. } \\
\text { Fire suppression system in } \\
\text { enclosure. }\end{array}$ & C & Bounds line failures. \\
\hline $\begin{array}{l}\text { H.5- } \\
3\end{array}$ & $\begin{array}{l}\text { What if there is failure } \\
\text { to close the transfer } \\
\text { valves and restore the } \\
\text { pad to V-180? }\end{array}$ & $\begin{array}{l}\text { Operator applies pad to V- } \\
180 \text { without closing the } \\
\text { three valves (HV-8017 \& } \\
\text { HV- } 6028 \text { \& HV 6016) } \\
\text { results in nitrogen flows } \\
\text { backflow until pressure } \\
\text { equalizes or release of } \\
\text { nitrogen enclosure via } \\
\text { disconnect on transfer line. }\end{array}$ & Likely & $\begin{array}{l}\text { Creation of oxygen deficient } \\
\text { atmosphere. }\end{array}$ & $\begin{array}{l}\text { Design of quick disconnects } \\
\text { (closed unless properly engaged). } \\
\text { Enclosure Design - Class } 1 \\
\text { Division 2. } \\
\text { Enclosure Ventilation. } \\
\text { Procedure. }\end{array}$ & & \\
\hline
\end{tabular}




\section{Hydrotreater/Distillation Column Hazard Analysis Report}

Table 3-4. What-If Hazards Analysis Results

\section{Hydrotreater Process Step 6. Shutdown}

1) Stop oil feed and turn off reactor heaters. 2) Continue product vessel monitoring per “operation” section. 3) Empty pumps back to bio-oil feed tank. 4) Reduce gas flow once product collection has diminished. 5) Allow reactor to cool.

\begin{tabular}{|c|c|c|c|c|c|c|c|c|}
\hline $\begin{array}{l}\text { Hazar } \\
\text { Proce } \\
\text { Step }\end{array}$ & & What if: & Hazardous Scenario & $\begin{array}{l}\text { Likeli- } \\
\text { hood }\end{array}$ & Consequences & $\begin{array}{l}\text { Hazard Controls } \\
\text { C = Critical Control }\end{array}$ & & Comments \\
\hline $\begin{array}{l}\text { H.6- } \\
1\end{array}$ & 3 & $\begin{array}{l}\text { What if there is failure } \\
\text { to isolate the reactor } \\
\text { from the feed pumps? }\end{array}$ & $\begin{array}{l}\text { Operator opens HV2009 } \\
\text { without closing HV2006 } \\
\text { resulting in backflow of } \\
\text { steam/hydrogen, } \\
\text { flammable vapors, bio-oil } \\
\text { into enclosure. }\end{array}$ & Likely & $\begin{array}{l}\text { Flammable atmosphere. } \\
\text { Release of steam, hydrogen, } \\
\text { flammable gas, bio-oil into } \\
\text { enclosure with personnel in the } \\
\text { area. }\end{array}$ & $\begin{array}{l}\text { HV-2018 Action: Replace T } \\
\text { upstream HV-2009 with 3-way } \\
\text { Valve. } \\
\text { Check Valve (CK-2007) } \\
\text { Procedural step. }\end{array}$ & $\mathrm{C}$ & \\
\hline
\end{tabular}

\section{Hydrotreater Process Step 7. Flush}


down feed system and allow reactor to cool below 100C. 6) Halt gas flow and depressurize reactor. 7) Flush with Nitrogen. 8) Verify that all systems are off.

\begin{tabular}{|c|c|c|c|c|c|c|c|}
\hline $\begin{array}{l}\text { Hazard } \\
\text { ID/ } \\
\text { Process } \\
\text { Step }\end{array}$ & What if: & Hazardous Scenario & $\begin{array}{l}\text { Likeli- } \\
\text { hood }\end{array}$ & Consequences & $\begin{array}{l}\text { Hazard Controls } \\
\text { C = Critical Control }\end{array}$ & & Comments \\
\hline $\begin{array}{l}\text { H.7- } \\
1\end{array}$ & $\begin{array}{l}\text { What if the reactor is } \\
\text { greater than desired } \\
\text { temperature? }\end{array}$ & $\begin{array}{l}\text { Operator initiates flush prior } \\
\text { to cooling below desired } \\
\text { temperature results in } \\
\text { failure to adequately clean } \\
\text { catalyst/reactor. }\end{array}$ & Likely & $\begin{array}{l}\text { Process upset, inefficient } \\
\text { cleaning } \\
\text { Energetic Event. } \\
\text { Potential plug of reactor and } \\
\text { energetic failure due to } \\
\text { overpressure (continued } \\
\text { pumping of acetone). }\end{array}$ & $\begin{array}{l}\text { Procedural step } \\
\text { Design of R-130 pressure is } 3000 \\
\text { psi MAWP. } \\
\text { R-130 PRV set at } 3000 \text { psi. } \\
\text { High-High pressure interlock at } \\
2700 \text { psi. } \\
\text { ISCO Pump high pressure set } \\
\text { point (process controlled). } \\
\text { ISCO Pump firmware maximum } \\
\text { pressure of } 3750 \text { psi. } \\
\text { ISCO Pump shear pin at } 4500 \text { psi } \\
\text { Process control alarms for high } \\
\text { pressure. }\end{array}$ & $\begin{array}{l}\mathrm{C} \\
\mathrm{C}\end{array}$ & \\
\hline $\begin{array}{l}\text { H.7- } \\
2\end{array}$ & $\begin{array}{l}\text { What if we don't align } \\
\text { product valves to slop } \\
\text { tank? }\end{array}$ & $\begin{array}{l}\text { Failure to properly align } \\
\text { valves results in } \\
\text { misdirection of acetone } \\
\text { solutions to the product tank } \\
\text { instead of slop tank. }\end{array}$ & Likely & $\begin{array}{l}\text { Process upset. Loss of product } \\
\text { due to mixing of acetone } \\
\text { solution with product. }\end{array}$ & Procedural step & & \\
\hline
\end{tabular}




\section{Hydrotreater/Distillation Column Hazard Analysis Report}

Table 3-4. What-If Hazards Analysis Results

\begin{tabular}{|c|c|c|c|c|c|c|c|}
\hline \multicolumn{8}{|c|}{$\begin{array}{l}\text { Hydrotreater Process Step 7. Flush } \\
\text { 1) Reactor should be around 150C or lower for this procedure. 2) Load acetone into pumps via transfer tank. 3) Direct product valves to slop tank. 4) Inject acetone into reactor. 5) Shut } \\
\text { down feed system and allow reactor to cool below 100C. 6) Halt gas flow and depressurize reactor. 7) Flush with Nitrogen. 8) Verify that all systems are off. }\end{array}$} \\
\hline $\begin{array}{l}\text { Hazard } \\
\text { ID/ } \\
\text { Process } \\
\text { Step }\end{array}$ & What if: & Hazardous Scenario & $\begin{array}{l}\text { Likeli- } \\
\text { hood }\end{array}$ & Consequences & $\begin{array}{l}\text { Hazard Controls } \\
\text { C = Critical Control }\end{array}$ & & Comments \\
\hline $\begin{array}{l}\text { H.7- } \\
3\end{array}$ & $\begin{array}{l}\text { What if other than } \\
\text { acetone in V-125? }\end{array}$ & $\begin{array}{l}\text { Operator error results in } \\
\text { filling V-125 with sulfiding } \\
\text { solution instead of acetone. }\end{array}$ & Likely & $\begin{array}{l}\text { Process upset. Coke the catalyst } \\
\text { and potentially evolve higher } \\
\text { than expected H2S. }\end{array}$ & $\begin{array}{l}\text { H2S monitor on vent stack. } \\
\text { Procedural step. }\end{array}$ & & \\
\hline $\begin{array}{l}\text { H.7- } \\
4\end{array}$ & $\begin{array}{l}\text { What if too much } \\
\text { pressure to } \mathrm{V}-125 \\
\text { from nitrogen pad? }\end{array}$ & $\begin{array}{l}\text { Failure to correctly set (or } \\
\text { failure of pressure control } \\
\text { valve) low pressure nitrogen } \\
\text { pressure results in } \\
\text { overpressurize V-125 with } \\
>10 \text { psi up to } 100 \text { psi of } \\
\text { nitrogen resulting in failure } \\
\text { of pressure boundary and } \\
\text { release of acetone /nitrogen } \\
\text { to enclosure. }\end{array}$ & Likely & $\begin{array}{l}\text { Energetic event - failure of V- } \\
125 \text { pressure boundary. } \\
\text { Flammable atmosphere. } \\
\text { Spill of flammable liquid and } \\
\text { potential creation of flammable } \\
\text { atmosphere with personnel } \\
\text { present. } \\
\text { Creation of an oxygen deficient } \\
\text { environment. }\end{array}$ & $\begin{array}{l}\text { Pressure limit on the low pressure } \\
\text { system. } \\
\text { Pressure set point, pressure } \\
\text { control for system, } \\
\text { Design of V-125 } 155 \text { psi MAWP } \\
\text { V-125 PRV set at } 100 \\
\text { Enclosure Design -Class } 1 \text { Div } 2 . \\
\text { Enclosure Ventilation System. } \\
\text { Flammable vapor monitoring on } \\
\text { skid. } \\
\text { Fire suppression system in } \\
\text { enclosure. }\end{array}$ & $\begin{array}{l}\mathrm{C} \\
\mathrm{C}\end{array}$ & \\
\hline $\begin{array}{l}\text { H.7- } \\
5\end{array}$ & $\begin{array}{l}\text { What if there is failure } \\
\text { to connect vent line } \\
\text { V-125 to rupture disk? }\end{array}$ & $\begin{array}{l}\text { Failure to connect vent line } \\
\text { to header results in venting } \\
\text { of V-125 contents to } \\
\text { enclosure on system } \\
\text { overpressure/failure of } \\
\text { rupture disk and release of } \\
\text { acetone /nitrogen to } \\
\text { enclosure. }\end{array}$ & Likely & $\begin{array}{l}\text { Flammable atmosphere. } \\
\text { Spill of flammable liquid and } \\
\text { potential creation of flammable } \\
\text { atmosphere with personnel } \\
\text { present. } \\
\text { Creation of an oxygen deficient } \\
\text { environment. }\end{array}$ & $\begin{array}{l}\text { Procedural step. Connect the } \\
\text { vent line prior to the nitrogen and } \\
\text { outlet. } \\
\text { Flammable vapor monitoring on } \\
\text { skid. } \\
\text { Fire suppression system in } \\
\text { enclosure. } \\
\text { Enclosure Design -Class } 1 \text { Div } 2 . \\
\text { Enclosure Ventilation System } \\
\end{array}$ & $\begin{array}{l}\mathrm{C} \\
\mathrm{C} \\
\end{array}$ & \\
\hline $\begin{array}{l}\text { H.7- } \\
6\end{array}$ & $\begin{array}{l}\text { What if flow rate of } \\
\text { acetone is too high? }\end{array}$ & $\begin{array}{l}\text { Set pump flow rate too } \\
\text { high. }\end{array}$ & Likely & $\begin{array}{l}\text { Process upset. Potential to } \\
\text { overwhelm liquid to gas } \\
\text { separator V-140 resulting in } \\
\text { over flow to the product gas } \\
\text { system and out to the vent } \\
\text { system. }\end{array}$ & $\begin{array}{l}\text { Process monitoring. Same } \\
\text { controls as Plugging and } \\
\text { overfilling V-140. }\end{array}$ & & $\begin{array}{l}\text { Flow rate is limited by the } \\
\text { pump to } 400 \mathrm{ml} / \text { min. } \\
\text { which would only last } 2.5 \\
\text { minutes }\end{array}$ \\
\hline
\end{tabular}




\section{Hydrotreater/Distillation Column Hazard Analysis Report}

Table 3-4. What-If Hazards Analysis Results

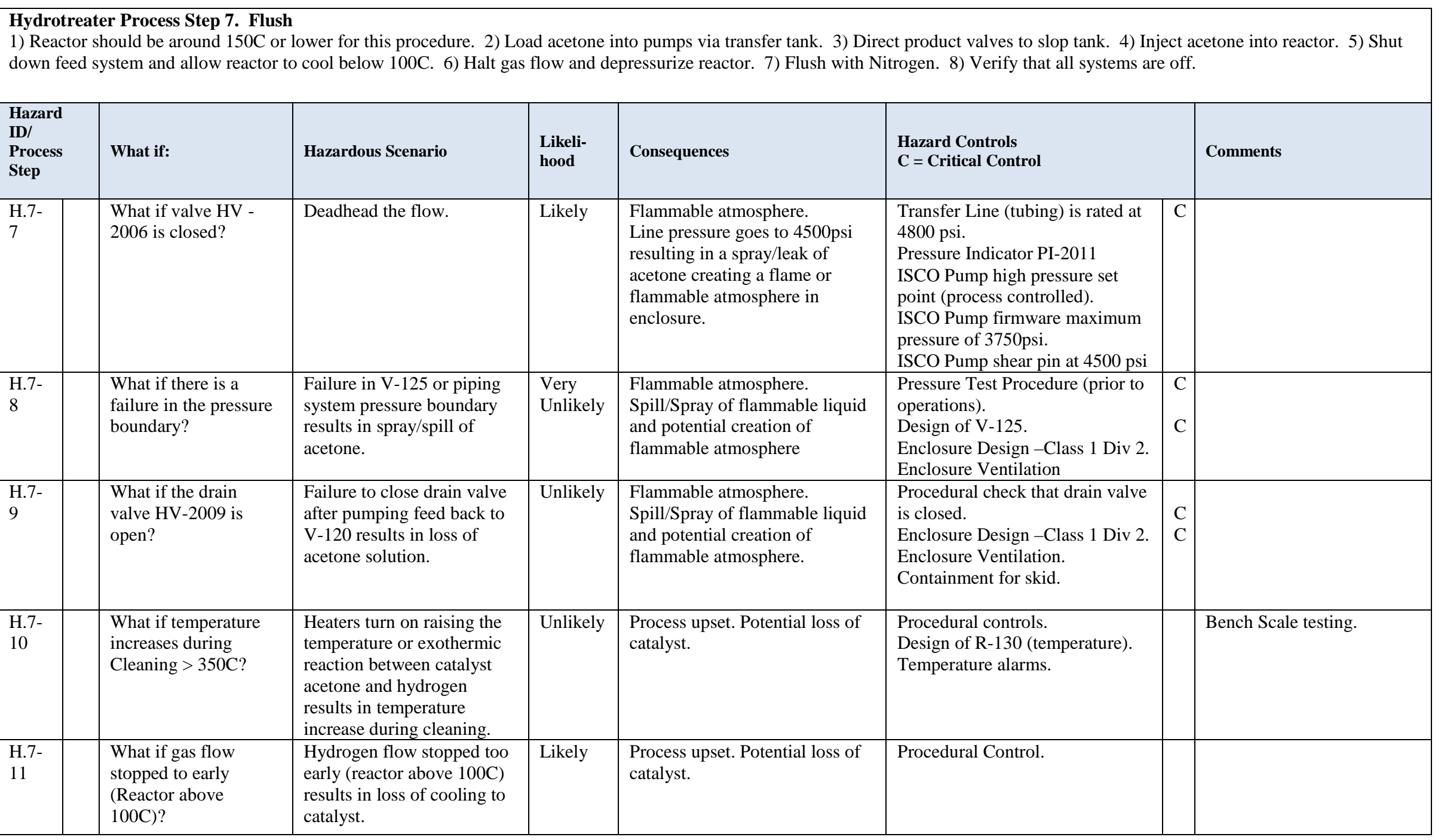

\section{Hydrotreater Process Step 8. Refit}

1) Depressurize and verify zero energy state on all hydrotreater subsystems. 2) Chain out inter-skid area prior to working on upper head. 3) Open upper reactor head

4) Remove catalyst. 
Hydrotreater/Distillation Column Hazard Analysis Report

Table 3-4. What-If Hazards Analysis Results

\begin{tabular}{|c|c|c|c|c|c|c|c|}
\hline $\begin{array}{l}\text { Hazard ID/ } \\
\text { Process } \\
\text { Step }\end{array}$ & What if: & Hazardous Scenario & $\begin{array}{l}\text { Likeli- } \\
\text { hood }\end{array}$ & Consequences & $\begin{array}{l}\text { Hazard Controls } \\
\text { C = Critical Control }\end{array}$ & & Comments \\
\hline $\begin{array}{l}\text { H.8- } \\
1\end{array}$ & $\begin{array}{l}\text { What if fail to } \\
\text { depressurize before } \\
\text { breaking into the } \\
\text { system? }\end{array}$ & $\begin{array}{l}\text { Operator fails to } \\
\text { depressurize reactor vessel } \\
\text { prior to breeching pressure } \\
\text { boundary resulting in } \\
\text { release of nitrogen. }\end{array}$ & Likely & $\begin{array}{l}\text { Personnel exposure. Release of } \\
\text { Nitrogen to the enclosure. } \\
\text { Potential personnel exposure to } \\
\text { high pressure nitrogen. }\end{array}$ & $\begin{array}{l}\text { Procedural. Pressure indicator on } \\
\text { reactor. } \\
\text { Enclosure Ventilation System. } \\
\text { Flammable vapor monitor and } \\
\text { hydrogen monitor on skid would } \\
\text { detect significant flammable } \\
\text { vapor /hydrogen release. }\end{array}$ & & \\
\hline $\begin{array}{l}\text { H.8- } \\
2\end{array}$ & $\begin{array}{l}\text { What if fail to purge } \\
\text { with nitrogen before } \\
\text { breaking into the } \\
\text { system? }\end{array}$ & $\begin{array}{l}\text { Operator fails to perform } \\
\text { nitrogen purge after } \\
\text { acetone flush resulting in } \\
\text { release of } \\
\text { hydrogen/acetone vapors } \\
\text { to the enclosure }\end{array}$ & Likely & $\begin{array}{l}\text { Flammable atmosphere. } \\
\text { Release of hydrogen gas - } \\
\text { Creation of flammable } \\
\text { environment with personnel } \\
\text { present. }\end{array}$ & $\begin{array}{l}\text { Procedural. } \\
\text { Enclosure Ventilation System. } \\
\text { Flammable vapor monitor on } \\
\text { skid. } \\
\text { Hydrogen monitor on skid and in } \\
\text { enclosure }\end{array}$ & & $\begin{array}{l}\text { Nitrogen flush peformed } \\
\text { prior to disassembly. } \\
\text { (possibly between step } 6 \\
\text { and } 7 \text { of flush) }\end{array}$ \\
\hline $\begin{array}{l}\text { H.8- } \\
3\end{array}$ & $\begin{array}{l}\text { What if fail to purge } \\
\text { and depressurize before } \\
\text { breaking into the } \\
\text { system? }\end{array}$ & $\begin{array}{l}\text { Operator fails to purge and } \\
\text { depressurize reactor vessel } \\
\text { prior to breeching pressure } \\
\text { boundary resulting in } \\
\text { release of high pressure } \\
\text { hydrogen/acetone vapors } \\
\text { to the enclosure }\end{array}$ & Unlikely & $\begin{array}{l}\text { Flammable atmosphere. } \\
\text { Spray of hydrogen gas - } \\
\text { Creation of flammable } \\
\text { environment with personnel } \\
\text { present. } \\
\text { Potential personnel exposure to } \\
\text { high pressure hydrogen and } \\
\text { acetone vapors. }\end{array}$ & $\begin{array}{l}\text { Pressure indicator on reactor. } \\
\text { Procedural. Verify zero energy- } \\
\text { procedural step and hold point. } \\
\text { This defines transition to non } \\
\text { Class I/Div } 2 \text {. } \\
\text { Enclosure Ventilation System. } \\
\text { Flammable vapor monitor on } \\
\text { skid. } \\
\text { Hydrogen monitor on skid and in } \\
\text { enclosure. }\end{array}$ & $\mathrm{C}$ & $\begin{array}{l}\text { Nitrogen flush peformed } \\
\text { prior to disassembly. } \\
\text { (possibly between step } 6 \\
\text { and } 7 \text { of flush) }\end{array}$ \\
\hline
\end{tabular}




\section{Hydrotreater/Distillation Column Hazard Analysis Report}

Table 3-4. What-If Hazards Analysis Results

\section{Distillation Process Step 1. Prestart Operations}

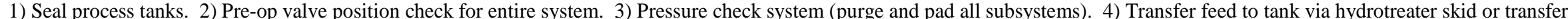
tank using tank pads. 5) Alternately, feed can be loaded into one of the bottoms product tanks and padded over. 6) Put valves to flow positions, including bottoms and distillate product tanks. 7) Prime feed pump and turn to auto control.

\begin{tabular}{|c|c|c|c|c|c|c|}
\hline $\begin{array}{l}\text { Hazard } \\
\text { ID/ } \\
\text { Process } \\
\text { Step }\end{array}$ & What if: & Hazardous Scenario & $\begin{array}{l}\text { Likeli- } \\
\text { hood }\end{array}$ & Consequences & $\begin{array}{l}\text { Hazard Controls } \\
\mathrm{C}=\text { Critical Control }\end{array}$ & Comments \\
\hline $\begin{array}{l}\text { D.1- } \\
1\end{array}$ & $\begin{array}{l}\text { What if you fail to } \\
\text { properly } \\
\text { reassemble seals / } \\
\text { flanges / piping } \\
\text { connections? }\end{array}$ & $\begin{array}{l}\text { Failure to re-assemble or failure } \\
\text { in seals/flanges/piping } \\
\text { connections results in loss of } \\
\text { pressure boundary integrity and } \\
\text { release of low pressure nitrogen } \\
\text { into enclosure. }\end{array}$ & Likely & $\begin{array}{l}\text { Creation of oxygen deficient } \\
\text { atmosphere with personnel } \\
\text { present. }\end{array}$ & $\begin{array}{l}\text { Pressure Test Procedure. } \\
\text { Enclosure Ventilation System } \\
\text { operable when system is } \\
\text { pressurized. } \\
\text { Design of pressure vessels and } \\
\text { components. } \\
\text { Pressure indication on the } \\
\text { distillation column. }\end{array}$ & \\
\hline $\begin{array}{l}\text { D.1- } \\
2\end{array}$ & $\begin{array}{l}\text { What if valve is } \\
\text { left open? }\end{array}$ & $\begin{array}{l}\text { Failure to close vent valve prior } \\
\text { to starting pressure check. }\end{array}$ & Likely & $\begin{array}{l}\text { Process Upset. Vent to vent } \\
\text { header }\end{array}$ & $\begin{array}{l}\text { Valve lineup procedure. } \\
\text { Pressure Test Procedure. } \\
\text { Pressure indication through- out } \\
\text { system. }\end{array}$ & \\
\hline $\begin{array}{l}\text { D.1- } \\
3\end{array}$ & $\begin{array}{l}\text { What if valve is } \\
\text { left open? } \\
\text { (see HV-8007/8, } \\
\text { etc.) }\end{array}$ & $\begin{array}{l}\text { Failure to close valve (drain } \\
\text { valve) resulting in nitrogen } \\
\text { released into enclosure. }\end{array}$ & $\begin{array}{l}\text { Very } \\
\text { Unlikely }\end{array}$ & $\begin{array}{l}\text { Personnel exposure. Creation of } \\
\text { oxygen deficient atmosphere } \\
\text { with personnel present. } \\
\text { Potential for small (residual } \\
\text { amounts) flammable liquid } \\
\text { accumulation. }\end{array}$ & $\begin{array}{l}\text { Valve lineup procedure. } \\
\text { Pressure Test Procedure. } \\
\text { Ventilation system operable when } \\
\text { system is pressurized. } \\
\text { Drains are double valved, valved } \\
\text { and capped, or valve and quick } \\
\text { disconnect. }\end{array}$ & \\
\hline $\begin{array}{l}\text { D.1- } \\
4\end{array}$ & $\begin{array}{l}\text { What if failed to } \\
\text { pressure check } \\
\text { part of system due } \\
\text { to valve } \\
\text { misalignment? }\end{array}$ & $\begin{array}{l}\text { Inadequate pressure check, } \\
\text { combined with pre-existing leak } \\
\text { results in leak at operating } \\
\text { temperature and pressure, } \\
\text { releases of treated bio-oil/ } \\
\text { intermediate product vapors/ } \\
\text { nitrogen into enclosure. }\end{array}$ & Unlikely & $\begin{array}{l}\text { Spray or Spill. Release of treated } \\
\text { bio-oil/ intermediate product } \\
\text { vapors/ nitrogen into enclosure. } \\
\text { (subsequent operation) }\end{array}$ & $\begin{array}{l}\text { Valve lineup procedures. } \\
\text { Pressure Test Procedure -pressure } \\
\text { indicators on individual tanks and } \\
\text { sub-systems. } \\
\text { Flammable vapor monitor on skid. } \\
\text { Enclosure Design - Class } 1 \\
\text { Division 2. } \\
\text { Enclosure Ventilation System. }\end{array}$ & \\
\hline $\begin{array}{l}\text { D.1- } \\
5\end{array}$ & $\begin{array}{l}\text { What if fail to do } \\
\text { the pressure test? }\end{array}$ & $\begin{array}{l}\text { Failure to perform pressure } \\
\text { check, combined with pre- } \\
\text { existing leak results in leak at } \\
\text { operating temperature and } \\
\text { pressure, releases of treated bio- } \\
\text { oil/ intermediate product vapors/ } \\
\text { nitrogen into enclosure. }\end{array}$ & Unlikely & $\begin{array}{l}\text { Spray or Spill. Release of } \\
\text { processed bio-oil intermediate } \\
\text { product vapors/ nitrogen into } \\
\text { enclosure. } \\
\text { (subsequent operation) }\end{array}$ & $\begin{array}{l}\text { Pressure Test Procedure.(detection } \\
\text { of no pressure) } \\
\text { Flammable vapor monitor on skid. } \\
\text { Enclosure Design - Class } 1 \\
\text { Division } 2 . \\
\text { Enclosure Ventilation System. }\end{array}$ & \\
\hline
\end{tabular}




\section{Hydrotreater/Distillation Column Hazard Analysis Report}

Table 3-4. What-If Hazards Analysis Results

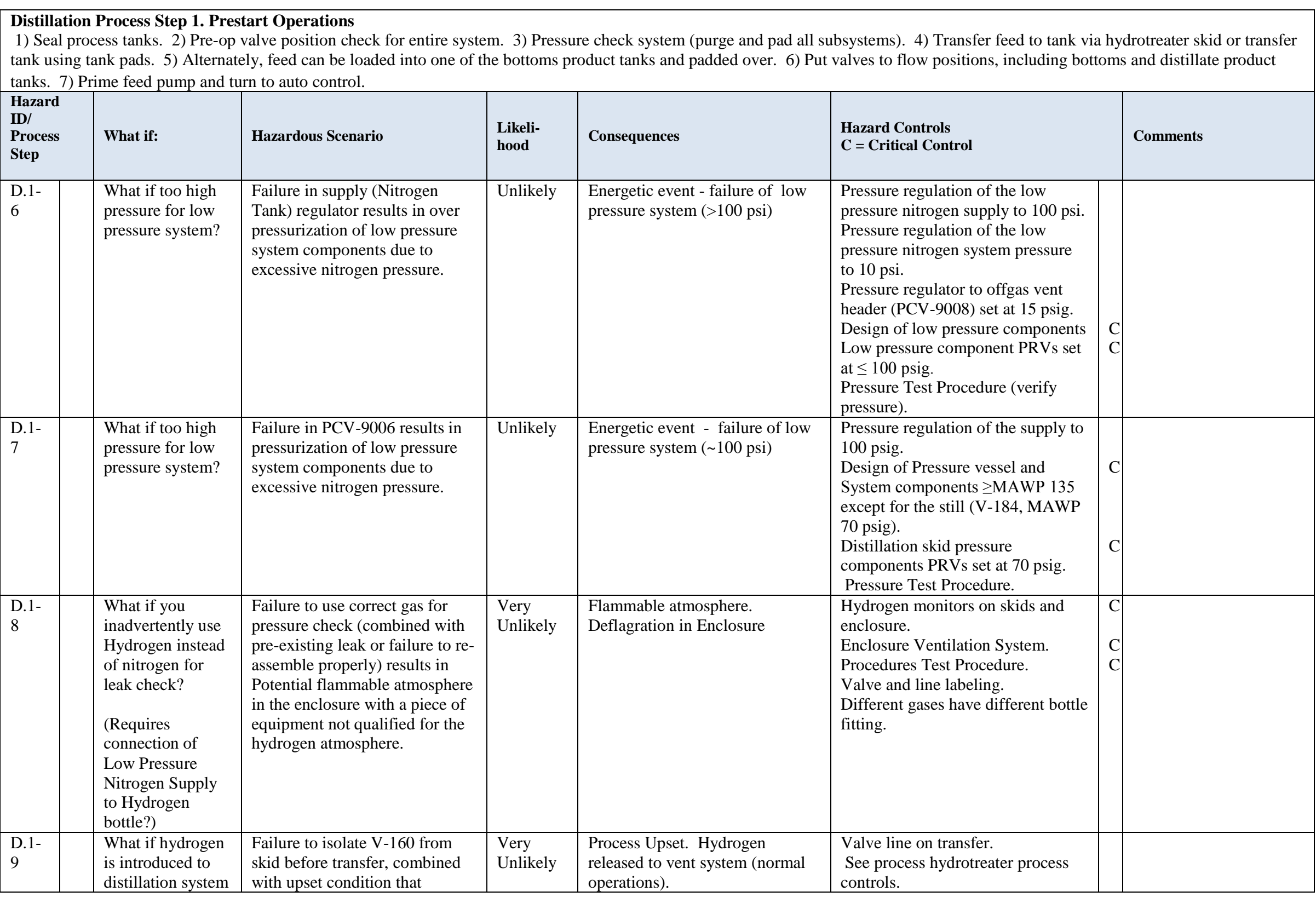




\section{Hydrotreater/Distillation Column Hazard Analysis Report}

Table 3-4. What-If Hazards Analysis Results

\begin{tabular}{|c|c|c|c|c|c|c|c|}
\hline $\begin{array}{l}\text { Distilla } \\
\text { 1) Seal } \\
\text { tank usi } \\
\text { tanks. }\end{array}$ & $\begin{array}{l}\text { Process Step 1. Pres } \\
\text { ress tanks. 2) Pre-op } \\
\text { ank pads. 5) Alternat } \\
\text { ime feed pump and to }\end{array}$ & $\begin{array}{l}\text { tart Operations } \\
\text { valve position check for entire sy } \\
\text { ly, feed can be loaded into one o } \\
\text { rn to auto control. }\end{array}$ & 3) $\operatorname{Pr}$ & $\begin{array}{l}\text { check system (purge and pad a } \\
\text { uct tanks and padded over. 6) }\end{array}$ & $\begin{array}{l}\text { systems). 4) Transfer feed to tan } \\
\text { alves to flow positions, including }\end{array}$ & $\begin{array}{l}\text { yc } \\
\text { as }\end{array}$ & $\begin{array}{l}\text { otreater skid or transfer } \\
\text { Ind distillate product }\end{array}$ \\
\hline \multirow[t]{2}{*}{$\begin{array}{l}\text { Hazard } \\
\text { ID/ } \\
\text { Process } \\
\text { Step }\end{array}$} & \multirow{2}{*}{$\begin{array}{l}\text { What if: } \\
\text { from } \\
\text { hydrotreater? }\end{array}$} & \multirow{2}{*}{$\begin{array}{l}\text { Hazardous Scenario } \\
\text { introduces process gas (requires } \\
\text { multiple conditions). }\end{array}$} & \multirow[t]{2}{*}{$\begin{array}{l}\text { Likeli- } \\
\text { hood }\end{array}$} & \multirow[t]{2}{*}{ Consequences } & \multicolumn{2}{|l|}{$\begin{array}{l}\text { Hazard Controls } \\
\text { C = Critical Control }\end{array}$} & \multirow[t]{2}{*}{ Comments } \\
\hline & & & & & & & \\
\hline $\begin{array}{l}\text { D.1- } \\
10\end{array}$ & $\begin{array}{l}\text { What if we } \\
\text { transfer product } \\
\text { too fast or at too } \\
\text { high of pressure? }\end{array}$ & $\begin{array}{l}\text { Transfer of product at greater } \\
\text { than expected pressure or flow } \\
\text { results in system breach and } \\
\text { release of treated bio-oil/ } \\
\text { intermediate products (recycle } \\
\text { from V-191-194) into enclosure }\end{array}$ & Unlikely & $\begin{array}{l}\text { Flammable atmosphere. } \\
\text { Spray or spill of flammable } \\
\text { liquid and vapors }\end{array}$ & $\begin{array}{l}\text { Pressure Limited to Low pressure } \\
\text { Nitrogen pressure. } \\
\text { V-180 rated at } 135 \text { psi MAWP. } \\
\text { Design } 1 / 2 \text { inch stainless steel } \\
\text { transfer line } \\
\text { V-180 PRV set at } 70 .\end{array}$ & $\begin{array}{l}\mathrm{C} \\
\mathrm{C} \\
\mathrm{C}\end{array}$ & $\begin{array}{l}\text { System designed for } \\
\text { maximum flow from } \\
\text { pump at maximum air } \\
\text { supply pressure. }\end{array}$ \\
\hline $\begin{array}{l}\text { D.1- } \\
11\end{array}$ & $\begin{array}{l}\text { What if we } \\
\text { transfer too much } \\
\text { bio-oil (over fill)? }\end{array}$ & $\begin{array}{l}\text { Failure to stop transfer results in } \\
\text { over fill of V-180. } \\
\text { Requires multiple transfers from } \\
\text { V-160A/B }\end{array}$ & Unlikely & $\begin{array}{l}\text { Spray or Spill. Overfill V-180 } \\
\text { resulting in release of bio-oil into } \\
\text { the vent system. }\end{array}$ & $\begin{array}{l}\text { Level indicator on V-180 and } \mathrm{H} / \mathrm{H} \\
\text { alarm. } \\
\mathrm{V}-180 \text { sized at } 140 \text { liters }\end{array}$ & & $\begin{array}{l}\text { Would require } 6 \text { or } 7 \\
\text { transfers. }\end{array}$ \\
\hline $\begin{array}{l}\text { D.1- } \\
12\end{array}$ & $\begin{array}{l}\text { What if there is a } \\
\text { leak in the bio-oil } \\
\text { line? }\end{array}$ & $\begin{array}{l}\text { Leak in transfer line from } \\
\text { Hydrotreater results in spill } \\
\text { /spray to enclosure. }\end{array}$ & Likely & $\begin{array}{l}\text { Spray or Spill. Release of treated } \\
\text { bio-oil into enclosure. }\end{array}$ & $\begin{array}{l}\text { Pressure boundary design. } \\
\text { Secondary containment provided } \\
\text { by enclosure. }\end{array}$ & & \\
\hline $\begin{array}{l}\text { D.1- } \\
13\end{array}$ & $\begin{array}{l}\text { What if air gets in } \\
\text { the system? }\end{array}$ & $\begin{array}{l}\text { Air in V-180 during manual } \\
\text { cleaning of vessel. }\end{array}$ & Likely & $\begin{array}{l}\text { Energetic event - Air in system } \\
\text { results in potential deflagration in } \\
\mathrm{V}-180 \text {, if not purged.) }\end{array}$ & $\begin{array}{l}\text { Pressure Test Procedure - with } \\
\text { nitrogen purge. } \\
\text { P-181 will not pump gas. }\end{array}$ & $\mathrm{C}$ & \\
\hline $\begin{array}{l}\text { D.1- } \\
14\end{array}$ & $\begin{array}{l}\text { What if we failed } \\
\text { to line up properly } \\
\text { for operations? } \\
\text { (can HV- } \\
9025 / \mathrm{HV}-9021 \\
\text { block flow?) }\end{array}$ & $\begin{array}{l}\text { Failure to correctly align system } \\
\text { for operations after pressure test } \\
\text { results in blocked flow within } \\
\text { the system distillation column. }\end{array}$ & Likely & $\begin{array}{l}\text { Deadhead within system. High } \\
\text { pressure in distillation column or } \\
\text { piping. }\end{array}$ & $\begin{array}{l}\text { Valve Lineup Procedure. } \\
\text { Multiple PRVs (PRV on vessels, } \\
\text { PRV on pump), } \\
\text { Multiple process control alarms on } \\
\text { high level, high pressure. }\end{array}$ & $\mathrm{C}$ & \\
\hline $\begin{array}{l}\text { D.1- } \\
15\end{array}$ & $\begin{array}{l}\text { What if we } \\
\text { inadvertently } \\
\text { open an already } \\
\text { closed valve? }\end{array}$ & $\begin{array}{l}\text { Inadvertent opening of } \\
\text { (drain/manual transfer) valve } \\
\text { results in venting to enclosure or } \\
\text { header }\end{array}$ & Unlikely & $\begin{array}{l}\text { Potential for nitrogen release into } \\
\text { enclosure or vent. }\end{array}$ & $\begin{array}{l}\text { Procedures in place. Majority is } \\
\text { double- valved or pathways to } \\
\text { enclosure are valved and capped. }\end{array}$ & & \\
\hline
\end{tabular}




\section{Hydrotreater/Distillation Column Hazard Analysis Report}

Table 3-4. What-If Hazards Analysis Results

\begin{tabular}{|c|c|c|c|c|c|c|c|c|}
\hline \multicolumn{9}{|c|}{$\begin{array}{l}\text { Distillation Process 2. Startup } \\
\text { 1) Clear area of all maintenance work and equipment not compatible with Class } 1 \text { Div } 2 \text { environment. 2) Initiate purge of electrical cabinets and furnace. 3) Turn on coolant to HX and } \\
\text { pump bottoms. 4) Turn on nitrogen purge to heatup setpoint and set system backpressure. 5) Engage feed pump and set backpressure loop. 6) Fill still bottom to submerge heater } \\
\text { elements via feed control badger and/or bypass. 7) Turn on still heater and external jacket heater 8) As liquid level drops in still, set feed badger to maintain liquid height in still }\end{array}$} \\
\hline \multicolumn{2}{|c|}{$\begin{array}{l}\text { Hazard ID/ } \\
\text { Process } \\
\text { Step }\end{array}$} & \multirow{2}{*}{$\begin{array}{l}\text { What if: } \\
\text { What if you leave } \\
\text { non-Class } 1 \text { Div } 2 \\
\text { equipment in } \\
\text { environment? }\end{array}$} & \multirow{2}{*}{$\begin{array}{l}\text { Hazardous Scenario } \\
\text { Potential for flammable } \\
\text { atmosphere to reach ignition } \\
\text { sources. }\end{array}$} & \multirow{2}{*}{$\begin{array}{l}\begin{array}{l}\text { Likeli- } \\
\text { hood }\end{array} \\
\text { Unlikely }\end{array}$} & \multirow{2}{*}{$\begin{array}{l}\text { Consequences } \\
\text { Flammable atmosphere. } \\
\text { Potential ignition of a flammable } \\
\text { vapor given leak sufficient to } \\
\text { result in a flammable } \\
\text { atmosphere. }\end{array}$} & \multicolumn{2}{|l|}{$\begin{array}{l}\text { Hazard Controls } \\
\mathrm{C}=\text { Critical Control }\end{array}$} & \multirow[t]{2}{*}{ Comments } \\
\hline D.2-1 & 1 & & & & & $\begin{array}{l}\text { Procedure steps. } \\
\text { Pressure Test Procedure. } \\
\text { Enclosure Ventilation System. } \\
\text { Alarms for flammable vapors on } \\
\text { skid. }\end{array}$ & $\begin{array}{l}C \\
C\end{array}$ & \\
\hline D.2-2 & 1 & $\begin{array}{l}\text { What if you bring in } \\
\text { non-Class } 1 \text { Div } 2 \\
\text { equipment into the } \\
\text { enclosure during } \\
\text { operations? }\end{array}$ & $\begin{array}{l}\text { Potential for flammable } \\
\text { atmosphere to reach ignition } \\
\text { sources. }\end{array}$ & Unlikely & $\begin{array}{l}\text { Flammable atmosphere. } \\
\text { Potential ignition of a flammable } \\
\text { vapor given leak sufficient to } \\
\text { result in a flammable } \\
\text { atmosphere. }\end{array}$ & $\begin{array}{l}\text { Procedure steps. } \\
\text { Pressure Test Procedure. } \\
\text { Enclosure Ventilation System. } \\
\text { Alarms for flammable vapors on } \\
\text { skid. } \\
\text { Limit access to trained operators. } \\
\text { Procedural steps in place during } \\
\text { operations. }\end{array}$ & $\begin{array}{l}C \\
C\end{array}$ & \\
\hline D.2-3 & 2 & $\begin{array}{l}\text { What if you fail to } \\
\text { initiate purge of } \\
\text { electrical? }\end{array}$ & $\begin{array}{l}\text { Potential for flammable } \\
\text { atmosphere to reach ignition } \\
\text { sources. }\end{array}$ & Unlikely & $\begin{array}{l}\text { Flammable atmosphere. } \\
\text { Potential ignition of a flammable } \\
\text { vapor given leak sufficient to } \\
\text { result in a flammable } \\
\text { atmosphere. }\end{array}$ & $\begin{array}{l}\text { Enclosure Design - Class } 1 \text { Div 2, } \\
\text { Pressure monitoring and alarm on } \\
\text { cabinets (Z-purge). } \\
\text { System design } \\
\text { Pressure Test Procedure. } \\
\text { Enclosure Ventilation System. } \\
\text { Flammable vapor monitor on skid. }\end{array}$ & $\begin{array}{l}C \\
C \\
C \\
C\end{array}$ & \\
\hline D.2-4 & 3 & $\begin{array}{l}\text { What if you fail to } \\
\text { start coolant flow? }\end{array}$ & Loss of cooling to HE-185. & Likely & $\begin{array}{l}\text { Spray or Spill. Vent lighter } \\
\text { components to vent header from } \\
\text { V-186. Potential to fill vent } \\
\text { header with liquid (which would } \\
\text { go to stack) and plug system, } \\
\text { leading to back pressure on the } \\
\text { distillation column. Steam in the } \\
\text { water jacket. }\end{array}$ & $\begin{array}{l}\text { Flow monitor, temperature alarm } \\
\text { on Chilled Water system. Manual } \\
\text { flow indicator FIC-8001 (would } \\
\text { not see at computer). PRVs, } \\
\text { pressure indication, pressure } \\
\text { alarms on distillation column. }\end{array}$ & & \\
\hline D.2-5 & & $\begin{array}{l}\text { What if you fail to } \\
\text { start coolant flow? }\end{array}$ & $\begin{array}{l}\text { Loss of tempered water to P- } \\
182 .\end{array}$ & Likely & $\begin{array}{l}\text { Spray or Spill Failure of pump } \\
\text { seals and leak of heavy } \\
\text { components to secondary } \\
\text { containment. }\end{array}$ & $\begin{array}{l}\text { Temperature, local flow indication } \\
\text { on tempered water. Secondary } \\
\text { containment. }\end{array}$ & & \\
\hline D.2-6 & & $\begin{array}{l}\text { What if P-182 is } \\
\text { over-cooled? }\end{array}$ & $\begin{array}{l}\text { Set temperature control on } \\
\text { tempered water too low. }\end{array}$ & Likely & $\begin{array}{l}\text { Process upset. Inability to pump } \\
\text { from bottom of column. } \\
\text { Increase level in distillation. } \\
\text { Potential failure of pump. }\end{array}$ & $\begin{array}{l}\text { Temperature and flow indication. } \\
\text { Pressure on the line from the } \\
\text { pump. Level indication on } \\
\text { columns and product tanks. }\end{array}$ & & \\
\hline
\end{tabular}

Page 51 of 98 


\section{Hydrotreater/Distillation Column Hazard Analysis Report}

Table 3-4. What-If Hazards Analysis Results

\begin{tabular}{|c|c|c|c|c|c|c|c|c|}
\hline $\begin{array}{l}\text { Distil } \\
\text { 1) Cle } \\
\text { pump } \\
\text { eleme }\end{array}$ & artior & $\begin{array}{l}\text { Process } 2 \text {. Startup } \\
\text { a of all maintenance } \\
\text { ms. 4) Turn on nitro } \\
\text { a feed control badge }\end{array}$ & $\begin{array}{l}\text { and equipment not compatil } \\
\text { orge to heatup setpoint and s } \\
\text { or bypass. 7) Turn on still h }\end{array}$ & and ext & $\begin{array}{l}\text { iv } 2 \text { environment. 2) Initiate pu } \\
\text { ssure. 5) Engage feed pump ar } \\
\text { jacket heater 8) As liquid leve }\end{array}$ & $\begin{array}{l}\text { to electrical cabinets and furnace. } \\
\text { backpressure loop. 6) Fill still bot } \\
\text { ps in still, set feed badger to mainta }\end{array}$ & & $\begin{array}{l}\text { on coolant to } \mathrm{HX} \text { and } \\
\text { submerge heater } \\
\text { uid height in still }\end{array}$ \\
\hline \multicolumn{2}{|c|}{$\begin{array}{l}\text { Hazard ID/ } \\
\text { Process } \\
\text { Step }\end{array}$} & \multirow[t]{2}{*}{ What if: } & \multirow[t]{2}{*}{ Hazardous Scenario } & \multirow[t]{2}{*}{$\begin{array}{l}\text { Likeli- } \\
\text { hood }\end{array}$} & \multirow[t]{2}{*}{ Consequences } & \multicolumn{2}{|l|}{$\begin{array}{l}\text { Hazard Controls } \\
\mathrm{C}=\text { Critical Control }\end{array}$} & \multirow[t]{2}{*}{ Comments } \\
\hline & & & & & & $\begin{array}{l}\text { Temperature indication on product } \\
\text { tanks. Temperature indication, } \\
\text { alarm, interlock to Chiller system } \\
\text { on L/L. }\end{array}$ & & \\
\hline D.2-7 & 4 & $\begin{array}{l}\text { What if too much } \\
\text { pressure to from } \\
\text { nitrogen purge? }\end{array}$ & $\begin{array}{l}\text { Overpressurize V-184/V-186 } \\
\text { with greater than } 100 \text { psi of } \\
\text { nitrogen and blocked vent } \\
\text { header. }\end{array}$ & Unlikely & $\begin{array}{l}\text { Energetic event - failure of V- } \\
\text { 184/V-186 pressure boundary. }\end{array}$ & $\begin{array}{l}\text { Pressure limit on the low pressure } \\
\text { system. } \\
\text { Pressure set point, pressure control } \\
\text { for system. } \\
\text { Design of V-184/V-186. } \\
\text { PRV on V-184 set at } 70 \text { psi. } \\
\text { Pressure indication on vent header. }\end{array}$ & $\begin{array}{l}\mathrm{C} \\
\mathrm{C}\end{array}$ & \\
\hline D.2-8 & 4 & $\begin{array}{l}\text { What if too little } \\
\text { pressure to from } \\
\text { nitrogen purge? }\end{array}$ & $\begin{array}{l}\text { Failure op open/close HV- } \\
\text { 8008. Run out of nitrogen. }\end{array}$ & Likely & $\begin{array}{l}\text { Process upset. Incomplete } \\
\text { purge. }\end{array}$ & $\begin{array}{l}\text { Procedural steps. Local flow } \\
\text { indication. }\end{array}$ & & $\begin{array}{l}\text { May be a desired normal } \\
\text { operational scenario }\end{array}$ \\
\hline D.2-9 & 4 & $\begin{array}{l}\text { What if there is a } \\
\text { failure in the } \\
\text { pressure boundary } \\
\text { (nitrogen)? }\end{array}$ & Failure in nitrogen line. & Unlikely & $\begin{array}{l}\text { Personnel Exposure. Nitrogen } \\
\text { release to enclosure. Potential } \\
\text { backflow of flammable vapors } \\
\text { from system. Loss of ability to } \\
\text { transfer. } \\
\text { Possible process upset. } \\
\text { Incomplete purge. }\end{array}$ & $\begin{array}{l}\text { LP Nitrogen piping inside } \\
\text { Enclosure is Stainless Steel, ASME } \\
\text { B-31.3. Flammable vapor } \\
\text { detection on skid. Enclosure } \\
\text { ventilation. }\end{array}$ & & \\
\hline $\begin{array}{l}\text { D.2- } \\
10\end{array}$ & 5 & $\begin{array}{l}\text { What if back } \\
\text { pressure too high? }\end{array}$ & $\begin{array}{l}\text { Set back pressure within } \\
\text { distillation column too high } \\
\text { (e.g., max of } V-182 \text { ). }\end{array}$ & Likely & $\begin{array}{l}\text { Process upset. Eventual increase } \\
\text { of temperatures in top of } \\
\text { distillation column. }\end{array}$ & $\begin{array}{l}\text { Pressure and temperature } \\
\text { indication in distillation column. } \\
\text { H/H pressure alarm on column. } \\
\text { Temperature alarm. }\end{array}$ & & \\
\hline $\begin{array}{l}\text { D.2- } \\
11\end{array}$ & 5 & $\begin{array}{l}\text { What if back } \\
\text { pressure too low? }\end{array}$ & See "no nitrogen flow". & & & & & \\
\hline $\begin{array}{l}\text { D.2- } \\
12\end{array}$ & 6 & $\begin{array}{l}\text { What if fill distill } \\
\text { too high? }\end{array}$ & Failure to stop pumping. & Likely & $\begin{array}{l}\text { Process upset. Overfill to } \\
\text { distillate product tanks. } \\
\text { Overflow to vent header. }\end{array}$ & $\begin{array}{l}\text { Level indication and alarm on V- } \\
\text { 184, V-186. Visual indication in V- } \\
\text { 186. Pressure indicator PI-8023. }\end{array}$ & & \\
\hline $\begin{array}{l}\text { D.2- } \\
13\end{array}$ & 6 & $\begin{array}{l}\text { What if fill distill } \\
\text { too low? }\end{array}$ & Failure to submerge heaters. & Likely & $\begin{array}{l}\text { Process upset. Damage heater } \\
\text { elements with excessive heat. }\end{array}$ & $\begin{array}{l}\text { Temperature indication on heater } \\
\text { JE-N-8028. H/H trips to zero \% } \\
\text { output on heater element. Safety } \\
\text { H/H trips power to heater. } \\
\text { Level indication in column. }\end{array}$ & & \\
\hline
\end{tabular}




\section{Hydrotreater/Distillation Column Hazard Analysis Report}

Table 3-4. What-If Hazards Analysis Results

\begin{tabular}{|c|c|c|c|c|c|c|c|c|}
\hline \multicolumn{9}{|c|}{$\begin{array}{l}\text { Distillation Process 2. Startup } \\
\text { 1) Clear area of all maintenance work and equipment not compatible with Class } 1 \text { Div } 2 \text { environment. 2) Initiate purge of electrical cabinets and furnace. 3) Turn on coolant to HX and } \\
\text { pump bottoms. 4) Turn on nitrogen purge to heatup setpoint and set system backpressure. 5) Engage feed pump and set backpressure loop. 6) Fill still bottom to submerge heater } \\
\text { elements via feed control badger and/or bypass. 7) Turn on still heater and external jacket heater 8) As liquid level drops in still, set feed badger to maintain liquid height in still }\end{array}$} \\
\hline \multicolumn{2}{|c|}{$\begin{array}{l}\text { Hazard ID/ } \\
\text { Process } \\
\text { Step }\end{array}$} & \multirow{2}{*}{$\begin{array}{l}\text { What if: } \\
\text { What if no still } \\
\text { heater? }\end{array}$} & \multirow{2}{*}{$\begin{array}{l}\text { Hazardous Scenario } \\
\text { Failure to turn on still heater. }\end{array}$} & \multirow{2}{*}{$\begin{array}{l}\begin{array}{l}\text { Likeli- } \\
\text { hood }\end{array} \\
\text { Likely }\end{array}$} & \multirow{2}{*}{$\begin{array}{l}\text { Consequences } \\
\text { Process upset. No heat-up. }\end{array}$} & \multicolumn{2}{|l|}{$\begin{array}{l}\text { Hazard Controls } \\
\mathrm{C}=\text { Critical Control }\end{array}$} & Comments \\
\hline $\begin{array}{l}\text { D.2- } \\
14\end{array}$ & & & & & & $\begin{array}{l}\text { Temperature indication on column } \\
\text { and still. }\end{array}$ & & \\
\hline $\begin{array}{l}\text { D.2- } \\
15 \\
\end{array}$ & & $\begin{array}{l}\text { What if no jacket } \\
\text { heater? }\end{array}$ & Failure to turn on jacket heater. & Likely & $\begin{array}{l}\text { Process upset. Longer than } \\
\text { expected heat-up rate. }\end{array}$ & $\begin{array}{l}\text { Temperature indication on column } \\
\text { and still. }\end{array}$ & & \\
\hline $\begin{array}{l}\text { D.2- } \\
16\end{array}$ & & $\begin{array}{l}\text { What if still heater } \\
\text { too high? }\end{array}$ & Loss of still heater control. & Likely & $\begin{array}{l}\text { Process upset. Faster than } \\
\text { expected boil-off of product. } \\
\text { Potential uncovering of heater } \\
\text { and damage to heater (see } \\
\text { above). Process upset. }\end{array}$ & $\begin{array}{l}\text { Thermocouple on still heater. } \\
\text { Level indication in column. Output } \\
\text { flow indication. }\end{array}$ & & \\
\hline $\begin{array}{l}\text { D.2- } \\
17\end{array}$ & & $\begin{array}{l}\text { What if jacket } \\
\text { heater too high? }\end{array}$ & $\begin{array}{l}\text { Loss of jacket heater control } \\
\text { results in over-heating. }\end{array}$ & Likely & $\begin{array}{l}\text { Energetic Event. Potential } \\
\text { failure of pressure boundary due } \\
\text { to excessive temperature. } \\
\text { Faster than expected boil-off of } \\
\text { product (see above). }\end{array}$ & $\begin{array}{l}\text { Temperature indication on heater } \\
\text { JE-N-8023. } \\
\text { High-High Temperature on V-184. }\end{array}$ & $\mathrm{C}$ & \\
\hline $\begin{array}{l}\text { D.2- } \\
18\end{array}$ & 8 & $\begin{array}{l}\text { What if feed rate is } \\
\text { too high? }\end{array}$ & Feed rate set too high. & Likely & $\begin{array}{l}\text { Process upset. Potential eventual } \\
\text { overfill into vent system. }\end{array}$ & $\begin{array}{l}\text { Procedural step on start-up of } \\
\text { reflux. Level indication and alarm } \\
\text { on V-184, V-186. } \\
\text { Visual indication in V-186. } \\
\text { Pressure indicator PI-8023High- } \\
\text { High provides alarm and shuts off } \\
\text { pump. }\end{array}$ & & \\
\hline $\begin{array}{l}\text { D.2- } \\
19 \\
\end{array}$ & 8 & $\begin{array}{l}\text { What if feed rate is } \\
\text { too low? }\end{array}$ & Feed rate set too & Likely & See loss of still heater control. & & & \\
\hline
\end{tabular}

\section{Distillation Process Step 3. Reflux}

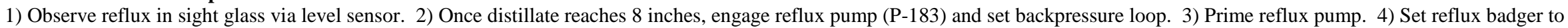
target kg/hr. 5) Set product badger to target liquid level in sight glass. 6) Reduce nitrogen flow to target setpoint and adjust system backpressure.

\begin{tabular}{|c|c|c|c|c|c|c|c|}
\hline \multicolumn{2}{|l|}{$\begin{array}{l}\text { Hazard } \\
\text { ID/ } \\
\text { Process } \\
\text { Step }\end{array}$} & What if: & Hazardous Scenario & $\begin{array}{l}\text { Likeli- } \\
\text { hood }\end{array}$ & Consequences & $\begin{array}{l}\text { Hazard Controls } \\
\mathrm{C}=\text { Critical Control }\end{array}$ & Comments \\
\hline D.3-1 & 1 & $\begin{array}{l}\text { What if reflux level too } \\
\text { high? }\end{array}$ & $\begin{array}{l}\text { Failure to start reflux } \\
\text { pump. }\end{array}$ & Likely & $\begin{array}{l}\text { Process upset. Overfill to } \\
\text { distillate product tanks. }\end{array}$ & $\begin{array}{l}\text { Procedural step. Level indication and } \\
\text { alarm on V-186. Visual indication in }\end{array}$ & \\
\hline
\end{tabular}




\section{Hydrotreater/Distillation Column Hazard Analysis Report}

Table 3-4. What-If Hazards Analysis Results

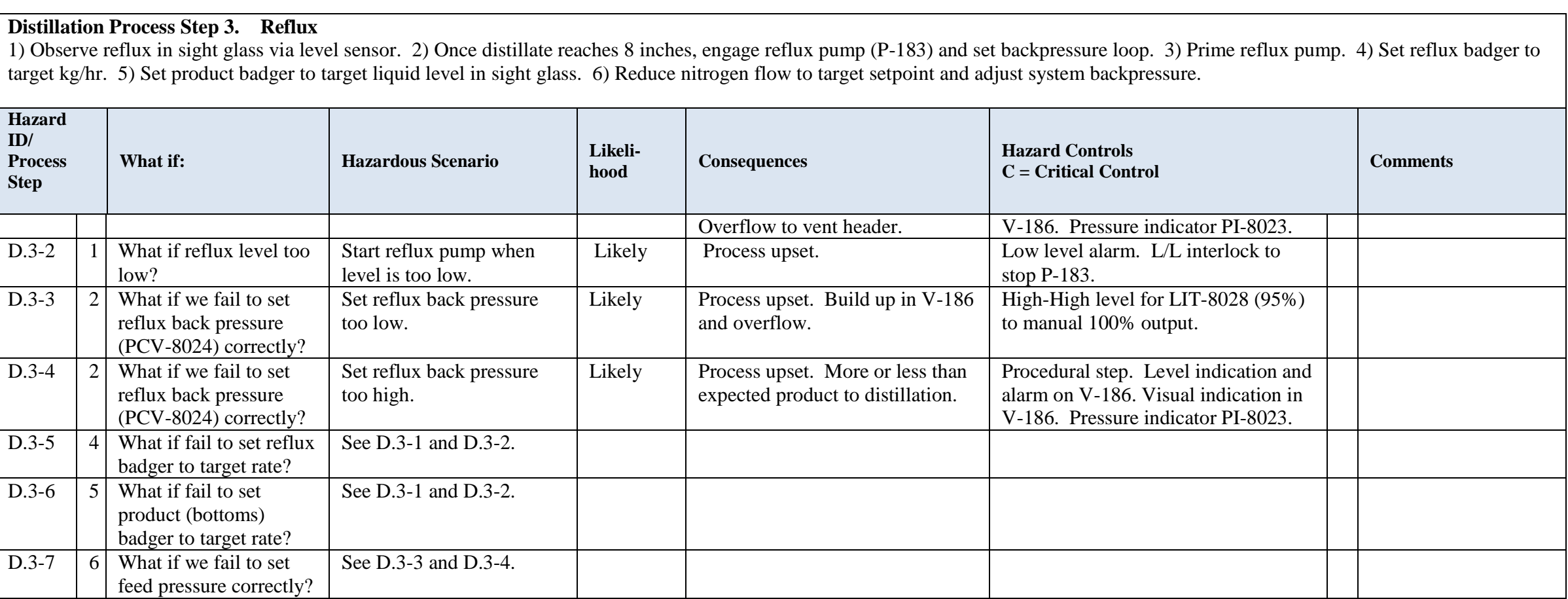

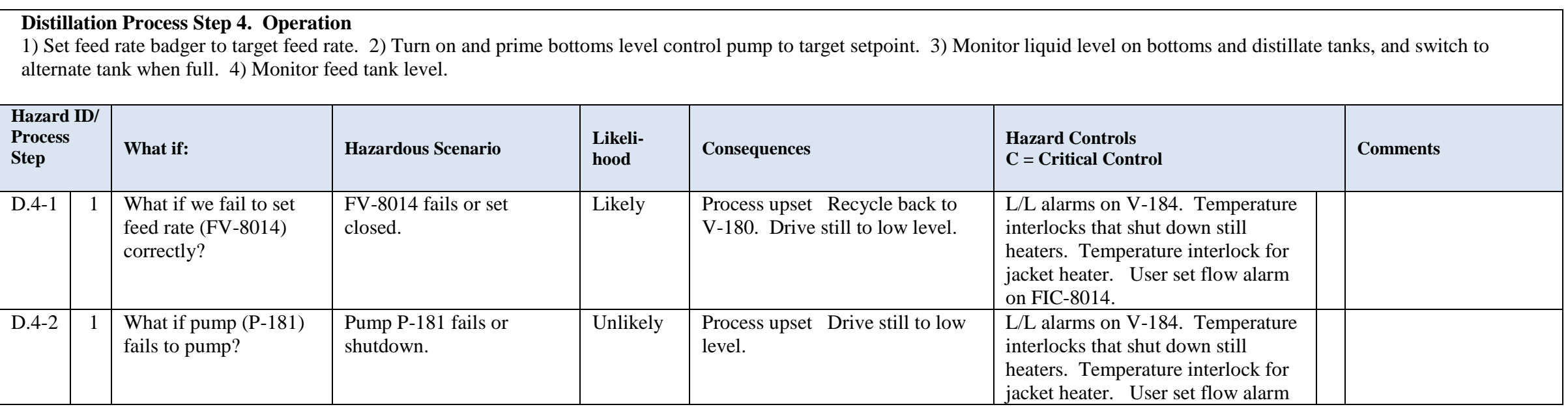

Page 54 of 98 


\section{Hydrotreater/Distillation Column Hazard Analysis Report}

Table 3-4. What-If Hazards Analysis Results

\begin{tabular}{|c|c|c|c|c|c|c|c|c|}
\hline \multicolumn{9}{|c|}{$\begin{array}{l}\text { Distillation Process Step 4. Operation } \\
\text { 1) Set feed rate badger to target feed rate. 2) Turn on and prime bottoms level control pump to target setpoint. 3) Monitor liquid level on bottoms and distillate tanks, and switch to } \\
\text { alternate tank when full. 4) Monitor feed tank level. }\end{array}$} \\
\hline \multicolumn{2}{|c|}{$\begin{array}{l}\text { Hazard ID/ } \\
\text { Process } \\
\text { Step }\end{array}$} & \multirow[t]{2}{*}{ What if: } & \multirow[t]{2}{*}{ Hazardous Scenario } & \multirow[t]{2}{*}{$\begin{array}{l}\text { Likeli- } \\
\text { hood }\end{array}$} & \multirow[t]{2}{*}{ Consequences } & \multicolumn{2}{|l|}{$\begin{array}{l}\text { Hazard Controls } \\
\text { C = Critical Control }\end{array}$} & \multirow[t]{2}{*}{ Comments } \\
\hline & & & & & & $\begin{array}{l}\text { on FIC-8014 pump indication if loss } \\
\text { of electrical power to the pump. }\end{array}$ & & \\
\hline D.4-3 & 1 & $\begin{array}{l}\text { What if we have } \\
\text { excessive pressure in } \\
\text { the Distillation } \\
\text { Column? }\end{array}$ & $\begin{array}{l}\text { There is a plug in the } \\
\text { system and we continue to } \\
\text { pump (normal operation), } \\
\text { challenging the pressure } \\
\text { boundary of the system. }\end{array}$ & Likely & Energetic event - failure of V-184 & $\begin{array}{l}\text { V-184 Design pressure } \\
\text { V-184 PRV set at } 70 \text { psi. } \\
\text { Pressure relief and control on pump. } \\
\text { Pump high pressure set point. }\end{array}$ & $\begin{array}{l}\mathrm{C} \\
\mathrm{C}\end{array}$ & $\begin{array}{l}\text { Bottoms pump P-182 } \\
\text { would try to maintain } \\
\text { level in V-184 }\end{array}$ \\
\hline D.4-4 & 3 & $\begin{array}{l}\text { What if there is a } \\
\text { failure in the } \\
\text { Distillation Column? }\end{array}$ & $\begin{array}{l}\text { Catastrophic failure of the } \\
\text { vessel. }\end{array}$ & $\begin{array}{l}\text { Very } \\
\text { Unlikely }\end{array}$ & Energetic event - failure of V-184 & $\begin{array}{l}\text { V-184 Design pressure } \\
\text { Pressure Test Procedure. } \\
\text { Operating within design parameters } \\
\text { - overpressure over temperature } \\
\text { alarms and controls. }\end{array}$ & $\begin{array}{l}\mathrm{C} \\
\mathrm{C}\end{array}$ & \\
\hline D.4-5 & 3 & $\begin{array}{l}\text { What if there is a flame } \\
\text { impingement due to a } \\
\text { flammable liquid fire? }\end{array}$ & $\begin{array}{l}\text { Catastrophic failure of the } \\
\text { vessel. }\end{array}$ & $\begin{array}{l}\text { Extremely } \\
\text { Unlikely }\end{array}$ & Energetic event - failure of V-184 & $\begin{array}{l}\text { Design of distillation skid } \\
\text { components pressure components. } \\
\text { Enclosure Design - Class } 1 \text { Div } 2 . \\
\text { Flame detection inside enclosure. } \\
\text { Flammable vapor monitor on skid. } \\
\text { Fire suppression system in } \\
\text { enclosure. } \\
\text { Operator response and emergency } \\
\text { stop. }\end{array}$ & $\mathrm{C}$ & \\
\hline D.4-6 & 3 & $\begin{array}{l}\text { What if you lose } \\
\text { heaters? }\end{array}$ & $\begin{array}{l}\text { Loss of power to heaters or } \\
\text { heaters fail. }\end{array}$ & Likely & $\begin{array}{l}\text { Process upset (see previous loss } \\
\text { of heater hazards) }\end{array}$ & & & \\
\hline D.4-7 & 3 & $\begin{array}{l}\text { What if there is a leak } \\
\text { in the low pressure vent } \\
\text { system? }\end{array}$ & $\begin{array}{l}\text { Failure at a connection to } \\
\text { common vent line and } \\
\text { release of flammable } \\
\text { liquids/vapor to enclosure. }\end{array}$ & $\begin{array}{l}\text { Very } \\
\text { Unlikely }\end{array}$ & $\begin{array}{l}\text { Flammable atmosphere. } \\
\text { Flammable atmosphere. } \\
\text { Flammable vapors in enclosure. }\end{array}$ & $\begin{array}{l}\text { Design of vent system. } \\
\text { Enclosure Ventilation System. } \\
\text { Enclosure Design - Class 1 Div } 2 . \\
\text { Flammable vapor monitor skid. }\end{array}$ & $\mathrm{C}$ & \\
\hline D.4-8 & 3 & $\begin{array}{l}\text { What if you don't } \\
\text { switch tanks when they } \\
\text { are full? }\end{array}$ & $\begin{array}{l}\text { Overfill a product tank. } \\
\text { Backup to into vent } \\
\text { header. }\end{array}$ & Likely & $\begin{array}{l}\text { Process upset. Backup to vent } \\
\text { header. }\end{array}$ & $\begin{array}{l}\text { Level indication, } \mathrm{H} / \mathrm{H} \text { and } \mathrm{L} / \mathrm{H} \text { level } \\
\text { alarm. Product tanks are sized for a } \\
\text { run. }\end{array}$ & & \\
\hline D.4-9 & 3 & $\begin{array}{l}\text { What if there is a leak } \\
\text { downstream of } \\
\text { Distillation? }\end{array}$ & $\begin{array}{l}\text { Failure of connection. } \\
\text { Open drain. } \\
\text { Spill of flammable } \\
\text { liquid/vapors) to } \\
\text { containment and/or to }\end{array}$ & Likely & $\begin{array}{l}\text { Flammable atmosphere. } \\
\text { Flammable vapors or liquid in } \\
\text { enclosure. }\end{array}$ & $\begin{array}{l}\text { Pressure test Procedure. } \\
\text { Design of distillation skid } \\
\text { components. } \\
\text { Enclosure Ventilation System. } \\
\text { Enclosure Design - Class 1 Div } 2 .\end{array}$ & $\begin{array}{l}\mathrm{C} \\
\mathrm{C} \\
\mathrm{C}\end{array}$ & \\
\hline
\end{tabular}

Page 55 of 98 


\section{Hydrotreater/Distillation Column Hazard Analysis Report}

Table 3-4. What-If Hazards Analysis Results

\begin{tabular}{|c|c|c|c|c|c|c|c|c|}
\hline \multicolumn{9}{|c|}{$\begin{array}{l}\text { Distillation Process Step 4. Operation } \\
\text { 1) Set feed rate badger to target feed rate. 2) Turn on and prime bottoms level control pump to target setpoint. 3) Monitor liquid level on bottoms and distillate tanks, and switch to } \\
\text { alternate tank when full. 4) Monitor feed tank level. }\end{array}$} \\
\hline \multicolumn{2}{|c|}{$\begin{array}{l}\text { Hazard ID/ } \\
\text { Process } \\
\text { Step }\end{array}$} & \multirow[t]{2}{*}{ What if: } & \multirow{2}{*}{$\begin{array}{l}\text { Hazardous Scenario } \\
\text { enclosure. }\end{array}$} & \multirow[t]{2}{*}{$\begin{array}{l}\text { Likeli- } \\
\text { hood }\end{array}$} & \multirow[t]{2}{*}{ Consequences } & \multicolumn{2}{|l|}{$\begin{array}{l}\text { Hazard Controls } \\
\text { C = Critical Control }\end{array}$} & \multirow[t]{2}{*}{ Comments } \\
\hline & & & & & & $\begin{array}{l}\text { Flammable vapor monitor skid. } \\
\text { Containment pan on skid that could } \\
\text { capture the spill. }\end{array}$ & & \\
\hline $\begin{array}{l}\text { D.4- } \\
10\end{array}$ & 3 & $\begin{array}{l}\text { What if bypass valve is } \\
\text { open? }\end{array}$ & $\begin{array}{l}\text { Bypass valve is opened or } \\
\text { fails. }\end{array}$ & Likely & $\begin{array}{l}\text { Process upset. Higher than } \\
\text { expected flow rate in distillation } \\
\text { column }\end{array}$ & $\begin{array}{l}\text { Flow indication. } \\
\text { Other controls for higher than } \\
\text { expected flow (see startup controls) }\end{array}$ & & \\
\hline $\begin{array}{l}\text { D.4- } \\
11\end{array}$ & 3 & $\begin{array}{l}\text { What if there is a } \\
\text { failure in the pressure } \\
\text { boundary? }\end{array}$ & $\begin{array}{l}\text { Failure in pressure } \\
\text { boundary results in release } \\
\text { of flammable liquid/vapors }\end{array}$ & $\begin{array}{l}\text { Very } \\
\text { Unlikely }\end{array}$ & $\begin{array}{l}\text { Flammable atmosphere. } \\
\text { Fire or flammable atmosphere in } \\
\text { enclosure. }\end{array}$ & $\begin{array}{l}\text { Pressure Test Procedure. } \\
\text { Design of distillation skid } \\
\text { components. } \\
\text { Enclosure Design - Class } 1 \text { Div } 2 . \\
\text { Enclosure Ventilation System. } \\
\text { Flammable vapor monitor on skid. }\end{array}$ & \begin{tabular}{l|}
$\mathrm{C}$ \\
$\mathrm{C}$
\end{tabular} & \\
\hline $\begin{array}{l}\text { D.4- } \\
12\end{array}$ & 3 & $\begin{array}{l}\text { What if there is a } \\
\text { failure in the pressure } \\
\text { boundary? }\end{array}$ & $\begin{array}{l}\text { Failure of water jacket } \\
\text { pressure boundary, leak } \\
\text { into distillation system. }\end{array}$ & $\begin{array}{l}\text { Very } \\
\text { Unlikely }\end{array}$ & $\begin{array}{l}\text { Process upset. Steam, water } \\
\text { vapor into system. } \\
\text { Eventual leak of product back } \\
\text { into the chilled water reservoir } \\
\text { outside enclosure. }\end{array}$ & $\begin{array}{l}\text { Pressure Test Procedure. } \\
\text { Design of distillation skid } \\
\text { components. } \\
\text { Low level indication on Chiller } \\
\text { system. } \\
\text { Flow monitor, temperature alarm on } \\
\text { Chilled Water system. Manual flow } \\
\text { indicator FIC-8001 (would not see } \\
\text { at computer). }\end{array}$ & & \\
\hline $\begin{array}{l}\text { D.4- } \\
13\end{array}$ & 3 & $\begin{array}{l}\text { Over pressure of V-191 } \\
\text { thru V-194 due to low } \\
\text { pressure nitrogen? }\end{array}$ & $\begin{array}{l}\text { Failure in supply (Nitrogen } \\
\text { Tank) regulator results in } \\
\text { over pressurization of V- } \\
191-\mathrm{V}-194 \text { due to } \\
\text { excessive nitrogen } \\
\text { pressure. }\end{array}$ & Unlikely & $\begin{array}{l}\text { Energetic event - failure of low } \\
\text { pressure system (>100 psi) }\end{array}$ & $\begin{array}{l}\text { Pressure regulation of the supply to } \\
100 \text { psig. } \\
\text { Pressure regulation (PCV-9006) set } \\
\text { at } 10 \text { psig regulates downstream } \\
\text { system pressure) } \\
\text { Pressure regulator to offgas vent } \\
\text { header (PCV-9008) set at } 15 \text { psig. } \\
\text { Low pressure component PRVs set } \\
\text { at } \leq 100 \text { psig. } \\
\text { Design of Low pressure } \\
\text { components. } \\
\text { Pressure Test Procedure. }\end{array}$ & $\mathrm{C}$ & \\
\hline
\end{tabular}




\section{Distillation Process Step 5. Shutdown}

1) Turn off still heater and jacket. 2) Halt feed pump and set feed badger to zero. 3) Close reflux badger. 4) Set reflux level control to zero to drain reflux glass into distillate product. 5)

5) Turn off reflux pump after low level indicator. 6) Set bottoms level control to zero. 7)Turn off bottoms level pump after low level indictor. 8) Turn on nitrogen sweep to low level.

\begin{tabular}{|c|c|c|c|c|c|c|c|c|}
\hline $\begin{array}{l}\text { Hazard } \\
\text { Process } \\
\text { Step }\end{array}$ & & What if: & Hazardous Scenario & $\begin{array}{l}\text { Likeli- } \\
\text { hood }\end{array}$ & Consequences & $\begin{array}{l}\text { Hazard Controls } \\
\text { C = Critical Control }\end{array}$ & & Comments \\
\hline D.5-1 & 1 & $\begin{array}{l}\text { What if you fail to off } \\
\text { heater and jacket before } \\
\text { stopping flow? }\end{array}$ & $\begin{array}{l}\text { Shut down pumps before } \\
\text { the heaters are shutdown. }\end{array}$ & Likely & (see boil off of columns) & & & \\
\hline D.5-2 & & $\begin{array}{l}\text { What if you run out of } \\
\text { product? }\end{array}$ & & & (see boil off of column) & & & \\
\hline D.5-3 & 2 & $\begin{array}{l}\text { What if you fail to stop } \\
\text { flow? }\end{array}$ & & & $\begin{array}{l}\text { (see overfill of column or loss of } \\
\text { heaters) }\end{array}$ & & & \\
\hline D.5-4 & 3 & $\begin{array}{l}\text { What if you fail to close } \\
\text { reflux badger? }\end{array}$ & Failure to close FV-8027. & Likely & $\begin{array}{l}\text { Process upset. Loss of some } \\
\text { product. }\end{array}$ & & & \\
\hline D.5-5 & 3 & $\begin{array}{l}\text { What if you close } \\
\text { reflux badger too early? }\end{array}$ & Close FV-8027 too early. & Likely & $\begin{array}{l}\text { Process upset. Minor impact on } \\
\text { product quality. }\end{array}$ & & & \\
\hline D.5-6 & 4 & $\begin{array}{l}\text { What if you close } \\
\text { depressurize reflux? }\end{array}$ & $\begin{array}{l}\text { Failure to set reflux level } \\
\text { control to zero. }\end{array}$ & Likely & $\begin{array}{l}\text { Process upset. Loss of some } \\
\text { product }\end{array}$ & & & \\
\hline D.5-7 & 4 & $\begin{array}{l}\text { What if you open } \\
\text { bypass to drain reflux } \\
\text { (while pressurized)? }\end{array}$ & Drain too early. & Likely & $\begin{array}{l}\text { Flammable atmosphere. } \\
\text { Potential spill of flammable } \\
\text { liquids to enclosure }\end{array}$ & $\begin{array}{l}\text { Enclosure Ventilation System. } \\
\text { Enclosure Design - Class } 1 \text { Div } 2 . \\
\text { Flammable vapor monitor skid. } \\
\text { Containment pan on skid that could } \\
\text { capture the spill. }\end{array}$ & $\begin{array}{l}\mathrm{C} \\
\mathrm{C}\end{array}$ & \\
\hline D.5-8 & & $\begin{array}{l}\text { What if you fail to } \\
\text { correctly align during } \\
\text { unloading? }\end{array}$ & $\begin{array}{l}\text { Failure to properly connect } \\
\text { to Apache tank. }\end{array}$ & Likely & $\begin{array}{l}\text { Flammable atmosphere. } \\
\text { Spills of flammable liquid into } \\
\text { enclosure }\end{array}$ & $\begin{array}{l}\text { Enclosure Ventilation System. } \\
\text { Enclosure Design - Class } 1 \text { Div } 2 .\end{array}$ & & \\
\hline D.5-9 & & $\begin{array}{l}\text { What if you over fill } \\
\text { Apache tank? }\end{array}$ & $\begin{array}{l}\text { Overfill product to vent } \\
\text { header. }\end{array}$ & Likely & & & & \\
\hline
\end{tabular}

\section{Utilities: Process Ventilation, Enclosure Ventilation, Compressed Air, Hydrogen, Nitrogen, Power,}

\begin{tabular}{|c|c|c|c|c|c|c|}
\hline $\begin{array}{l}\text { Hazard ID/ } \\
\text { Process } \\
\text { Step }\end{array}$ & What if: & Hazardous Scenario & $\begin{array}{l}\text { Likeli- } \\
\text { hood }\end{array}$ & Consequences & $\begin{array}{l}\text { Hazard Controls } \\
\mathrm{C}=\text { Critical Control }\end{array}$ & Comments \\
\hline U-1 & $\begin{array}{l}\text { What if loss (blockage) } \\
\text { of process vent header? }\end{array}$ & $\begin{array}{l}\text { Overflow of flammable } \\
\text { liquids into vent header. } \\
\text { Would require continued } \\
\text { operations for extended }\end{array}$ & $\begin{array}{l}\text { Very } \\
\text { Unlikely }\end{array}$ & $\begin{array}{l}\text { Spray or spill. } \\
\text { Flammable liquid accumulation in } \\
\text { stack in unoccupied area vapors } \\
\text { would dissipate out the stack. }\end{array}$ & (see overflow scenarios) & \\
\hline
\end{tabular}


Hydrotreater/Distillation Column Hazard Analysis Report

Table 3-4. What-If Hazards Analysis Results

\begin{tabular}{|c|c|c|c|c|c|c|c|}
\hline $\begin{array}{l}\text { Hazard ID/ } \\
\text { Process } \\
\text { Step }\end{array}$ & \multirow[t]{2}{*}{ What if: } & \multirow{2}{*}{\begin{tabular}{|l|} 
Hazardous Scenario \\
period of time.
\end{tabular}} & \multirow[t]{2}{*}{$\begin{array}{l}\text { Likeli- } \\
\text { hood }\end{array}$} & \multirow[t]{2}{*}{ Consequences } & \multicolumn{2}{|l|}{$\begin{array}{l}\text { Hazard Controls } \\
\text { C = Critical Control }\end{array}$} & \multirow[t]{2}{*}{ Comments } \\
\hline & & & & & & & \\
\hline $\mathrm{U}-2$ & $\begin{array}{l}\text { What if loss (blockage) } \\
\text { of process vent header? }\end{array}$ & Loss of vent header. & & $\begin{array}{l}\text { Process upset. Pressurize low } \\
\text { pressure side WTM-152, V-153, } \\
\text { LG-147, LG-142, V-140 and } \\
\text { reactor and all associated piping. }\end{array}$ & $\begin{array}{l}\text { (See earlier (system specific) block } \\
\text { flow events). }\end{array}$ & & \\
\hline U-3 & $\begin{array}{l}\text { What if ventilation } \\
\text { flowpath is lost? }\end{array}$ & $\begin{array}{l}\text { Failure of stack due to high } \\
\text { wind. }\end{array}$ & $\begin{array}{l}\text { Very } \\
\text { Unlikely }\end{array}$ & $\begin{array}{l}\text { Blockage of vent flow due to } \\
\text { collapsed or bent stack. } \\
\text { Loss of ventilation. Potential loss } \\
\text { of flow or back flow into vent } \\
\text { header. Blockage of exhaust gas } \\
\text { flow and potential creation of } \\
\text { flammable environment in } \\
\text { enclosure and vent stack. }\end{array}$ & $\begin{array}{l}\text { Exhaust flow switch initiates } \\
\text { Scenario A on loss of flow. }\end{array}$ & & \\
\hline $\mathrm{U}-4$ & $\begin{array}{l}\text { What if ventilation } \\
\text { flowpath is lost? }\end{array}$ & $\begin{array}{l}\text { Failure of stack due to high } \\
\text { wind. }\end{array}$ & $\begin{array}{l}\text { Very } \\
\text { Unlikely }\end{array}$ & $\begin{array}{l}\text { Process upset. No immediate } \\
\text { release. } \\
\text { Break of stack at ground level. } \\
\text { Vent of effluent at ground level. } \\
\text { Potential loss of ventilation fan. }\end{array}$ & Design of Stack. & & \\
\hline U-5 & $\begin{array}{l}\text { What if ventilation is } \\
\text { lost? }\end{array}$ & Failure of ventilation fan. & Likely & $\begin{array}{l}\text { Potential flammable } \\
\text { concentrations of hydrogen or } \\
\text { vapors in stack. Vapors would } \\
\text { dissipate out the stack. }\end{array}$ & $\begin{array}{l}\text { Loss of ventilation fan trips process } \\
\text { controls. }\end{array}$ & & \\
\hline U-6 & $\begin{array}{l}\text { What if loss of } \\
\text { Enclosure Ventilation? }\end{array}$ & $\begin{array}{l}\text { Enclosure ventilation is } \\
\text { lost. }\end{array}$ & Likely & $\begin{array}{l}\text { Loss of environmental control in } \\
\text { enclosure. }\end{array}$ & $\begin{array}{l}\text { Loss of ventilation shuts off the } \\
\text { hydrogen flow, the heaters and the } \\
\text { pumps via shutdown scenario A. }\end{array}$ & & \\
\hline U-7 & $\begin{array}{l}\text { What if relief header } \\
\text { flow is lost? } \\
\text { Mud daubers } \\
\text { commonly plug drain at } \\
382 \text { (100 psi) }\end{array}$ & $\begin{array}{l}\text { Relief header is blocked by } \\
\text { bird/bees nests. }\end{array}$ & Unlikely & Inadequate pressure relief. & $\begin{array}{l}\text { Administrative controls to check } \\
\text { relief header. } \\
\text { Design of system includes bird } \\
\text { screens, double release path at top. } \\
\text { Design pressure of knockout pot is } \\
12 \text { psi. }\end{array}$ & & \\
\hline U-8 & $\begin{array}{l}\text { What if relief header } \\
\text { flow is activated? }\end{array}$ & $\begin{array}{l}\text { Activation of pressure } \\
\text { relief }\end{array}$ & Likely & $\begin{array}{l}\text { Flammable atmosphere. } \\
\text { Potential flammable atmosphere } \\
\text { in relief header and knockout pot. }\end{array}$ & Design of knockout pot and lines. & $\mathrm{C}$ & $\begin{array}{l}\text { Auto-ignition would } \\
\text { require high } \\
\text { temperature. }\end{array}$ \\
\hline U-9 & $\begin{array}{l}\text { What if there is a pool } \\
\text { Fire in Enclosure }\end{array}$ & $\begin{array}{l}\text { Leak of flammable liquid } \\
\text { accumulation in enclosure, } \\
\text { secondary containment and } \\
\text { subsequent pool fire. }\end{array}$ & Unlikely & $\begin{array}{l}\text { Energetic Event. } \\
\text { Potential impingement on vessels, } \\
\text { lines, or structure. } \\
\text { Structural failures and } \\
\text { impingement could lead to line or }\end{array}$ & $\begin{array}{l}\text { Design of Product Tank (V-160 } \\
\text { A/B). } \\
\text { Pressure Test Procedure. } \\
\text { Distillation skid has separate } \\
\text { containment from the hydrotreater }\end{array}$ & $\mathrm{C}$ & \\
\hline
\end{tabular}

Page 58 of 98 
Hydrotreater/Distillation Column Hazard Analysis Report

Table 3-4. What-If Hazards Analysis Results

\begin{tabular}{|c|c|c|c|c|c|c|c|}
\hline \multirow[t]{2}{*}{$\begin{array}{l}\text { Hazard II } \\
\text { Process } \\
\text { Step }\end{array}$} & \multirow[t]{2}{*}{ What if: } & \multirow[t]{2}{*}{ Hazardous Scenario } & \multirow[t]{2}{*}{$\begin{array}{l}\text { Likeli- } \\
\text { hood }\end{array}$} & \multirow{2}{*}{$\begin{array}{l}\text { Consequences } \\
\text { vessel ruptures. }\end{array}$} & \multicolumn{2}{|l|}{$\begin{array}{l}\text { Hazard Controls } \\
\text { C = Critical Control }\end{array}$} & \multirow[t]{2}{*}{ Comments } \\
\hline & & & & & $\begin{array}{l}\text { skid. } \\
\text { Enclosure Design - Class } 1 \text { Div } 2 \\
\text { Flammable vapor monitor on skid } \\
\text { Flame detection inside enclosure. } \\
\text { Fire suppression system in enclosure } \\
\text { Reactor column is shielded by } \\
\text { furnace enclosure which would limit } \\
\text { exposure and rapid temperature rise } \\
\text { to heat up the vessel. } \\
\text { Operator response and emergency } \\
\text { stop. }\end{array}$ & & \\
\hline $\mathrm{U}-10$ & $\begin{array}{l}\text { What if there is an } \\
\text { impingement (jet) fire } \\
\text { (hydrogen or } \\
\text { pressurized flammable } \\
\text { liquid line) in } \\
\text { Enclosure? }\end{array}$ & $\begin{array}{l}\text { Line leak of hydrogen } \\
\text { supply or pressurized } \\
\text { flammable liquid line. }\end{array}$ & Unlikely & $\begin{array}{l}\text { Energetic Event. Potential } \\
\text { impingement on vessels, lines, or } \\
\text { structure. } \\
\text { Structural failures and } \\
\text { impingement could lead to line or } \\
\text { vessel ruptures. }\end{array}$ & $\begin{array}{l}\text { Design of hydrogen pipe system. } \\
\text { Excess flow valve on hydrogen } \\
\text { supply. } \\
\text { Flame detection inside enclosure. } \\
\text { Hydrogen monitor on skid and } \\
\text { enclosure. } \\
\text { Fire suppression system in } \\
\text { enclosure. } \\
\text { Reactor column shielded by furnace } \\
\text { enclosure which would limit } \\
\text { exposure and rapid temperature rise } \\
\text { to heat up the vessel. } \\
\text { Operator response and emergency } \\
\text { stop. }\end{array}$ & $\begin{array}{l}\mathrm{C} \\
\mathrm{C}\end{array}$ & \\
\hline $\mathrm{U}-11$ & $\begin{array}{l}\text { What if there is a fire in } \\
\text { electrical power } \\
\text { cabinets inside } \\
\text { enclosure? }\end{array}$ & $\begin{array}{l}\text { Loss of function of various } \\
\text { components (pumps, } \\
\text { valves, control systems). } \\
\text { Potential multiple spurious } \\
\text { actions. }\end{array}$ & $\begin{array}{l}\text { Very } \\
\text { Unlikely }\end{array}$ & $\begin{array}{l}\text { (The scenarios identified for other } \\
\text { hazards, including the bounding } \\
\text { scenario of vessel over } \\
\text { pressurization.) }\end{array}$ & $\begin{array}{l}\text { Vessel protection, pressure relief. } \\
\text { Enclosure Design. Design of } \\
\text { electrical cabinets. All cables in } \\
\text { conduit. }\end{array}$ & & $\begin{array}{l}\text { Two power cabinets. } \\
\text { Two separate } \\
\text { instrument cabinets. }\end{array}$ \\
\hline $\mathrm{U}-12$ & $\begin{array}{l}\text { What if the water mist } \\
\text { system actuates? }\end{array}$ & $\begin{array}{l}\text { Inadvertent actuation } \\
\text { results in water mist during } \\
\text { operation. }\end{array}$ & Unlikely & $\begin{array}{l}\text { Process upset. No immediate } \\
\text { release. Spraying water on hot } \\
\text { systems, leading to loss of } \\
\text { pressure boundary due to thermal } \\
\text { stress (e.g., reactor and distillation } \\
\text { columns). }\end{array}$ & $\begin{array}{l}\text { Column design. } \\
\text { The mist system is a low volume } \\
\text { system. } \\
\text { Top of vessels are not insulated and } \\
\text { could be at } 160 \mathrm{C} \text {. } \\
\text { Columns are not constrained. }\end{array}$ & & \\
\hline $\mathrm{U}-13$ & $\begin{array}{l}\text { What if the water mist } \\
\text { system actuates? }\end{array}$ & $\begin{array}{l}\text { Inadvertent actuation } \\
\text { results in water mist during }\end{array}$ & Unlikely & $\begin{array}{l}\text { Process upset. No immediate } \\
\text { release. Shorting in electrical }\end{array}$ & Cabinets are sealed and purged. & & \\
\hline
\end{tabular}


Hydrotreater/Distillation Column Hazard Analysis Report

Table 3-4. What-If Hazards Analysis Results

\begin{tabular}{|c|c|c|c|c|c|c|}
\hline $\begin{array}{l}\text { Hazar } \\
\text { Proces } \\
\text { Step }\end{array}$ & What if: & Hazardous Scenario & $\begin{array}{l}\text { Likeli- } \\
\text { hood }\end{array}$ & Consequences & $\begin{array}{l}\text { Hazard Controls } \\
\text { C = Critical Control }\end{array}$ & Comments \\
\hline & & operation. & & cabinets. & & \\
\hline U-14 & $\begin{array}{l}\text { What if Fire in } \\
\text { enclosure? }\end{array}$ & $\begin{array}{l}\text { Fire department quenches } \\
\text { vessel. }\end{array}$ & & $\begin{array}{l}\text { Process upset. No immediate } \\
\text { release. Spraying water on hot } \\
\text { systems, leading to loss of } \\
\text { pressure boundary due to thermal } \\
\text { stress (e.g., reactor and distillation } \\
\text { columns). Note: Standard } \\
\text { response to vessels in fire } \\
\text { including liquid gases is to spray } \\
\text { water and move to safe distance. }\end{array}$ & $\begin{array}{l}\text { Notification of fire department } \\
\text { would only occur with initiation of } \\
\text { Scenario C. }\end{array}$ & \\
\hline $\mathrm{U}-15$ & $\begin{array}{l}\text { What if Fire in PDL- } \\
\text { West? }\end{array}$ & $\begin{array}{l}\text { Fire outside enclosure } \\
\text { initiates evacuation. }\end{array}$ & Likely & $\begin{array}{l}\text { Process upset. No immediate } \\
\text { release. Evacuation of PDL-West } \\
\text { resulting in unattended operation } \\
\text { of the system. }\end{array}$ & $\begin{array}{l}\text { Fire alarm system activation initiates } \\
\text { Scenario A. }\end{array}$ & \\
\hline U-16 & $\begin{array}{l}\text { What if process control } \\
\text { is lost? }\end{array}$ & $\begin{array}{l}\text { Loss of process control due } \\
\text { to PLC failure. }\end{array}$ & Unlikely. & $\begin{array}{l}\text { Process upset. No immediate } \\
\text { release. PLC fails to } \\
\text { indeterminate state. }\end{array}$ & $\begin{array}{l}\text { PLC design such that all control } \\
\text { goes to their failed states (fail safe) } \\
\text { as controlled by skid. } \\
\text { PLC is protected by UPS. }\end{array}$ & \\
\hline $\mathrm{U}-17$ & $\begin{array}{l}\text { What If you lose power } \\
\text { and you are in the } \\
\text { middle of the run? }\end{array}$ & $\begin{array}{l}\text { Short term loss of power. } \\
\text { (Seconds- expected } \\
\text { monthly). }\end{array}$ & Likely & $\begin{array}{l}\text { Process upset. No immediate } \\
\text { release. VFD on exhaust fan goes } \\
\text { offline on a fault but hydrotreater } \\
\text { system does not recognize it. }\end{array}$ & $\begin{array}{l}\text { Process monitoring and control on } \\
\text { UPS and still available. Loss of } \\
\text { ventilation shuts off the hydrogen } \\
\text { flow, the heaters and the pumps via } \\
\text { shutdown scenario A. Process can } \\
\text { start on resumption of ventilation } \\
\text { flow. }\end{array}$ & $\begin{array}{l}\text { Back pressure } \\
\text { regulator allows } \\
\text { reactor to lose } \\
\text { pressure slowly. }\end{array}$ \\
\hline U-18 & $\begin{array}{l}\text { What if longer term } \\
\text { loss of power and you } \\
\text { are in the middle of the } \\
\text { run? }\end{array}$ & $\begin{array}{l}\text { Longer term loss of power } \\
\text { (minutes - expected a few } \\
\text { times a year). }\end{array}$ & Likely & $\begin{array}{l}\text { Process upset. No immediate } \\
\text { release. Loss of exhaust fan and } \\
\text { compressed air. Loss of MAU. } \\
\text { Loss of normal power lighting. }\end{array}$ & $\begin{array}{l}\text { Process monitoring on UPS and still } \\
\text { available. E-Stop maintained. Loss } \\
\text { of ventilation shuts off the hydrogen } \\
\text { flow, the heaters and the pumps via } \\
\text { shutdown scenario A. Alarm on Z } \\
\text { purge. Reactor pressure maintained } \\
\text { in stable condition with slow decay. }\end{array}$ & \\
\hline U-19 & $\begin{array}{l}\text { What if longer term } \\
\text { loss of power and you } \\
\text { are in the middle of the }\end{array}$ & $\begin{array}{l}\text { Extended power outage (> } \\
\text { than UPS capacity). }\end{array}$ & Likely & $\begin{array}{l}\text { Process upset. No immediate } \\
\text { release. Forced Shutdown. Loss } \\
\text { of process monitoring and control. }\end{array}$ & $\begin{array}{l}\text { Procedures to initiate shut-down. } \\
\text { Loss of fire system UPS battery } \\
\text { would result in opening XV-4020. }\end{array}$ & \\
\hline
\end{tabular}


Hydrotreater/Distillation Column Hazard Analysis Report

Table 3-4. What-If Hazards Analysis Results

\begin{tabular}{|c|c|c|c|c|c|c|c|}
\hline \multirow[t]{2}{*}{$\begin{array}{l}\text { Hazard ID } \\
\text { Process } \\
\text { Step }\end{array}$} & \multirow{2}{*}{$\begin{array}{l}\text { What if: } \\
\text { run? }\end{array}$} & \multirow[t]{2}{*}{ Hazardous Scenario } & \multirow[t]{2}{*}{$\begin{array}{l}\text { Likeli- } \\
\text { hood }\end{array}$} & \multirow{2}{*}{$\begin{array}{l}\text { Consequences } \\
\text { Loss of exhaust fan and } \\
\text { compressed air. Loss of MAU. } \\
\text { Loss of normal power lighting. }\end{array}$} & \multicolumn{2}{|l|}{$\begin{array}{l}\text { Hazard Controls } \\
\text { C = Critical Control }\end{array}$} & \multirow[t]{2}{*}{ Comments } \\
\hline & & & & & & & \\
\hline $\mathrm{U}-20$ & $\begin{array}{l}\text { If there is loss } \\
\text { instrument air, what } \\
\text { happens from system } \\
\text { overall? }\end{array}$ & $\begin{array}{l}\text { Loss of air compressor. } \\
\text { Failure in the compressed } \\
\text { air delivery system. }\end{array}$ & Likely & $\begin{array}{l}\text { Process upset. No immediate } \\
\text { release. Pneumatic hydrogen and } \\
\text { nitrogen valves close, badger } \\
\text { valves close. The ISCO pump } \\
\text { valves would close. Loss of Z } \\
\text { purge. }\end{array}$ & $\begin{array}{l}\text { Enclosure ventilation is maintained. } \\
\text { E-Stop functionality is maintained. } \\
\text { Alarm on z-purge. } \\
\text { Alarm notification on loss of } \\
\text { hydrogen. Reactor pressure } \\
\text { boundary is stable. Distillation } \\
\text { pressure boundary is stable. }\end{array}$ & & \\
\hline $\mathrm{U}-21$ & $\begin{array}{l}\text { What if there is loss of } \\
\text { the chilled water? }\end{array}$ & $\begin{array}{l}\text { Loss of cooling to V-140 } \\
\text { results in excessive vapors } \\
\text { and steam carryover to off } \\
\text { gas system. }\end{array}$ & Likely & $\begin{array}{l}\text { Process upset. Condensation leads } \\
\text { to potential plug of off gas } \\
\text { system. }\end{array}$ & $\begin{array}{l}\text { Switch over to tempered water. See } \\
\text { controls for loss of off-gas } \\
\text { scenarios. }\end{array}$ & & \\
\hline $\mathrm{U}-22$ & $\begin{array}{l}\text { What if there is loss of } \\
\text { the chilled water? }\end{array}$ & $\begin{array}{l}\text { Loss of cooling to V-140 } \\
\text { results in steam generation } \\
\text { in the water jacket around } \\
\text { V-140. }\end{array}$ & Likely & $\begin{array}{l}\text { Process upset. Blow-down of } \\
\text { steam into the chilled water } \\
\text { system Z-172. }\end{array}$ & $\begin{array}{l}\text { Switch over to tempered water. } \\
\text { Procedural control over restart of } \\
\text { system. (Check integrity of hoses) }\end{array}$ & & \\
\hline $\mathrm{U}-23$ & $\begin{array}{l}\text { What if there is loss of } \\
\text { the tempered water? }\end{array}$ & $\begin{array}{l}\text { Tempered water loss. } \\
\text { Results in difficulty in } \\
\text { pumping bio-oil and heavy } \\
\text { products. }\end{array}$ & Likely & $\begin{array}{l}\text { Process upset. Overheating of P- } \\
182 .\end{array}$ & Procedural steps. & & \\
\hline $\mathrm{U}-24$ & $\begin{array}{l}\text { What if there is a } \\
\text { hydrogen line leak } \\
\text { outside the enclosure? }\end{array}$ & $\begin{array}{l}\text { Failure in the hydrogen } \\
\text { line. }\end{array}$ & $\begin{array}{l}\text { Very } \\
\text { Unlikely }\end{array}$ & $\begin{array}{l}\text { Flammable atmosphere -PDL. } \\
\text { Release of hydrogen to PDL. } \\
\text { Loss of hydrogen to reactor. }\end{array}$ & $\begin{array}{l}\text { It is one piece of tubing ( } ~ 17 \text { feet) } \\
\text { rated at maximum pressure. } \\
\text { Located in a tray sitting in a tube } \\
\text { holder supported across the length. } \\
\text { It is at } 13 \text { foot elevation, in a tray, } \\
\text { protected from edge of building. } \\
\text { Excess flow valve on hydrogen } \\
\text { supply (catastrophic break). } \\
\text { Makeup air unit for enclosure. } \\
\text { Passive PDL roof vents. }\end{array}$ & & \\
\hline $\mathrm{U}-25$ & $\begin{array}{l}\text { What if there is a } \\
\text { hydrogen line leak in } \\
\text { the enclosure? }\end{array}$ & $\begin{array}{l}\text { Failure in the hydrogen } \\
\text { line. }\end{array}$ & $\begin{array}{l}\text { Very } \\
\text { Unlikely }\end{array}$ & $\begin{array}{l}\text { Flammable atmosphere. } \\
\text { Process impacts same as loss of } \\
\text { hydrogen flow to reactor. }\end{array}$ & $\begin{array}{l}\text { Design Hydrogen pipe system. } \\
\text { Excess flow valve on hydrogen } \\
\text { supply (catastrophic break). } \\
\text { Enclosure Design - Class } 1 \text { Division } \\
2 .\end{array}$ & $\begin{array}{l}\mathrm{C} \\
\mathrm{C}\end{array}$ & \\
\hline
\end{tabular}


Hydrotreater/Distillation Column Hazard Analysis Report

Table 3-4. What-If Hazards Analysis Results

\begin{tabular}{|c|c|c|c|c|c|c|}
\hline \multirow[t]{2}{*}{$\begin{array}{l}\text { Hazard II } \\
\text { Process } \\
\text { Step }\end{array}$} & \multirow[t]{2}{*}{ What if: } & \multirow[t]{2}{*}{ Hazardous Scenario } & \multirow[t]{2}{*}{$\begin{array}{l}\text { Likeli- } \\
\text { hood }\end{array}$} & \multirow[t]{2}{*}{ Consequences } & $\begin{array}{l}\text { Hazard Controls } \\
\text { C = Critical Control }\end{array}$ & \multirow[t]{2}{*}{ Comments } \\
\hline & & & & & $\begin{array}{l}\text { Enclosure Ventilation System } \\
\text { Hydrogen monitors on skid and in } \\
\text { enclosure. } \\
\text { Flame detection inside enclosure. } \\
\text { Fire suppression system in } \\
\text { enclosure. }\end{array}$ & \\
\hline U-26 & $\begin{array}{l}\text { What if hydrogen } \\
\text { pressure goes down? - } \\
\text { How to regulate }\end{array}$ & Addressed previously. & & & & \\
\hline $\mathrm{U}-27$ & $\begin{array}{l}\text { What if temperature too } \\
\text { high in the hi-bay? }\end{array}$ & $\begin{array}{l}\text { Loss of HVAC } \\
\text { conditioning - high } \\
\text { temperature. }\end{array}$ & Likely & $\begin{array}{l}\text { Process upset. Potential failure of } \\
\text { PLC or instrumentation in } \\
\text { enclosure. }\end{array}$ & $\begin{array}{l}\text { Initiation of shutdown sequence } \\
\text { based on personnel comfort } \\
\text { temperature. }\end{array}$ & $\begin{array}{l}\text { Personnel will get } \\
\text { too hot before } \\
\text { electronics fail }\end{array}$ \\
\hline $\mathrm{U}-28$ & $\begin{array}{l}\text { What if temperature too } \\
\text { low in hi-bay? }\end{array}$ & $\begin{array}{l}\text { Loss of HVAC } \\
\text { conditioning - low } \\
\text { temperature. }\end{array}$ & Likely & $\begin{array}{l}\text { Process upset. Potential impact in } \\
\text { PDL-West, freezing due to } \\
\text { continued operation of Enclosure } \\
\text { exhaust air. } \\
\text { Lose ability to operate water mist } \\
\text { system. }\end{array}$ & $\begin{array}{l}\text { Initiation of shutdown sequence } \\
\text { based on personnel comfort } \\
\text { temperature. }\end{array}$ & \\
\hline $\mathrm{U}-29$ & $\begin{array}{l}\text { What if you have a } \\
\text { nitrogen leak into } \\
\text { enclosure? }\end{array}$ & Addressed previously. & Unlikely & $\begin{array}{l}\text { Personnel Exposure. Potential } \\
\text { oxygen deficient atmosphere. }\end{array}$ & Enclosure Ventilation System. & \\
\hline $\mathrm{U}-30$ & $\begin{array}{l}\text { What if nitrogen leaks } \\
\text { into PDL-West? }\end{array}$ & & & $\begin{array}{l}\text { Personnel Exposure Potential } \\
\text { oxygen deficient atmosphere in } \\
\text { PDL-West. }\end{array}$ & & \\
\hline U-31 & $\begin{array}{l}\text { What if operational } \\
\text { upset from other PDL- } \\
\text { West operations? (See } \\
\text { hazardous scenario.) }\end{array}$ & Impact from Crane or load. & Likely & $\begin{array}{l}\text { Flammable atmosphere. } \\
\text { Rupture of process lines or utility } \\
\text { lines leading to release of } \\
\text { flammable gases. Impact to } \\
\text { enclosure, exhaust ducts. }\end{array}$ & Operational restriction on crane use. & \\
\hline $\mathrm{U}-32$ & $\begin{array}{l}\text { What if operational } \\
\text { upset from other PDL- } \\
\text { West operations? (See } \\
\text { hazardous scenario.) }\end{array}$ & $\begin{array}{l}\text { Spill or leak in PDL-West } \\
\text { results in introduction of } \\
\text { flammable or hazardous } \\
\text { vapors to Enclosure. }\end{array}$ & Likely & $\begin{array}{l}\text { Flammable atmosphere. } \\
\text { Flammable or hazardous vapors } \\
\text { in Enclosure. }\end{array}$ & $\begin{array}{l}\text { Flammable vapor monitor. } \\
\text { Enclosure Design - Class } 1 \text { Div } 2 . \\
\text { MCA alarm, } 20 \text { minute bypass timer } \\
\text { until Scenario A is initiated (unless } \\
\text { operator bypasses). }\end{array}$ & \\
\hline U-33 & $\begin{array}{l}\text { What if operational } \\
\text { upset from other PDL- } \\
\text { West operations? (See }\end{array}$ & $\begin{array}{l}\text { Intake vehicle exhaust into } \\
\text { ventilation system. }\end{array}$ & Likely & $\begin{array}{l}\text { Personnel Exposure/Process } \\
\text { upset. Impact to operations staff } \\
\text { in PDL West and within }\end{array}$ & $\begin{array}{l}\text { Administrative Control of vehicles } \\
\text { in vicinity of building intakes (e.g., } \\
\text { Do not park and idle) }\end{array}$ & $\begin{array}{l}\text { Intakes are at ground } \\
\text { level. }\end{array}$ \\
\hline
\end{tabular}


Hydrotreater/Distillation Column Hazard Analysis Report

Table 3-4. What-If Hazards Analysis Results

\begin{tabular}{|c|c|c|c|c|c|c|}
\hline $\begin{array}{l}\text { Hazard ID/ } \\
\text { Process } \\
\text { Step }\end{array}$ & What if: & Hazardous Scenario & $\begin{array}{l}\text { Likeli- } \\
\text { hood }\end{array}$ & Consequences & $\begin{array}{l}\text { Hazard Controls } \\
\text { C = Critical Control }\end{array}$ & Comments \\
\hline & hazardous scenario.) & & & $\begin{array}{l}\text { Enclosure. } \\
\text { Inadvertent actuation of } \\
\text { flammable vapor detection system }\end{array}$ & & \\
\hline U-34 & $\begin{array}{l}\text { What if operational } \\
\text { upset from other PDL- } \\
\text { West operations? (See } \\
\text { hazardous scenario.) }\end{array}$ & $\begin{array}{l}\text { Hot work in PDL-West } \\
\text { results inadvertent flame } \\
\text { detection, actuation of mist } \\
\text { system. }\end{array}$ & Likely & $\begin{array}{l}\text { Process upset. Inadvertent flame } \\
\text { detection, actuation of mist } \\
\text { system during operation (see } \\
\text { above) }\end{array}$ & Hot Work Administrative Control. & \\
\hline U-35 & $\begin{array}{l}\text { What if operational } \\
\text { upset from other PDL- } \\
\text { West operations? (See } \\
\text { hazardous scenario.) }\end{array}$ & $\begin{array}{l}\text { Future chemical fume hood } \\
\text { operations and tie-in. } \\
\text { Includes chemicals like } \\
\text { acetone, sulfide agents }\end{array}$ & Likely & $\begin{array}{l}\text { Flammable atmosphere. } \\
\text { Release of flammable, hazardous } \\
\text { vapors into exhaust system. }\end{array}$ & $\begin{array}{l}\text { Exhaust flow operation. } \\
\text { Administrative control of fume } \\
\text { hood. } \\
\text { Ensure future Tie-ins occur } \\
\text { downstream of the Enclosure }\end{array}$ & \\
\hline
\end{tabular}


Hydrotreater/Distillation Column Hazard Analysis Report Table 3-4. What-If Hazards Analysis Results

This page intentionally left blank 


\subsection{Evaluation of High Hazard Scenarios}

Accident scenarios perceived as having high unmitigated consequences (energetic events with impacts outside the hydrotreater enclosure) were identified for further evaluation of the consequence and adequacy of controls. The following classes of scenarios were identified as being highly energetic and having high consequences and are further evaluated herein:

1. Boiling Liquid Expanding Vapor Explosion (BLEVE)

2. Pressure Vessel Bursts (PVB)

3. Flammable Vapor/Hydrogen leaks leading to deflagrations in the process enclosure (FA)

\subsubsection{Boiling Liquid Expanding Vapor Explosion (BLEVE)}

The hazard analysis identified hazard scenarios potentially resulting in BLEVEs in the hydrotreater reactor and distillation column and in several process vessels.

Of these events, consequences for the hydrotreater reactor (R-130) and distillation column (V-184) are further presented here. These components pose the highest consequences based on heat input, pressure and volume of material.

For the other pressurized process vessels, the possibility of a BLEVE is very remote as there were no identified internal heat inputs which would raise the temperature of the liquid above boiling and the vessels are insulated which would serve to protect them against the consequences of a BLEVE associated with an external fire. BLEVEs are not associated with atmospherically vented vessels unless a mechanism is identified that also results in a complete blockage of the ventilation pathway for the vessel.

\subsubsection{BLEVE Consequence Methodology}

A Boiling Liquid Expanding Vapor Explosion (BLEVE) is the result of the sudden catastrophic failure of a pressurized vessel containing liquid above its atmospheric boiling point. A BLEVE requires that the loss of containment be "sudden" and "significant" in size. Partial failures leading to two-phase jet releases would not be called a BLEVE since it does not represent a sudden loss of containment (CCPS, 2010). Depending on whether the liquid in the vessel is flammable or non-flammable, a BLEVE may include the following effects:

- blast effects (pressure wave due to the rapid vaporization of the liquid)

- missile impacts (fragment and debris throw)

- fireball (thermal hazards)

For analyzing BLEVEs, the process outlined in CCPS, 2010 was followed. Since the distillation column $\mathrm{V}-184$ vessel is comprised of two sections of differing size and wall thickness, the process outlined in CCPS, 2000 was used to calculate the missile fragment range. 
Blast Effects: It was conservatively assumed that the blast effects are based on the work done during an isentropic expansion process and that the energy is based on the combined energy from the liquid and vapor. The explosion energy can be written as:

Explosion Energy, $\mathrm{E}_{\mathrm{ex}}=2 \mathrm{e}_{\mathrm{ex}} \mathrm{m}$

Where:

$2=$ a multiplier for ground effects.

$\mathrm{e}_{\mathrm{ex}} \quad=$ work done, $\mathrm{u} 1-\mathrm{u} 2$, the change in internal energy from state 1 (just before the failure) to state 2 (atmospheric) for both the fluid (f) and gas (g).

$\mathrm{m} \quad=$ mass of fluid released; the volume of fluid/specific volume $\mathrm{V}_{1} / v_{1}$.

$\mathrm{u} 1_{(\mathrm{f}, \mathrm{g})} \quad=$ internal energy of the (fluid, gas) at the initial conditions. These values can be obtained directly from NIST thermodynamic data.

$\mathrm{u} 2_{(\mathrm{f}, \mathrm{g})} \quad=$ internal energy of the (fluid, gas) in the expanded state, adjusting for the flashing fraction.

Where:

$$
\begin{aligned}
& \mathrm{u}_{2 \mathrm{f}}=\left(1-\mathrm{X}_{\mathrm{f}}\right) * \mathrm{u}_{2 \mathrm{f}}+\mathrm{X}_{\mathrm{f}} * \mathrm{u}_{2 \mathrm{~g}} \\
& \mathrm{u}_{2 \mathrm{~g}}=\mathrm{X}_{\mathrm{g}} * \mathrm{u}_{2 \mathrm{f}}+\left(1-\mathrm{X}_{\mathrm{g}}\right) * \mathrm{u}_{2 \mathrm{~g}} \\
& \mathrm{X}_{\mathrm{f}}=\left(\mathrm{s}_{1 \mathrm{f}}-\mathrm{s}_{2 \mathrm{f}}\right) /\left(\mathrm{s}_{2 \mathrm{~g}}-\mathrm{s}_{2 \mathrm{f}}\right) \\
& \mathrm{X}_{\mathrm{g}}=\left(\mathrm{s}_{2 \mathrm{~g}}-\mathrm{s}_{1 \mathrm{f}}\right) /\left(\mathrm{s}_{2 \mathrm{~g}}-\mathrm{s}_{2 \mathrm{f}}\right)
\end{aligned}
$$

Energy available - Per the CCPS, 2010 methodology assuming ductile failure, the energy available is $\mathrm{E}_{\mathrm{ex}, \mathrm{a}}=0.4 * \mathrm{E}_{\mathrm{ex}}$. Recent work by Casal and Salla present BLEVE overpressure estimations based on superheat and state the energy available is 14\% (assumed to be 15\%) of the superheat energy calculated by the isentropic process. Therefore; a range based on the above correlations is provided for each of the BLEVE overpressure calculations.

The scaled standoff distance, $\bar{R}$ of the receptor is then determined by:

$$
\bar{R}=\mathrm{R} *\left[\mathrm{p}_{0} / \mathrm{E}_{\mathrm{ex}, \mathrm{a}}\right]^{1 / 3}
$$

Where:

$$
\begin{aligned}
& \mathrm{R}=\text { distance to receptor } \\
& \mathrm{p}_{0}=\text { atmospheric pressure }
\end{aligned}
$$

The scaled pressure $\bar{P}_{\mathrm{s}}$ and impulse $\bar{I}_{\mathrm{s}}$ at the receptor location are then estimated - Figures 7.6 and 7.8 of CCPS, 2010 and the final side-on pressure $\left(\mathrm{P}_{\mathrm{S}}\right)$ and impulse $\left(\mathrm{I}_{\mathrm{S}}\right)$ are calculated:

$$
\begin{aligned}
& \mathrm{P}_{\mathrm{S}}=\mathrm{k}_{\mathrm{p}} * \bar{P}_{\mathrm{s}}^{*} \mathrm{p}_{0} \\
& \mathrm{I}_{\mathrm{S}}=\mathrm{k}_{\mathrm{i}}^{*} \bar{I}_{\mathrm{s}}^{*} \mathrm{p}_{0}{ }^{2 / 3} * \mathrm{E}_{\mathrm{ex}, \mathrm{a}} 1 / 3 / \mathrm{a}_{0}
\end{aligned}
$$

Where:

$\mathrm{a}_{0}=$ speed of sound in ambient air

$\mathrm{k}_{(\mathrm{p}, \mathrm{i})}$ scaling factor for cylindrical vessels, from Lees’, 2012 - Table 17.54

\begin{tabular}{|c|c|c|c|}
\hline Scaled dist. $\bar{R}$ & $\bar{R}<\mathbf{0 . 3}$ & $\bar{R}<\mathbf{3 . 5}$ & $\bar{R}>\mathbf{3 . 5}$ \\
\hline $\mathbf{k}_{\mathbf{P}}$ & 4 & 1.6 & 1.4 \\
\hline
\end{tabular}

\begin{tabular}{|c|c|c|c|}
\hline Scaled dist. $\bar{R}$ & $\bar{R}<\mathbf{0 . 3}$ & $\bar{R}<\mathbf{1 . 6}$ & $\bar{R}>\mathbf{1 . 6}$ \\
\hline $\mathbf{k}_{\mathbf{I}}$ & 4 & 1.6 & 1.4 \\
\hline
\end{tabular}


Missile impacts (Hydrotreater): For missiles or rocketing fragments from a bursting vessel, CCPS, 2010 provides a simplified approach (Baum) to estimate the maximum likely range for fragments, $R_{\text {frag. }}$ This approach is judged to be very conservative with respect to the potential for fragment travel for hydrotreater components:

1) The approach is derived from "open” field events (impacts of fragments with the enclosure and PDL-West building would significantly reduce the distance travelled),

2) The approach ignores drag associated with the fragments, and

3) The approach was derived for "thin-walled" vessels where the energy potential to weight ratio is much larger than that for the hydrotreater/distillation column components.

From CCPS, 2010 the maximum likely range for of the fragments, $\mathrm{R}_{\mathrm{frag}}$, meters is estimated by:

For vessels $<5 \mathrm{~m}^{3}$ the maximum likely range $\mathrm{R}_{\mathrm{frag}}=90 * \mathrm{~m}^{0.333}$

Where:

$\mathrm{m}=$ mass of the liquid and vapor in the vessel at the time of failure, $\mathrm{kg}$

Missile impacts (Distillation Column): For missiles or rocketing fragments from the Distillation Column, a different approach was used to estimate the maximum likely range for fragments, $\mathrm{R}_{\text {frag. }}$ This approach was used to account for the two different sections of the vessel with varying wall thickness. This approach is judged to be very conservative with respect to the potential for fragment travel for distillation column components:

1) The approach is derived from "open” field events (impacts of fragments with the enclosure and PDL-West building would significantly reduce the distance travelled) and

2) The approach ignores drag associated with the fragments.

From CCPS, 2000 the interpolated likely range for of the fragments, $\mathrm{R}_{\text {frag, }}$, meters is estimated by:

$$
\mathrm{R}_{\text {frag }}=\left(\bar{R} * \mathrm{~m}_{\text {frag }}\right) /\left(\rho_{0} * \mathrm{C}_{\mathrm{D}} * \mathrm{~A}_{\mathrm{D}}\right)
$$

Where:

$\bar{R}=$ scaled maximal range (dimensionless)

$\mathrm{m}_{\text {frag }}=$ mass of the fragment, $\mathrm{lb}$

$\rho_{0}=$ density of air, $\mathrm{lb}_{\mathrm{m}} / \mathrm{ft}^{3}$

$C_{D}=$ drag coefficient for fragment; for sphere $=0.47$

$A_{D}=$ fragment surface area, $\mathrm{ft}^{2}$

$\mathrm{g}=$ acceleration due to gravity, length/time ${ }^{2}$

Where:

$\overline{\mathrm{u}}=\rho_{0} \mathrm{C}_{\mathrm{D}} \mathrm{A}_{\mathrm{D}} \mathrm{u} 2 /\left(\mathrm{m}_{\mathrm{frag}} * \mathrm{~g}\right)$

$\mathrm{m}_{\text {frag }}=\mathrm{m}_{\text {vessel }} / \mathrm{n}_{\text {frag }}$

$A_{D}=A_{\text {vessel }} / n_{\text {frag }}$ 
Thermal Hazards: Thermal hazards, including radiation impacts, would be limited as the hazard scenarios are enclosed within the process enclosure and PDL-West building versus an open field. As such the (maximum) fireball size and duration are calculated as a measure of the potential severity of the event with respect to close (engulfed) distances.

CCPS, 2010 provides an estimate of the fireball diameter, $\mathrm{D}_{\mathrm{c}}$ and duration, $\mathrm{t}_{\mathrm{c}}$ based on mass of fuel, $\mathrm{m}_{\mathrm{f}}$ in the vessel.

$$
\begin{aligned}
& \mathrm{D}_{\mathrm{c}}=5.8^{*} \mathrm{~m}_{\mathrm{f}}^{(1 / 3)} \\
& \mathrm{t}_{\mathrm{c}}=0.45^{*} \mathrm{~m}_{\mathrm{f}}^{(1 / 3)} \text { for } \mathrm{m}_{\mathrm{f}}<30,000 \mathrm{~kg}
\end{aligned}
$$

Where:

$$
\mathrm{m}_{\mathrm{f}}=\text { mass of the fuel in the fireball, } \mathrm{kg}
$$

\subsubsection{BLEVE Results}

\section{Hydrotreater Reactor (R-130)}

For the hydrotreater reactor, R-130, it is assumed the pressure in the vessel is at the PRV set point 3000 psig. This is a reasonably conservative assumption as this is a significantly higher pressure than the operating pressure ( 2000 psig) and there were no events identified which would cause rapid significant pressure increases. It was conservatively assumed that the reactor contained only water and catalyst, and that the 13 liters of water volume contained 6.5 liters of liquid (water), as normally only minimal liquid is expected in the reactor and the remainder of the vapor space is steam. Accounting for hydrogen and bio-oil within the reactor would lower their potential energy due to the thermodynamic properties compared to water.

\section{Input Assumptions:}

Pressure State 1

Temperature State 1

Pressure State 2

Temperature State 2

Volume of Reactor

Free volume (assume 50\% filled with catalyst)

Volume of Liquid (assume $50 \%$ of free volume)

Speed of sound in air, $\mathrm{a}_{0}$

$\begin{array}{lc}3000 \mathrm{psig} & 20.6 \mathrm{MPa} \\ 368^{\circ} \mathrm{C} \text {, saturation temperature } \\ 14 \mathrm{psi} & 0.1 \mathrm{MPa} \\ 99.6^{\circ} \mathrm{C} \text {, saturation temperature } \\ 26 \text { liters } & 0.026 \mathrm{~m}^{3} \\ 13 \text { liters } & 0.013 \mathrm{~m}^{3} \\ 6.5 \text { liters } & 0.0065 \mathrm{~m}^{3} \\ 340 \mathrm{~m} / \mathrm{s} & \end{array}$

3000 psig $\quad 20.6 \mathrm{MPa}$

$368^{\circ} \mathrm{C}$, saturation temperature

$99.6^{\circ} \mathrm{C}$, saturation temperature

26 liters $\quad 0.026 \mathrm{~m}^{3}$

13 liters $\quad 0.013 \mathrm{~m}^{3}$

$340 \mathrm{~m} / \mathrm{s}$ 
Thermodynamic properties -Water; http://webbook.nist.gov/chemistry/fluid/

\begin{tabular}{|c|c|c|c|c|c|c|c|c|}
\hline $\begin{array}{c}\text { Temperature } \\
\left({ }^{\circ} \mathrm{C}\right)\end{array}$ & $\begin{array}{c}\text { Pressure } \\
\text { (MPa) }\end{array}$ & $\begin{array}{c}\text { Specific } \\
\text { Volume, } v \\
\left(\mathbf{m}^{3} / \mathbf{k g}\right)\end{array}$ & $\begin{array}{l}\text { Internal } \\
\text { Energy, u } \\
\text { (kJ/kg) }\end{array}$ & $\begin{array}{c}\text { Entropy } \\
\text { S } \\
\left(\mathrm{J} / \mathbf{g}^{*} \mathrm{~K}\right)\end{array}$ & $\begin{array}{c}\mathbf{C v} \\
\left(\mathbf{J} / \mathbf{g}^{*} \mathbf{K}\right)\end{array}$ & $\underset{\left(J / g^{*} K\right)}{\mathbf{C p}}$ & $\begin{array}{l}\text { Sound } \\
\text { Spd. } \\
(\mathbf{m} / \mathbf{s})\end{array}$ & Phase \\
\hline 99.606 & 0.1 & 0.0010432 & 417.4 & 1.3028 & 3.7702 & 4.2152 & 1543.5 & liquid \\
\hline 99.606 & 0.1 & 1.6939 & 2505.6 & 7.3588 & 1.5548 & 2.0784 & 471.99 & vapor \\
\hline 368.22 & 20.6 & 0.0021291 & 1817.5 & 4.067 & 3.6749 & 31.326 & 383.96 & liquid \\
\hline 368.22 & 20.6 & 0.005359 & 2261.5 & 4.8629 & 4.4004 & 65.397 & 373.25 & vapor \\
\hline
\end{tabular}

Using the input assumptions and thermodynamic data provided:

The positive side-on overpressure $\left(\mathrm{P}_{\mathrm{s}}\right)$ and positive side-on impulse $\left(\mathrm{I}_{\mathrm{s}}\right)$ at the following receptor locations are:

\begin{tabular}{|l|c|c|c|c|c|}
\hline $\begin{array}{r}\text { Actual Receptor } \\
\text { Distance, meters }\end{array}$ & 3 & $\mathbf{7}$ & $\mathbf{1 0}$ & 30 & 35 \\
\hline scaled distance $\bar{R}, \mathrm{~m}$ & $\mathbf{1 . 6 - 1 . 2}$ & $\mathbf{3 . 8}-\mathbf{2 . 7}$ & $\mathbf{5 . 4 - 3 . 9}$ & $\mathbf{1 6 . 3 - 1 1 . 7}$ & $\mathbf{1 9 - 1 3 . 7}$ \\
\hline $\mathrm{P}_{\mathrm{s}}, \mathrm{kPa}$ & $\mathbf{4 5 - 7 0}$ & $\mathbf{1 2 - 2 8}$ & $\mathbf{8 - 1 2}$ & $\mathbf{2}-\mathbf{3}$ & $\mathbf{1 . 4 - 2 . 5}$ \\
\hline $\mathrm{I}_{\mathrm{S}}, \mathrm{Pa}-\mathrm{S}$ & $\mathbf{0 . 0 9}-\mathbf{0 . 1 6}$ & $\mathbf{0 . 0 3 - 0 . 0 6}$ & $\mathbf{0 . 0 2}-\mathbf{0 . 0 3}$ & $<\mathbf{0 . 0 1 - 0 . 0 1}$ & $<\mathbf{0 . 0 1}$ \\
\hline
\end{tabular}

The maximum likely range of fragments calculated using the CCPS, 2010 method was determined to be $\sim 145$ meters. As noted in Section 3.4.1.1 this distance is judged to be a very conservative estimate.

Thermal hazards were not assessed as the evaluation assumed the vessel was filled with water (liquid and vapor) to maximize the pressure and fragment impacts. Thermal hazards would be constrained by the PDL-West building and would be expected to be minimal given the steam (inerting and heat absorption) and limited quantity of flammable material. Thermal hazards are addressed in the following discussion for the distillation column and in Section 3.4.2 PVB for the reactor (assuming only hydrogen) in the vapor space.

\section{Distillation Column (V-184)}

For the Distillation Column, V-184, it is assumed the pressure in the vessel is at the PRV set point of 70 psig. This is a reasonably conservative assumption as this is a significantly higher pressure than the typical operating pressure (atmospheric to 15 psig) and there were no events identified which would cause rapid significant pressure increases. V-184 consists of two pipe sections of differing wall thickness; the smaller wall thickness (0.203 inches) was used in calculations as a conservative estimate. Due to the differing size of the sections, it was assumed that two fragments would result in the event of a BLEVE. It was conservatively assumed that the distillation column was filled $~ 70 \%$ (11 liters) with octane and the remaining vapor space (5.3 liters) consisting of saturated octane vapors. Accounting for treated bio-oil or heavy distillates within the distillation column would lower the potential energy of the process due to their thermodynamic properties compared to octane. 
Input Assumptions:

Pressure State 1

Temperature State 1

Pressure State 2

Temperature State 2

Volume of V-184

Volume of Liquid, octane, $70 \%$

Speed of sound in air, $\mathrm{a}_{0}$

Equivalent spherical diameter

Vessel failure pressure

Vessel liquid fill fraction

Vessel wall thickness

Vessel wall density

Temperature

Ambient pressure

Drag coefficient of fragment

Lift to drag ratio:
70 psig $\quad 0.48 \mathrm{MPa}$

$193^{\circ} \mathrm{C}$ saturation temperature

$14 \mathrm{psi} \quad 0.1 \mathrm{MPa}$

$126^{\circ} \mathrm{C}$ saturation temperature

16.3 liters $\quad 0.0163 \mathrm{~m}^{3}$

11 liters $\quad 0.011 \mathrm{~m}^{3}$

$340 \mathrm{~m} / \mathrm{s}$

$0.3145 \mathrm{~m}$

70 psig $\quad 482.63 \mathrm{kPa}$ abs

0.675

0.203 in $\quad 0.52 \mathrm{~cm}$

$7800 \mathrm{~kg} / \mathrm{m}^{3}$

$193^{\circ} \mathrm{C} \quad 466.15 \mathrm{~K}$

$101.325 \mathrm{kPa}$ abs

0.47

0

Thermodynamic properties -Octane; http://webbook.nist.gov/chemistry/fluid/

\begin{tabular}{|c|c|c|c|c|c|c|c|c|}
\hline $\begin{array}{l}\text { Temperature } \\
\text { (C) }\end{array}$ & $\begin{array}{l}\text { Pressure } \\
\text { (MPa) }\end{array}$ & $\begin{array}{c}\text { Specific } \\
\text { Volume, } \\
v(\mathrm{~m} 3 / \mathrm{kg})\end{array}$ & $\begin{array}{c}\text { Internal } \\
\text { Energy, u } \\
(\mathbf{k J} / \mathbf{k g})\end{array}$ & $\begin{array}{c}\text { Entropy } \\
\mathbf{S} \\
\left(\mathrm{J} / \mathbf{g}^{*} \mathrm{~K}\right) \\
\end{array}$ & $\underset{\left(\mathbf{J} / \mathbf{g}^{*} \mathbf{K}\right)}{\mathbf{C v}}$ & $\underset{\left(J / g^{*} K\right)}{\mathbf{C p}}$ & $\begin{array}{l}\text { Sound } \\
\text { Spd. } \\
(\mathbf{m} / \mathbf{s})\end{array}$ & Phase \\
\hline 125.51 & 0.101 & 0.0016331 & -0.47239 & -0.00076975 & 2.1864 & 2.6481 & 772.03 & liquid \\
\hline 125.51 & 0.101 & 0.27138 & 274.56 & 0.75746 & 2.0434 & 2.1426 & 164.49 & vapor \\
\hline 192.93 & 0.48253 & 0.0018453 & 188.72 & 0.43715 & 2.4468 & 2.9968 & 525.54 & liquid \\
\hline 192.93 & 0.48253 & 0.058767 & 409.58 & 0.96994 & 2.3665 & 2.5465 & 156.9 & vapor \\
\hline
\end{tabular}

Using the input assumptions and thermodynamic data provided:

The positive side-on overpressure $\left(\mathrm{P}_{\mathrm{s}}\right)$ and positive side-on impulse $\left(\mathrm{I}_{\mathrm{s}}\right)$ at the following receptor locations are:

\begin{tabular}{|l|c|c|c|c|c|}
\hline $\begin{array}{r}\text { Actual Receptor } \\
\text { Distance, meters }\end{array}$ & $\mathbf{3}$ & $\mathbf{7}$ & $\mathbf{1 0}$ & $\mathbf{3 0}$ & 35 \\
\hline scaled distance $\bar{R}, \mathrm{~m}$ & $\mathbf{3 . 6}-\mathbf{2 . 6}$ & $\mathbf{8 . 5}-\mathbf{6 . 1}$ & $\mathbf{1 2 - 8 . 7}$ & $\mathbf{3 6}-\mathbf{2 6}$ & $\mathbf{4 2}-\mathbf{3 0}$ \\
\hline $\mathrm{P}_{\mathrm{S}}, \mathrm{kPa}$ & $\mathbf{1 3 - 2 9}$ & $\mathbf{4 . 3}-\mathbf{7}$ & $\mathbf{3}-\mathbf{4}$ & $<\mathbf{1 . 3}-\mathbf{1 . 4}$ & $<\mathbf{1 . 3}$ \\
\hline $\mathrm{I}_{\mathrm{S}}, \mathrm{Pa}-\mathrm{S}$ & $\mathbf{0 . 0 1 7 - 0 . 0 4}$ & $\mathbf{0 . 0 0 7}-\mathbf{0 . 0 1}$ & $\mathbf{0 . 0 0 5}-\mathbf{0 . 0 0 9}$ & $<\mathbf{0 . 0 0 4}$ & $<\mathbf{0 . 0 0 4}$ \\
\hline
\end{tabular}

The interpolated likely range of fragments calculated using the CCPS, 2000 method was determined to be $\sim 84$ meters. As noted in Section 3.4.1.1 this distance is judged to be a very conservative estimate. 
The maximum fireball size was determined to be 10.6 meters with a duration of 0.8 seconds, not accounting for confinement provided by the enclosure or building.

\subsubsection{Pressure Vessel Burst Scenarios}

The hazard analysis identified scenarios as resulting in pressure vessel bursts (PVBs) in the Reactor and Distillation Columns and Process Vessels.

Of these events, consequences for the Hydrotreater Reactor (R-130) and Distillation Feed Tank (V-180) are further presented here. These vessels are pose the highest consequences based on pressure and vessel volume.

\subsubsection{PVB Consequence Methodology}

Similar to a BLEVE, a PVB accident is the result of the sudden catastrophic failure of a pressurized vessel containing gas. Depending on whether the gas in the vessel is flammable of non-flammable a PVB may include the following effects:

- blast effects (pressure wave due to the rapid expansion of the gas)

- missile impacts (fragment and debris throw)

- fireball (thermal hazards)

CCPS, 2010 notes PVBs usually do not result in ignition; therefore, thermal hazards are only addressed for the R-130 reactor under the assumption that the vessel free volume (headspace) is completely filled with hydrogen.

For analyzing PVBs, the Brode constant volume energy addition methodology, which provides an upper limit of the energy released, according to CCPS, 2010, was followed.

Blast Effects: The explosion energy can be written as:

Explosion Energy, $\mathrm{E}_{\mathrm{ex}, \mathrm{Br}}=\left(\mathrm{p}_{1}-\mathrm{p}_{0}\right) \mathrm{V} 1 /\left(\dot{Y}_{1}-1\right)$

Where:

$\dot{Y}_{1}=$ ratio of constant pressure to constant volume of specific heat of the gas in the vessel

$\mathrm{p}_{0}=$ ambient (atmospheric) pressure to constant volume of specific heat of the gas in the vessel

$\mathrm{p}_{1}=$ pressure in the vessel prior to burst

$\mathrm{V}_{1}=$ Volume of vessel (gas)

Energy available - assuming ductile failure $\mathrm{E}_{\mathrm{ex}, \mathrm{a}}=0.4^{*} \mathrm{E}_{\mathrm{ex}, \mathrm{Br}}$

The scaled standoff distance, $\bar{R}$ of the receptor is then estimated:

$$
\bar{R}=\mathrm{R}\left[\mathrm{p}_{0} / \mathrm{E}_{\mathrm{ex}, \mathrm{a}}\right]^{1 / 3}
$$

Where:

$$
\begin{aligned}
& \mathrm{R}=\text { distance to receptor } \\
& \mathrm{p}_{0}=\text { atmospheric pressure }
\end{aligned}
$$


The scaled pressure $\bar{P}_{\mathrm{s}}$ and impulse $\bar{I}_{\mathrm{s}}$ at the receptor location are then determined - Figures 7.6 and 7.8 of CCPS, 2010 and the final side-on pressure $\left(P_{S}\right)$ and impulse $\left(I_{S}\right)$ are calculated:

$$
\begin{aligned}
& \mathrm{P}_{\mathrm{S}}=\mathrm{k}_{\mathrm{p}} * \bar{P}_{\mathrm{s}}^{*} \mathrm{p}_{0} \\
& \mathrm{I}_{\mathrm{S}}=\mathrm{k}_{\mathrm{i}} * \bar{I}_{\mathrm{s}}^{*} \mathrm{p}_{0}{ }^{2 / 3} * \mathrm{E}_{\mathrm{ex}, \mathrm{a}}{ }^{1 / 3} / \mathrm{a}_{0}
\end{aligned}
$$

Where:

$\mathrm{a}_{0}=$ speed of sound in ambient air

$\mathrm{k}_{(\mathrm{p}, \mathrm{i})}$ scaling factor for cylindrical vessels, Lees’, 2012, Table 17.54

\begin{tabular}{|c|c|c|c|}
\hline Scaled dist. $\bar{R}$ & $\bar{R}<\mathbf{0 . 3}$ & $\bar{R}<\mathbf{3 . 5}$ & $\bar{R}>\mathbf{3 . 5}$ \\
\hline $\mathbf{k}_{\mathbf{P}}$ & 4 & 1.6 & 1.4 \\
\hline
\end{tabular}

\begin{tabular}{|c|c|c|c|}
\hline Scaled dist. $\bar{R}$ & $\bar{R}<\mathbf{0 . 3}$ & $\bar{R}<\mathbf{1 . 6}$ & $\bar{R}>\mathbf{1 . 6}$ \\
\hline $\mathbf{k}_{\mathbf{I}}$ & 4 & 1.6 & 1.4 \\
\hline
\end{tabular}

Missile impacts (rocketing fragments): For missiles or rocketing fragments from a bursting vessel, the same approach as discussed for BLEVEs was used.

Thermal Hazards: For thermal hazards from a bursting vessel, the same approach as discussed for BLEVEs was used.

\subsubsection{PVB Results}

\section{Hydrotreater Reactor (R-130)}

For the hydrotreater reactor, R-130, it is assumed the pressure in the vessel is at the PRV set point 3000 psig. This is a reasonably conservative assumption as this is a significantly higher pressure than the typical operating pressure ( 2000 psig) and there were no events identified which would cause rapid significant pressure increases resulting in a common cause failure of the pressure relief valve. It was conservatively assumed that the reactor contained only hydrogen and catalyst.

Input Assumptions:

\begin{tabular}{lll}
\hline Pressure State 1 & $3000 \mathrm{psig}$ & $20.6 \mathrm{MPa}$ \\
Pressure State 0 & $14 \mathrm{psi}$ & $0.1 \mathrm{MPa}$ \\
Volume of Reactor & 26 liters & $0.026 \mathrm{~m}^{3}$ \\
Free volume (assume 50\% filled with catalyst) & 13 liters & $0.013 \mathrm{~m}^{3}$ \\
Volume of hydrogen & 13 liters & $0.013 \mathrm{~m}^{3}$ \\
Specific Volume & $0.13651 \mathrm{~m}^{3} / \mathrm{kg}$ \\
$\dot{Y}_{1}$ & 1.41 \\
Speed of sound in air, a 0 & $340 \mathrm{~m} / \mathrm{s}$
\end{tabular}

Using the input assumptions and thermodynamic data provided:

The positive side-on overpressure $\left(\mathrm{P}_{\mathrm{s}}\right)$ and positive side-on impulse $\left(\mathrm{I}_{\mathrm{s}}\right)$ at the following receptor locations are: 
Hydrotreater/Distillation Column Hazard Analysis Report

\begin{tabular}{|l|c|c|c|c|c|}
\hline \multicolumn{1}{|c|}{$\begin{array}{c}\text { Actual Receptor Distance, } \\
\text { meters }\end{array}$} & $\mathbf{3}$ & $\mathbf{7}$ & $\mathbf{1 0}$ & $\mathbf{3 0}$ & 35 \\
\hline scaled distance $\bar{R}, \mathrm{~m}$ & $\mathbf{1 . 7}$ & $\mathbf{4 . 1}$ & $\mathbf{5 . 8}$ & $\mathbf{1 7}$ & $\mathbf{2 3}$ \\
\hline $\mathrm{P}_{\mathrm{s}}, \mathrm{kPa}$ & $\mathbf{4 6}$ & $\mathbf{1 1}$ & $\mathbf{7}$ & $\mathbf{1 . 7}$ & $<\mathbf{1 . 4}$ \\
\hline $\mathrm{I}_{\mathrm{S}}, \mathrm{Pa}-\mathrm{S}$ & $\mathbf{0 . 0 8}$ & $\mathbf{0 . 0 2}$ & $\mathbf{0 . 0 1 5}$ & $\mathbf{0 . 0 0 5}$ & $<\mathbf{0 . 0 0 5}$ \\
\hline
\end{tabular}

The maximum likely range of fragments calculated using the CCPS, 2010 method was determined to be $\sim 41$ meters. As noted in Section 3.4.1.1 this distance is judged to be a very conservative estimate.

The maximum fireball size was determined to be 2.6 meters with a duration of 0.2 seconds.

Distillation Feed Tank (V-180)

For the Distillation Feed Tank, V-180, it is assumed the pressure in the vessel is at the PRV set point of 70 psig. This is a reasonably conservative assumption as this is a significantly higher pressure than the typical operating pressure (atmospheric to 15 psig) and there were no events identified which would cause rapid significant pressure increases resulting in a common cause failure of the pressure relief valve. It was conservatively assumed that the vessel contained only nitrogen.

Input Assumptions:

Pressure State 1

Pressure State 0

Volume of vessel

Specific Volume $\left(20^{\circ} \mathrm{C}\right)$

$\dot{Y}_{1}$

Speed of sound in air, $\mathrm{a}_{0}$

70 psig $\quad 0.48 \mathrm{MPa}$

14 psig $\quad 0.1 \mathrm{MPa}$

140 liters $\quad 0.140 \mathrm{~m}^{3}$

$0.18107 \mathrm{~m}^{3} / \mathrm{kg}$

1.4

$340 \mathrm{~m} / \mathrm{s}$

Using the input assumptions and thermodynamic data provided:

The positive side-on overpressure $\left(\mathrm{P}_{\mathrm{s}}\right)$ and positive side-on impulse $\left(\mathrm{I}_{\mathrm{s}}\right)$ at the following receptor locations are:

\begin{tabular}{|l|c|c|c|c|c|}
\hline \multicolumn{1}{|c|}{$\begin{array}{c}\text { Actual Receptor Distance, } \\
\text { meters }\end{array}$} & $\mathbf{3}$ & $\mathbf{7}$ & $\mathbf{1 0}$ & $\mathbf{3 0}$ & $\mathbf{3 5}$ \\
\hline scaled distance $\bar{R}, \mathrm{~m}$ & $\mathbf{2 . 9 5}$ & $\mathbf{6 . 8 8}$ & $\mathbf{9 . 8 3}$ & $\mathbf{2 9 . 4 8}$ & $\mathbf{3 4 . 4 0}$ \\
\hline $\mathrm{P}_{\mathrm{s}}, \mathrm{kPa}$ & $\mathbf{2 0 . 3}$ & $\mathbf{5 . 5}$ & $\mathbf{3 . 7}$ & $<\mathbf{1 . 4 2}$ & $<\mathbf{1 . 4 2}$ \\
\hline $\mathrm{I}_{\mathrm{S}}, \mathrm{Pa}-\mathrm{S}$ & $\mathbf{0 . 0 2}$ & $\mathbf{0 . 0 0 8}$ & $\mathbf{0 . 0 0 5}$ & $<\mathbf{0 . 0 0 0 4}$ & $<\mathbf{0 . 0 0 0 4}$ \\
\hline
\end{tabular}

The maximum likely range of fragments was determined to be $~ 83$ meters. As noted in Section 3.4.1.1 this distance is judged to be a very conservative estimate.

\subsubsection{Deflagration Scenarios}

The hazard analysis identified scenarios as resulting in flammable gas/vapors being released to the enclosure from the hydrogen system and process vessels and piping.

Of these events, consequences from a rupture of the hydrogen supply piping within the hydrotreater enclosure was analyzed as a bounding case. The consequences for a large release of hydrogen gas 
(assumed not to be a PVB or BLEVE) from the hydrotreater reactor was also analyzed to provide a bounding case for the release of vapors from process vessels and piping.

\subsubsection{Deflagration Consequence Methodology}

Potential ignition of flammable vapors within the enclosure were modeled using the TNT Equivalency Method as evaluated in the Physical Sciences Facility Fire Hazards Analysis Report, following the approach presented in Analytical Approach for Gas Explosions for DOE Nuclear and Non-Nuclear Facilities (Louie and Restrepo).

The TNT approach provides a proportional relationship between the total quantity of flammable material released (whether or not it is within the flammability limits or at the stoichiometric concentration) to an equivalent weight of TNT. This weight of TNT, $W_{\text {TNT, }}$ is then used to determine a scaled distance, $\bar{R}$, from which predicted overpressure can used determined using the peak side-on overpressure curve appropriate for the surface TNT equivalence method:

$$
\mathrm{W}_{\mathrm{TNT}}=\eta_{\mathrm{g}}\left(\mathrm{W}_{\mathrm{g}} * \mathrm{H}_{\mathrm{g}} / \mathrm{H}_{\mathrm{TNT}}\right)
$$

Where:

$$
\begin{aligned}
& \eta_{\mathrm{g}}=\text { TNT equivalence factor or yield factor (dimensionless) } \\
& \mathrm{W}_{\mathrm{g}}=\text { weight of the combustible gas }(\mathrm{kg}) \\
& \mathrm{H}_{\mathrm{g}}=\text { combustion energy of the combustible gas }(\mathrm{J} / \mathrm{kg}) \\
& \mathrm{H}_{\mathrm{TNT}}=\text { TNT blast energy }(\mathrm{J} / \mathrm{kg})
\end{aligned}
$$

The scaled distance, $\overline{\mathrm{R}}$ is then calculated by:

$$
\overline{\mathrm{R}}=\mathrm{R} / \mathrm{W}^{1 / 3} \mathrm{TNT}
$$

Where:

$$
\mathrm{R}=\text { distance to receptor }
$$

For TNT equivalency methods, the side-on pressure can then be taken directly from the appropriate overpressure curve.

\subsubsection{Deflagration Results}

\section{Hydrogen Supply Line Rupture}

For the hydrogen supply line rupture, it was assumed the quantity of hydrogen released equated to the volume of the hydrotreater enclosure.

Input Assumptions and thermodynamic data:

\begin{tabular}{ll}
\hline Volume of hydrogen in the enclosure & $285 \mathrm{~m}^{3}$ \\
Density of Hydrogen at 20C & $0.083191 \mathrm{~kg} / \mathrm{m}^{3}$ \\
Weight of Hydrogen & $23.7 \mathrm{~kg}$ \\
TNT equivalence factor $\eta_{\mathrm{g}}$ & $0.2 \mathrm{from}$ (Louie and Restrepo) \\
Combustion energy, $\mathrm{H}_{\mathrm{g}}$ & $4.6 \mathrm{E}+06 \mathrm{~J} / \mathrm{kg}$ \\
TNT blast energy, $\mathrm{H}_{\mathrm{TNT}}$ & $1.42 \mathrm{E}+06 \mathrm{~J} / \mathrm{kg}$
\end{tabular}


From the TNT equivalence method:

$$
\begin{aligned}
\mathrm{W}_{\mathrm{TNT}} & =\eta_{\mathrm{g} *}\left(\mathrm{~W}_{\mathrm{g}} * \mathrm{H}_{\mathrm{g}} / \mathrm{H}_{\mathrm{TNT}}\right) \\
& =1.5 \mathrm{E}-01 \mathrm{~kg}
\end{aligned}
$$

The positive side-on overpressure $\left(\mathrm{P}_{\mathrm{s}}\right)$ at the following receptor locations was then determined based on the scaled distance (Louie and Restrepo):

\begin{tabular}{|l|c|c|c|c|c|}
\hline $\begin{array}{r}\text { Actual Receptor Distance, } \\
\text { meters }\end{array}$ & 3 & 7 & $\mathbf{1 0}$ & 30 & 35 \\
\hline scaled distance $\bar{R}, \mathrm{~m}$ & $\mathbf{5 . 6}$ & $\mathbf{1 3}$ & $\mathbf{1 9}$ & $\mathbf{5 6}$ & $\mathbf{6 5}$ \\
\hline $\mathrm{P}_{\mathrm{s}}, \mathrm{bar}$ & $\mathbf{0 . 4 0}$ & $\mathbf{0 . 1 5}$ & $\mathbf{0 . 0 7}$ & $\mathbf{0 . 0 2}$ & $\mathbf{0 . 0 1 4}$ \\
\hline $\mathrm{P}_{\mathrm{s}}, \mathrm{kPa}$ & $\mathbf{4 0}$ & $\mathbf{1 5}$ & $\mathbf{7}$ & $\mathbf{2}$ & $\mathbf{1 . 4}$ \\
\hline
\end{tabular}

\section{Hydrotreater Reactor (R-130)}

For the hydrotreater reactor, R-130, it is assumed the mass in the vessel was based on the vessel free volume and the pressure at the pressure relief valve setpoint of 3000 psig with a temperature of $368^{\circ} \mathrm{C}$ as was evaluated in the BLEVE case. This is a conservative assumption with respect to normal operating pressure ( 2000 psig). To account for hydrogen within the supply line, the weight of hydrogen released was doubled. 
Input Assumptions and thermodynamic data:

Volume of hydrogen is Vessel

Specific volume of Hydrogen $v_{1}$

Weight of Hydrogen $\left(\mathrm{V} / \mathrm{v}_{1}\right)$

TNT equivalence factor $\eta_{\mathrm{g}}$

Combustion energy, $\mathrm{H}_{\mathrm{g}}$

TNT blast energy, $\mathrm{H}_{\text {TNT }}$
$0.013 \mathrm{~m}^{3}$

$0.13651 \mathrm{~m}^{3} / \mathrm{kg}$

$0.095231 \mathrm{~kg}$

0.2 from (Louie and Restrepo)

$4.6 \mathrm{E}+06 \mathrm{~J} / \mathrm{kg}$

$1.42 \mathrm{E}+06 \mathrm{~J} / \mathrm{kg}$

From the TNT equivalence method:

$$
\begin{aligned}
\mathrm{W}_{\mathrm{TNT}} & =\eta_{\mathrm{g}}\left(\mathrm{W}_{\mathrm{g}} * \mathrm{H}_{\mathrm{g}} / \mathrm{H}_{\mathrm{TNT}}\right) \\
& =1.23 \mathrm{E}-03 \mathrm{~kg}
\end{aligned}
$$

The positive side-on overpressure $\left(\mathrm{P}_{\mathrm{s}}\right)$ at the following receptor locations was then determined based on the scaled distance (Louie and Restrepo):

\begin{tabular}{|l|c|c|c|}
\hline $\begin{array}{r}\text { Actual Receptor Distance, } \\
\text { meters }\end{array}$ & $\mathbf{3}$ & $\mathbf{7}$ & $\mathbf{1 0}$ \\
\hline scaled distance $\bar{R}, \mathrm{~m}$ & $\mathbf{2 8}$ & $\mathbf{6 5}$ & $\mathbf{9 3}$ \\
\hline $\mathrm{P}_{\mathrm{s}}, \mathrm{bar}$ & $\mathbf{. 0 2 5}$ & $\mathbf{0 . 0 1}$ & $<\mathbf{0 . 0 1}$ \\
\hline $\mathrm{P}_{\mathrm{s}}, \mathrm{kPa}$ & $\mathbf{2 . 5}$ & $\mathbf{1}$ & $<\mathbf{1}$ \\
\hline
\end{tabular}

\subsubsection{Calculation Summary}

Comparing the calculated overpressures from the above conservative analyses to the damage estimates of Table 3-5 shows that a failure of the hydrotreater/distillation column enclosure would result in the event of a BLEVE, PVB, or explosion of hydrogen within the enclosure. However, only for a BLEVE of the reactor (R-130) could significant overpressures (greater than $21 \mathrm{kPa}$ ) be developed which would challenge the PDL-West building structure itself. There were no cases in which overpressures sufficient to result in greater than minor damage $(7 \mathrm{kPa})$ reached at the nearest analyzed location (PDL-East).

For missile generation, the CCPS, 2010 methodology conservatively estimates missile ranges out to $\sim 145$ meters for the hydrotreater. As noted, this ignores several physical properties associated with the event. DOE-TIC 11268, Figure 6.17 identifies that the 90th percentile fragment range as being less than 24 meters ( 80 feet) for an energy level of 2.2E+07 joules (1.6E+07 foot-pounds) which is more than 10 times greater than calculated energy available for the R-130 BLEVE limiting case.

For all events analyzed, the robust design of the hydrotreater/distillation column systems make the overpressure and missile generation events very low likelihood scenarios. 
Table 3-5. Damage Estimates for Common Structures Based on Overpressure

\begin{tabular}{|c|c|l|}
\hline \multicolumn{2}{|c|}{ Pressure } & \multirow{2}{*}{ Damage } \\
\hline 2.07 & 0.3 & $\begin{array}{l}\text { "Safe distance" (probability 0.95 of no serious damage below this } \\
\text { value); projectile limit; some damage to house ceilings; 10\% } \\
\text { window glass broken. }\end{array}$ \\
\hline $3.4-6.9$ & $0.5-1$ & $\begin{array}{l}\text { Large and small windows usually shattered; occasional damage to } \\
\text { window frames. }\end{array}$ \\
\hline $13.8-20.7$ & $2-3$ & Concrete or cinder block walls, not reinforced, shattered \\
\hline $20.7^{(1)}-27.7$ & $3-4$ & $\begin{array}{l}\text { Frameless, self-framing steel panel building demolished; rupture of } \\
\text { oil storage tanks }\end{array}$ \\
\hline 34.5 & 5 & $\begin{array}{l}\text { Wooden utility poles snapped; tall hydraulic press (40,000 lb) in } \\
\text { building slightly damaged }\end{array}$ \\
\hline $34.5-48.2$ & $5-7$ & Nearly complete destruction of houses \\
\hline 68.9 & 10 & $\begin{array}{l}\text { Probable total destruction of buildings; heavy machine tools } \\
\text { (7000 lb) moved and badly damaged; very heavy machine tools } \\
\text { (12000 lb) survive }\end{array}$ \\
\hline
\end{tabular}

AIChE/CCPS, Guidelines for Chemical Process Quantitative Risk Analysis, New York: AIChE, 2000

(1) Assumed threshold for serious damage from Lees’ 2012.

“Table 17.28- Typical Values of Failure Pressures in Building Structures

\begin{tabular}{|l|l|}
\hline & Failure Pressure $(\mathrm{kN} / \mathrm{m} 2)[\mathrm{kPa}]$ \\
\hline Windows (normal) & $3-4.6$ \\
\hline Windows (strained) & 1 , or even 0.2 \\
\hline Chipboard $(19 \mathrm{~mm})$ & 7 \\
\hline Brick wall $(114 \mathrm{~mm})$ & Survived at 23, destroyed at 35 \\
\hline Brick wall $(228 \mathrm{~mm})$ & Survived at70, destroyed at 105 \\
\hline
\end{tabular}

It has been suggested by Buckland (1980) that the explosion pressure should not exceed $21 \mathrm{kN} / \mathrm{m}^{2}$ if the building is to avoid serious damage.” 


\subsection{HAZARD CONTROLS}

\subsection{Critical Controls}

This section describes the attributes of the critical controls (Table 4-1) specifically identified in the hazard analysis as mitigating against the higher consequence hazards associated with the hydrotreater/distillation column process as addressed in Section 3.4.

Table 4-1 Critical Hazard Controls

\begin{tabular}{|c|c|c|}
\hline Hazard Control & Event Type & Hazard ID \\
\hline \multirow[t]{3}{*}{$\begin{array}{l}\text { Vessel Design per ASME Section VIII } \\
\text { and ASME B341.3 }\end{array}$} & BLEVE & $\begin{array}{l}\text { H.4-6; H.4-7; H.4-9; H.7-1; H.2-10; H.4-11; } \\
\text { H.4-18; H.1-19; H.2-20; D.2-7; D.4-3; } \\
\text { D.4-4; D.4-5; U-9 }\end{array}$ \\
\hline & PVB & $\begin{array}{l}\text { H.1-16; H.2-7; H.4-17; H.4-18; H.4-22; } \\
\text { H.4-29; H.4-31; H.7-4; D.1-6; D.1-7; } \\
\text { D.4-13 }\end{array}$ \\
\hline & FA & $\begin{array}{l}\text { H.4-8; H.4-15; H.4-20; H.7-8; D.1-10; } \\
\text { D.2-3; D.4-11; D.4-9; }\end{array}$ \\
\hline \multirow[t]{3}{*}{$\begin{array}{l}\text { Relief Valve Sizing and Flowpath } \\
\text { Design }\end{array}$} & BLEVE & $\begin{array}{l}\text { H.1-19; H.2-10; H.4-6; H.4-7; H.7-1;D.2-7; } \\
\text { D.4-3; }\end{array}$ \\
\hline & PVB & $\begin{array}{l}\text { H.1-11; H.1-15; H.1-16; H.1-21; H.2-7; } \\
\text { H.2-10; H.4-1; H.4-17; H.4-22; H.4-29; } \\
\text { H.4-31; H.7-4; D.1-6; D.1-7; D.1-14; } \\
\text { D.4-13 }\end{array}$ \\
\hline & FA & D.1-10; U-8 \\
\hline Piping Design per B31.3 and NFPA 55 & FA & H.5-2; H.6-1; H.7-7; D.1-10 \\
\hline \multirow{2}{*}{$\begin{array}{l}\text { Hydrogen Piping and Excess Flow } \\
\text { Valve Design per IFC }\end{array}$} & BLEVE & H.4-10; U-10 \\
\hline & FA & $\mathrm{U}-25$ \\
\hline $\begin{array}{l}\text { Reactor and Distillation Column High- } \\
\text { High Temperature Interlock }\end{array}$ & BLEVE & H.2-20; H.3-6; D.2-17 \\
\hline \multirow{2}{*}{$\begin{array}{l}\text { Enclosure Design as Class } 1 \text { Division } 2 \\
\text { environment }\end{array}$} & BLEVE & D.4-5 \\
\hline & FA & $\begin{array}{l}\text { H.1-8; H.1-12; H.1-14; H.4-23; H.4-26; } \\
\text { H.4-28; H.4-8; H.5-2; H.7-5; H.7-9; D.5-7 }\end{array}$ \\
\hline Enclosure Ventilation System Design & FA & $\begin{array}{l}\text { H.1-8; H.1-12; H.1-14; H.1-17; H.2-1; } \\
\text { H.2-2; H.2-3; H.4-23;H.4-28; H.4-8; H.7-5; } \\
\text { H.7-9; D.1-8; D.2-1; D.2-2; D.2-3; D.4-7; } \\
\text { D.4-9; D.5-7 }\end{array}$ \\
\hline Hydrogen Monitor & FA & $\begin{array}{l}\text { H.1-8; H.1-12; H.1-14; H.1-17; H.2-1; } \\
\text { H.2-2; H.2-3; H.4-8; H.4-26; D.1-8 }\end{array}$ \\
\hline Flammable Vapor Monitor & FA & $\begin{array}{l}\text { H.1-8; H.1-12; H.1-14; H.2-1; H.2-3; H.4-8; } \\
\text { D.2-3 }\end{array}$ \\
\hline \multirow[t]{3}{*}{ Pressure Test Procedure } & BLEVE & H.4-9; H.4-11; D.4-4 \\
\hline & PVB & H.4-18; D.4-13 \\
\hline & FA & $\begin{array}{l}\text { H.1-8; H.1-12; H.1-17; H.1-18; H.4-8; } \\
\text { H.4-15; H.4-20; H.4-28; H.7-8; D.1-8; } \\
\text { D.1-13; D.2-1; D.2-2; D.2-3; D.4-9; D.4-11 }\end{array}$ \\
\hline
\end{tabular}




\subsubsection{Vessel and Piping Design}

The robust design of vessels, components, and piping (tubing) ensures the pressure integrity of the process boundary for normal operations and upset conditions.

Vessel Design: The R-130 reactor vessel and V-184 distillation column are designed, fabricated, welded, inspected, and tested in accordance with ASME B31.3 and augmented consistent with the ASME Boiler and Pressure Vessel Code (ASME B\&PV Code), Section VIII.

All vessels with a diameter greater than 6 inches and a design pressure greater than 15 psi are designed, fabricated, welded, inspected, and tested in accordance with the ASME B\&PV Code, Section VIII.

Relief Valve Sizing: All relief valves and pressure relief flowpaths are sized for the worst-case flow rates, including any backflow from high to low pressure areas, per API 521. This includes the addition of vessel insulation on vessels where required to support flow rates (CTI 12-631).

PSE-2005 upstream of Check Valve CK-2012 protects against backflow through P-121A/B from the reactor.

Piping Design: All pressure piping is designed, installed (approved fittings, quick disconnects, appropriate support distances, etc.), and leak tested in accordance with ASME B31.3 and NFPA 55. The new valve, HV-2018, upstream of HV-2009 provides positive pressure boundary from the reactor R-130 when draining bio-oil/acetone from the P-121A/B pumps during the shutdown flushing modes.

Hydrogen Utility (supplied) Design: All hydrogen piping is installed in accordance with the International Fire Code (IFC), which includes an appropriately sized excess flow control valve. Maximum hydrogen pressure - limited by compressor (3000 psi) and protected by pressure relief valve. 
Table 4-2 Vessel and Piping Design Summary

\begin{tabular}{|c|c|c|c|c|}
\hline Component & $\begin{array}{c}\text { Vessel Design } \\
\text { Pressure }^{(1)(2)} \\
\text { psig }^{-}\end{array}$ & $\begin{array}{c}\text { Vessel Design } \\
\text { Temperature }{ }^{(3)} \\
{ }^{\circ} \mathrm{C}\end{array}$ & $\begin{array}{l}\text { Pressure Relief } \\
\text { Setpoint } \\
\text { Psig }{ }^{(1)}\end{array}$ & Insulation $^{(1)}$ \\
\hline $\mathrm{V}-120$ & 135 & 148 & 70 & Yes \\
\hline $\mathrm{V}-125$ & 155 & 148 & 100 & No \\
\hline R-130 & 3000 & $\begin{array}{l}426 \text { (heads) } \\
537 \text { (shell) }\end{array}$ & 3000 & No \\
\hline V-140 & 3000 & 454 & 3000 & No \\
\hline LG-142 & 3000 & & & \\
\hline LG-147 & 100 & 148 & $\mathrm{Atm}^{(4)}$ & NR \\
\hline V-160A/B & 155 & 148 & 70 & Yes \\
\hline V-161A/B & 155 & 148 & 70 & Yes \\
\hline V-162 & $180^{(4)}$ & 148 & $\operatorname{Atm}^{(5)}$ & NR \\
\hline V-163 & $180^{(4)}$ & 148 & $\operatorname{Atm}^{(5)}$ & NR \\
\hline V-180 & 135 & 148 & 70 & Yes \\
\hline V-184 & $100^{(5)}$ & 454 & 70 & Yes \\
\hline $\begin{array}{l}V-191 \& \\
\text { V-193 }\end{array}$ & 135 & 148 & 70 & Yes \\
\hline $\begin{array}{l}\mathrm{V}-192 \text { \& } \\
\mathrm{V}-194\end{array}$ & 135 & 148 & 70 & Yes \\
\hline 1/4"-T035-316 & $5100^{(6)}$ & & - & \\
\hline 3/8"-T049-316 & $4800^{(6)}$ & & & \\
\hline 1/2”-T049-316 & $3700^{(6)}$ & & - & \\
\hline
\end{tabular}

(1) From CTI 12-631, unless otherwise noted.

(2) Maximum Allowable Working Pressure

(3) From Project Drawings: 782-4-100 through 782-4-190

(4) Note: additional pressure relief provided by PSV-4016 upstream DWG-782-4-140

(5) From Project Drawing: 782-4-160

(6) Swagelock Tubing Data (R10) accessed at

http://www.swagelok.com/downloads/WebCatalogs/EN/MS-01-107.PDF

\subsubsection{Reactor and Distillation Column Temperature Critical Controls}

The high-high temperature interlock $\left(500^{\circ} \mathrm{C}\right)$ for each of the eight zones of the R-130 vessel removes power to its respective heater. This eliminates the source of external heat to that zone and provides adequate margin below the vessel (shell) design temperature of $537^{\circ} \mathrm{C}$ (Table 4-2).

The high-high temperature interlocks $\left(425^{\circ} \mathrm{C}\right)$ remove power to the $\mathrm{V}-184$ distillation column reboiler and bottom section heaters to provide adequate margin below the vessel design temperature of $454^{\circ} \mathrm{C}$ (Table 4-2).

The ten (10) critical temperature controls (eight associated with R-130 and two associated with V-184) use safety circuitry, independent of the control circuitry, to fulfill their shutdown functions \{within the HTDC documentation (e.g., P\&IDs, Cause and Effect Diagram), TAHH-xxxxA denotes a control circuit; TAHH-xxxxB denotes a safety circuit\}. These safety and control circuits utilize independent 
thermocouples and PLCs to ensure safety system response is not compromised by failure of a control system. These temperature critical controls (designated as "P3" in the Supplemental HARs) receive their own credit in the quantitative risk assessment (see Appendices D and E).

\subsubsection{Enclosure Design and Ventilation}

The enclosure design and ventilation system reduce the potential for deflagrations resulting from the release of flammable vapors from the hydrotreater/distillation process pressure boundary.

Enclosure Design Class1 Division 2: All exposed electrical in the enclosure is Class 1 Division 2 (explosion proof) or contained in air purged cabinet (Z-Purge) to prevent the introduction of flammable vapors/gases. This minimizes the potential for an ignition source.

Enclosure Ventilation System: The enclosure is normally ventilated at 6 air changes per hour, which is consistent with standard laboratory flow rates at PNNL. The ventilation is well mixed due to the inlet being toward the bottom of the enclosure and the outlet near the top. This minimum ventilation rate meets the requirements of NFPA 55 and the IFC and reduces the concentration of flammable vapors to below lower flammability limits. Loss of enclosure ventilation shuts off the hydrogen supply and initiates Shutdown Scenario A (heaters, pumps, and hydrogen shutoff) from the hydrotreater/distillation column process controller (see Appendix B, “Key Design Information Reviewed,” - Interlock Matrices).

\subsubsection{Hydrogen Monitors}

There are three hydrogen monitors; one is installed high on the reactor skid and two are installed near the ceiling in the enclosure. The ceiling detectors alarm at $10 \%$ of the LEL resulting in a fire alarm control panel (FACP) supervisory alarm, and alarm at 25\% of the LEL which results in an FACP supervisory alarm, isolates the hydrogen supply, and initiates Shutdown Scenario A. The reactor skid detector is interlocked to isolate the hydrogen supply at 25\% of the LEL and also initiates Shutdown Scenario A.

\subsubsection{Flammable Vapor Monitors}

Flammable vapor monitors (one $\mathrm{H}_{2} \mathrm{~S}$ and two combustible gas detectors) are installed on the reactor and distillation skids. The $\mathrm{H}_{2} \mathrm{~S}$ detector alarms at $5 \mathrm{ppm}$ resulting in an FACP supervisory alarm, and alarms at $40 \mathrm{ppm}$ which results in an FACP supervisory alarm and initiates Shutdown Scenario B. The two combustible gas detectors alarm at $10 \%$ of the LEL and at $25 \%$ of the LEL initiate Shutdown Scenario A.

\subsubsection{Safe Operating Procedures (SOPs)}

The system will be operated via approved procedures. Per the SOPs:

- Trained operators: Each shift will have two operators (experienced with similar equipment) trained per the approved operating procedures. The system will not operate unattended.

- Pressure testing: Prior to the initiation of each run, the system is leak checked with nitrogen to ensure any re-assembly or cycling does not create a leak.

- System shutdown: This will ensure the system has been placed in a non-Class I/Div 2 status. 


\subsection{Other Controls (Non-Critical)}

This section describes the attributes of the other non-critical controls (Table 4-3) identified as providing significant benefit in further reducing the event frequency for higher consequence hazards associated with the hydrotreater/distillation column process as addressed in Section 3.4.

Table 4-3. Other Non-Critical Controls.

\begin{tabular}{|l|l|l|}
\hline \multicolumn{1}{|c|}{ Hazard Control } & Event Type & \multicolumn{1}{c|}{ Hazard ID } \\
\hline Flame Detectors & BLEVE & D.4-5; H.4-10; H.4-11; U-9; U-10; U-25 \\
\hline Fire Suppression System & BLEVE & D.4-5; H.4-10; H.4-11; U-9; U-10; U-25 \\
\hline Temperature and Pressure & BLEVE & $\begin{array}{l}\text { D.4-3; H.1-1; H.1-2; H.1-5; H.1-6; H.1-19; } \\
\text { Controls/Alarms Prompting Operator } \\
\text { Response }\end{array}$ \\
& & $\begin{array}{l}\text { H.2-10; H.2-15; H.2-20; H.3-6; H.4-2; H.4- } \\
\text { 6; H.4-7; H.7-1; H.7-7 }\end{array}$ \\
\cline { 2 - 3 } & PVB & H.4-17; H.4-27; U-1; U-7 \\
\hline Check Valves & PVB & H.4-1 \\
\hline Facility Configuration & FA & U-24; U-30 \\
\hline
\end{tabular}

\subsubsection{Flame Detectors}

There are two flame detectors located in the enclosure; activation of either results in the following:

- FACP alarm,

- Isolation of the hydrogen supply,

- Shutdown of the enclosure exhaust ventilation,

- Activation of the water mist system,

- Deactivation of power to the enclosure (after 5 second delay),

- Opening the reactor purge (vent) valve (after 60 second delay), and

- Initiation of Shutdown Scenario C.

\subsubsection{Fire Suppression System}

There are both sidewall wet-pipe sprinklers and a mist system located in the enclosure. The mist system is activated when the flame detector is activated.

\subsubsection{Temperature and Pressure Controls/Alarms Prompting Operator Response}

There are numerous high temperature and pressure alarm and control set points that provide the operator an opportunity to identify and correct an off-normal occurrence and to prevent/mitigate potential problems; many of these instruments will automatically control the system to limit potential problems in the unlikely event that prompt operator action is not taken. The high-high pressure interlocks (2700 psig) for the R-130 reactor vessel and the V-140 HP separator stop the flow of hydrogen and nitrogen and feed of bio-oil into the reactor. This eliminates the sources of pressure input and limits any exothermic reaction once the hydrogen is consumed thus protecting the pressure boundary of the reactor. These temperature and pressure alarms and controls would further reduce the frequency of a hazardous event. 


\subsubsection{Check Valves}

Check valves are in place throughout the hydrotreater system to protect against backflow.

\subsubsection{Facility Configuration}

The configuration of the facility housing the hydrotreater and distillation column skids will aid in ventilation of the system. PDL-West facility is equipped with a passive ventilation system. In the event of loss of enclosure ventilation, the large size of the PDL-West facility and passive ventilation system would further reduce the frequency of hazardous event scenarios.

\subsection{Safety Management Programs}

In addition to the critical controls described above, institutional Safety Management Programs (SMPs) are integrated into the PNNL requirements management infrastructure and delivered to staff members through the "How Do I...?” (HDI) work flows and work controls. HDI deploys the Laboratory-level requirements and procedures to PNNL staff. SMPs that are directly related to the Hydrotreater/Distillation project are identified below.

\subsubsection{Worker Safety and Health}

The Worker Safety and Health programs include the Chemical Hygiene Program, Hazard Communication Program, Hazard Assessment Program, Chemical Management System, and Integrated Safety Management System. Specific standards and procedures related to the operations of the hydrotreater/distillation project (Working with Chemicals, Compressed Gases, Pressure and Vacuum Systems, etc.) are provided in HDI, and implemented through Integrated Operations System (IOPS), and other implementing procedures.

IOPS helps managers and staff to identify and mitigate operational risks of experimental work in PNNLoperated workspaces. The processes involve identifying and managing risks and hazards associated with activities performed in each IOPS workspace, continually assessing ongoing or changing work risks, and controlling access so that only trained and authorized people are working in the workspace.

The IOPS tool delivers automated processes to support implementation of the IOPS program workflows that IOPS Administrators, Cognizant Space Managers, workers, and others use to achieve a safe workplace and efficient operations. The processes are designed to support the following:

- Configuration of IOPS buildings

- Establishing and maintaining IOPS workspaces

- Providing tailored controls

- Authorizing activities

- Performing work and monitoring work for changes.

\subsubsection{Fire Protection Program}

PNNL has established and maintains a Fire Protection Program that implements the applicable requirements of DOE O 420.1B, Facility Safety. This SMP applies to DOE facilities operated by PNNL 
including the PDL-West facility. The program affords a level of protection by providing the following services:

- Management of combustible materials and flammable liquids and gases

- A permit process for hot work

- $\quad$ Proper workspace housekeeping; facility and equipment modification design reviews and approvals; and periodic facility inspections and assessments

- Engineered features that minimize the potential for fire and the propagation of fires, including:

- Facility fire walls and barriers

- Fire detection and alarm systems

- Automatic suppression systems including the mist suppression system within the enclosure

- Portable fire extinguishers

- Emergency services (e.g., fire, medical) for PDL-West are provided by the City of Richland

- Implementation of applicable NFPA 101 requirements

- Inspection and maintenance of fire alarm, detection, and suppression systems

- Outages and impairments impacting fire protection systems are controlled and tracked through formal, documented systems to minimize the fire risks while systems are out of service.

The fire protection program is intended to ensure an available means of egress for personnel during a fire, minimize damage to property, and minimize the potential for DOE programs to suffer unacceptable delays or effects as a result of fire.

\subsubsection{Training and Qualification}

The training and qualification function establishes Laboratory-wide policies and standards and maintains a system for training delivery and documentation. Training and qualification requirements are implemented to ensure that personnel responsible for facility operations, process operations, vehicle operation, maintenance, and technical support are trained and qualified, as applicable, to accomplish their safety-related responsibilities. Line management makes sure that personnel are trained to work safely, effectively, and in accordance with DOE requirements and PNNL policies. PNNL training requirements and standards provide a uniform method for identifying, performing, and documenting the required indoctrination and training of PNNL staff.

\subsubsection{Maintenance and Testing Program}

This section discusses initial (startup) testing and maintenance programs for the PDL-West facility, including the Hydrotreater/Distillation Column project.

\subsubsection{Initial Testing}

PNNL facility design procedures require testing to verify proper operation of equipment and systems prior to their installation or return to service following facility modifications. Documents that implement installation and post-modification testing are developed based on operational and equipment functional requirements. Documents implementing installation, modifications, and associated tests 
(plans, permits, procedures, etc.) are prepared and peer reviewed by technical disciplines and linemanagement, as appropriate.

\subsubsection{Maintenance}

The PNNL facility operations function establishes a maintenance program that implements applicable maintenance requirements, including equipment vendor specifications and recommendations; and applicable national, state, local, and DOE codes and standards. PNNL facility procedures require testing to verify proper operation of specific safety equipment and systems (e.g., ventilation, cranes/hoists, fire alarm/detection/suppression) prior to returning them to service following preventive/corrective maintenance activities. Documents based on operational requirements; equipment functions; manufacture recommendations; operational restrictions; and/or applicable national, state, local, and DOE codes and standards implementing preventive/corrective maintenance actions and postmaintenance testing are prepared and peer reviewed by technical disciplines and line management, as appropriate. 


\subsection{CONCLUSION}

Two What-If hazard analyses were performed by PNNL to support the Hydrotreater/Distillation Process operation. These hazard analyses postulated off-normal or upset conditions including the release of the hazardous material or energy. For all events involving the release of material or energy, the hazard analyses identified the hazard controls which would prevent or mitigate the release. For high-energy events which could breach the hydrotreater and distillation column enclosure, the analyses were supplemented by calculations documenting the potential magnitude of the bounding case unmitigated consequences. The critical controls which are relied on to prevent the occurrence of these events are identified (see Table 4-1). Additional hazard controls identified for these events provide defense-indepth by reducing either the potential for or consequences of the postulated events (See Table 3-4, What-If Hazards Analysis Results). In addition, two supplemental hazard analyses were conducted and quantitative risk assessments performed for the Distillation Column and Hydrotreater units (see Appendices D and E).

With the identified hazard controls applied and operations performed within the envelope of the PNNL Safety Management Programs, the risks posed from operation of the hydrotreater and distillation columns are adequately mitigated, and these systems can be operated safely, consistent with PNNL control of other laboratory operations. 


\subsection{REFERENCES}

AIChE, 1992, Guidelines for Hazard Evaluation Procedures - With Worked Examples, $2^{\text {nd }}$ Edition, American Institute of Chemical Engineers, New York.

Casal, Joaquim and Salla, Josep, Using Superheating energy for a quick estimation of overpressures in BLEVEs and similar explosions, Journal of Hazardous Materials, A137, 2006 pp. 1321-1327

CCPS, 2000, Center for Chemical Process Safety, Guidelines for Chemical Process Quantitative Risk Analysis, American Institute of Chemical Engineers, New York.

CCPS, 2010, Center for Chemical Process Safety, Guidelines for Vapor Cloud Explosion, Pressure Vessel Burst, BLEVE and Flash Fire Hazards, American Institute of Chemical Engineers, New York

DOE-HDBK-1100-2004, Chemical Process Hazards Analysis, U.S. DOE

DOE/TIC-11268, A Manual for the Prediction of Blast and Fragment Loadings on Structures, Change 1, 15 August 1981, U.S. DOE Albuquerque Operations Office

CTI 12-631, Rev 2, Pressure Relief Vent Header and KO Vessel Sizing for PNNL Hydrotreater Facility, January 2013, Centaurus Technology Inc. Simpsonsville KY 40067

Lees’ Loss Prevention in the Process Industries. (Fourth Edition) Elsevier 2012, DOI: http://dx.doi.org/10.1016/B978-0-12-397189-0.00017-3

Louie, David L.Y. and Restrepo, Louis F., Analytical Approach for Gas Explosions for DOE Nuclear and Non-Nuclear Facilities. 
Hydrotreater/Distillation Column Hazard Analysis Report

\section{Appendix A: Attendees}

Page 88 of 98 


\section{Attendees}

\begin{tabular}{|l|l|l|l|}
\hline Name & Affiliation & Role \\
\hline Brawn & David & PNNL & Building Engineer \\
\hline Brooks & Shirley & PNNL & Hazards Analysis \\
\hline Carlson & Jeff & PNSO & \\
\hline Clark & Pat & PNNL & Facilities and Operations \\
\hline Coles & Garril & PNNL & Hazards Analysis \\
\hline Cuello & Rob & PNNL & Operations \\
\hline Dotson & Paul & PNNL & Facility PM \\
\hline Edwards & Dan & PNNL & ES\&H \\
\hline Elliot & Doug & PNNL & CBPDG \\
\hline Elliot & Mike & PNNL & \\
\hline Evans & Brad & PNNL & Nuclear Safety and Facility Authorization \\
\hline Hart & Todd & PNNL & Hydrotreater Project Operator \\
\hline Hastings & David & PNSO & \\
\hline Lowry & Pete & PNNL & Hazards Analysis \\
\hline McGaughy & Renee & PNNL & WS\&H \\
\hline McMullin & Ken & PNNL & Building Manager \\
\hline Minister & Andrew & PNNL & Fire Protection \\
\hline Neuenschwander & Gary & PNNL & Hydrotreater Project Operator \\
\hline Olarte & Mariefel V & PNNL & Hydrotreater Project Operator \\
\hline Orth & Rick & PNNL & Line Manager \\
\hline Paulsen & Sam & PNNL & Pressure Safety \\
\hline Rohrig & David & PNNL & ES\&H - Pressure Safety \\
\hline Rotness & L.J. & PNNL & Hydrotreater Project Operator \\
\hline Sauve & Gerald & PNSO & \\
\hline Short & Steve & PNNL & Hazards Analysis \\
\hline Stephens & Vicki & PNNL & Operations \\
\hline Wagner & Dan & PNNL & Building Engineer \\
\hline Wyatt & Vavid & PNNL & WS\&H - Fire Protection \\
\hline Xuan & Alan & PNSO & \\
\hline Zacher & PNNL & Hydrotreater Project-PM \\
\hline & & & \\
\hline
\end{tabular}

Note: Personnel who attended 1 or more meetings. 


\section{Appendix B: Key Design Information Reviewed}




\section{Design Information Reviewed}

\section{HYDROTREATER/DISTILLATION SYSTEM Calculations}

CTI 12-631, Rev 2, Pressure Relief Vent Header and KO Vessel Sizing for PNNL Hydrotreater Facility

HYDROTREATER/DISTILLATION SYSTEM Drawings ${ }^{3}$
\begin{tabular}{|l|l|}
\hline PNNL HYDROTREATER - DISTILLATION PROCESS SKETCH & \\
\hline 782-4-100 PNNL BIO-OIL HYDROTREATER BIO-OIL BATCH FILTRATION & \\
\hline 782-4-110 PNNL BIO-OIL HYDROTREATER GAS FEED & \\
\hline 782-4-120 PNNL BIO-OIL HYDROTREATER LIQUID FEED & \\
\hline 782-4-130 PNNL BIO-OIL HYDROTREATER REACTf & \\
\hline 782-4-140 PNNL BIO-OIL HYDROTREATER GAS/OIL/WATER SEPARATION \\
\hline 782-4-150 PNNL BIO-OIL HYDROTREATER PRODUCT GAS MEASUREMENT \\
\hline 782-4-160 PNNL BIO-OIL HYDROTREATER LIQUID PRODUCT COLLECTION \\
\hline 782-4-170 PNNL BIO-OIL HYDROTREATER WATER RECIRCULATION \\
\hline 782-4-180 PNNL BIO-OIL DISTILLATION COLUMN \\
\hline 782-4-190 PNNL BIO-OIL DISTILLATION COLUMN CUT COLLECTION \\
\hline
\end{tabular}

ENCLOSURE/FACILITY Drawings ${ }^{3}$

\begin{tabular}{|c|c|}
\hline A2.0 PNNL HYDROTREATER ENCLOSURE DESIGN PDLW FLOOR PLAN &  \\
\hline A3.1 PNNL HYDROTREATER ENCLOSURE DESIGN Exterior Elevations PLAN & $\begin{array}{l}\text { A3.1_Hydrotreater - } \\
\text { Enclosure. pdf }\end{array}$ \\
\hline M2.0 PNNL HYDROTREATER ENCLOSURE - Enclosure P\&ID & $\begin{array}{l}\text { M2.0 Enclosure } \\
\text { P\&ID. pdf }\end{array}$ \\
\hline M2.1 PNNL HYDROTREATER ENCLOSURE - Enclosure P\&ID & $\begin{array}{l}\text { M2.1 Enclosure } \\
\text { P\&ID. pdf }\end{array}$ \\
\hline M2.3 PNNL HYDROTREATER ENCLOSURE - Enclosure P\&ID & $\begin{array}{l}\text { M2.3 Enclosure } \\
\text { P\&ID. pdf }\end{array}$ \\
\hline
\end{tabular}

\footnotetext{
${ }^{3}$ These drawings are historical documents and subject to change. See the Hydrotreater/Distillation Column SharePoint site for current drawings.
} 
Hydrotreater/Distillation Column Hazard Analysis Report

INTERLOCK MATRICES ${ }^{4}$

\begin{tabular}{|l|c|}
\hline Cause/Effect Matrix & $\begin{array}{c}\text { Cause and Effect } \\
\text { Rev 2_24j an_2013_F }\end{array}$ \\
\hline FACP Hydrotreater Logic & $\begin{array}{c}\text { Por } \\
\text { 3030 } \\
\text { Logic-Hydotreater-Rz }\end{array}$ \\
\hline
\end{tabular}

${ }^{4}$ These documents are historical and subject to change. See the Hydrotreater/Distillation Column SharePoint Site for current versions. 


\section{Appendix C: November 2012 Hydrotreater / Distillation Column Project Hazard and Risk Analysis Report}


Hydrotreater/Distillation Column Hazard Analysis Report

November 2012 Hydrotreater / Distillation Column Project Hazard and Risk Analysis Report

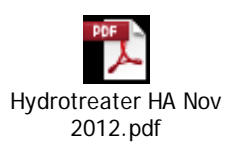

Page 94 of 98 


\section{Appendix D: Supplemental Hazard Analysis and Risk Assessment - Distillation Column}


Hydrotreater/Distillation Column Hazard Analysis Report

Supplemental Hazard Analysis and Risk Assessment - Distillation Column

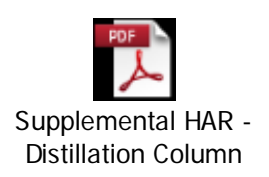

Page 96 of 98 


\section{Appendix E: Supplemental Hazard Analysis and Risk Assessment - Hydrotreater}


Hydrotreater/Distillation Column Hazard Analysis Report

Supplemental Hazard Analysis and Risk Assessment - Hydrotreater

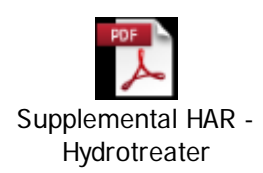

Page 98 of 98 


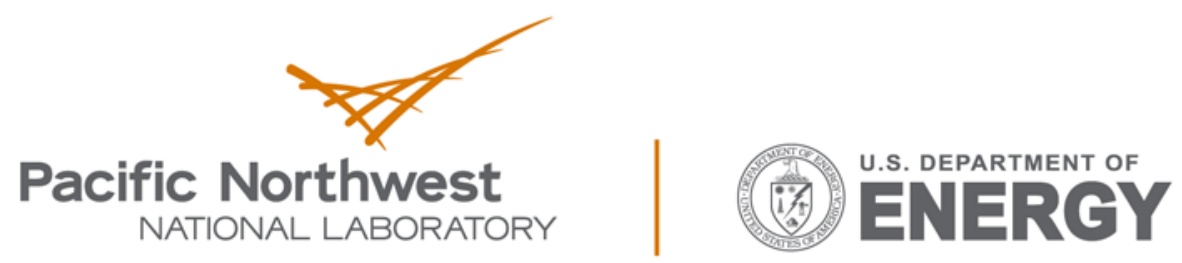

Proudly Operated by Battelle Since 1965

902 Battelle Boulevard

P.O. Box 999

Richland, WA 99352

1-888-375-PNNL (7665)

www.pnnl.gov 